\title{
1999 ENVIRONMENTAL MONITORING REPORT
}

\author{
for the
}

\section{BETTIS ATOMIC POWER LABORATORY PITTSBURGH SITE}

PREPARED FOR THE U.S. DEPARTMENT OF ENERGY BY BECHTEL BETTIS, INC.

WEST MIFFLIN, PENNSYLVANIA 15122-0079

DOCUMENT NUMBER: B-RC/E(EE)EMR-0700 
This page intentionally left blank 


\section{DISCLAIMER}

This report was prepared as an account of work sponsored by an agency of the United States Government. Neither the United States Government nor any agency thereof, nor any of their employees, make any warranty, express or implied, or assumes any legal liability or responsibility for the accuracy, completeness, or usefulness of any information, apparatus, product, or process disclosed, or represents that its use would not infringe privately owned rights. Reference herein to any specific commercial product, process, or service by trade name, trademark, manufacturer, or otherwise does not necessarily constitute or imply its endorsement, recommendation, or favoring by the United States Government or any agency thereof. The views and opinions of authors expressed herein do not necessarily state or reflect those of the United States Government or any agency thereof. 


\section{DISCLAIMER}

Portions of this document may be illegible in electronic image products. Images are produced from the best available original document. 


\section{TABLE OF CONTENTS}

Table of Contents .....................................................................................

List of Tables ............................................................................................. iii

List of Figures..................................................................................... iv

List of Acronyms/Other Common Abbreviations ........................................ v

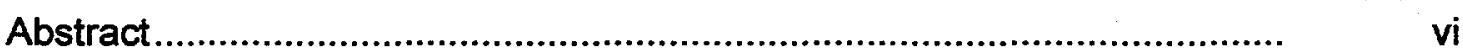

Executive Summary ................................................................................

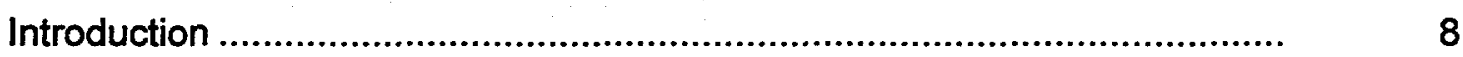

Site Background and Environmental Setting............................................... 9

Environmental Monitoring Programs.......................................................... 16

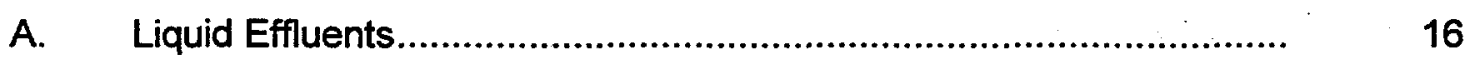

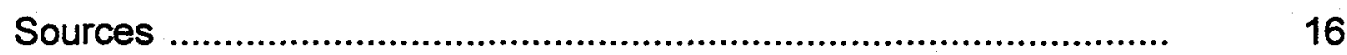

Liquid Monitoring ............................................................................ 16

Liquid Analyses ...................................................................... 18

Liquid Monitoring Results and Conclusions ..................................... 19

B. Ground Water....................................................................... 25

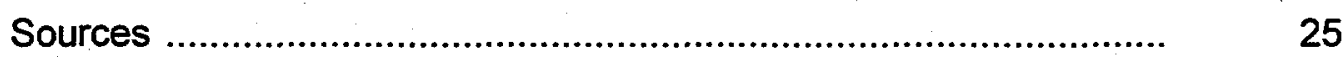

Ground Water Monitoring .......................................................... . $\quad 25$

Ground Water Analyses .............................................................. 27

Ground Water Monitoring Results and Conclusions ......................... $\quad 27$

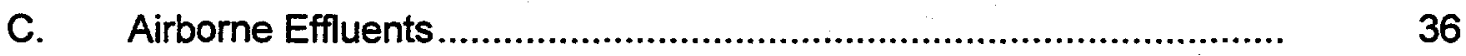

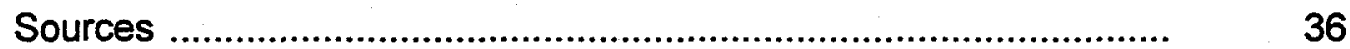

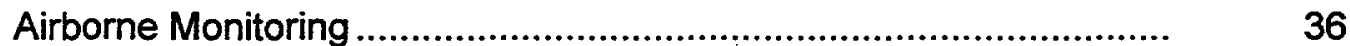

Airborne Analyses …................................................................. 37

Airborne Monitoring Results and Conclusions ................................. $\quad 37$

D. Sediment, Soil, and Vegetation .................................................... 40

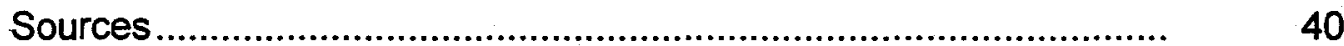

Sediment, Soil, and Vegetation Monitoring ..................................... $\quad 40$

Sediment, Soil, and Vegetation Analyses ....................................... 42

Sediment, Soil, and Vegetation Monitoring 


\section{TABLE OF CONTENTS (Continued)}

E. Radiation Monitoring ................................................................ 47

Radiation Sources...................................................................... 47

Radiation Monitoring ............................................................. 47

Radiation Analyses.............................................................. 47

Radiation Monitoring Results and Conclusions................................. $\quad 47$

Control of Chemical and Hazardous Wastes .............................................. 50

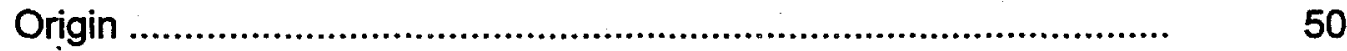

Control Program ........................................................................ 50

Disposal ................................................................................ 50

Control of Radioactive Wastes ..................................................................

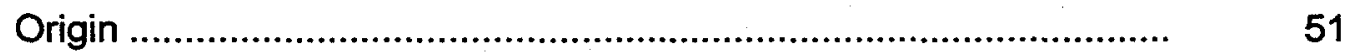

Control Program ........................................................................ 51

Disposal/Treatment/Recycling ....................................................... . 51

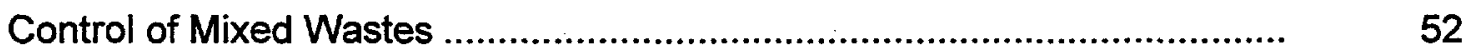

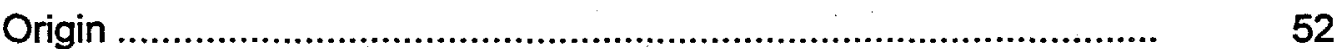

Control Program ............................................................................. 52

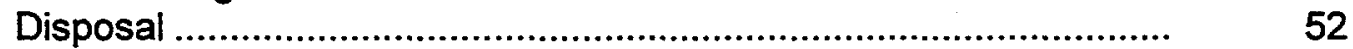

Environmental Monitoring Quality Assurance ............................................ 53

General Quality Assurance Controls............................................... 53

Radiological Quality Assurance Controls ......................................... 53

Nonradiological Quality Assurance Controls..................................... 53

Assessment of Risk from Chemical Residues .............................................. 54

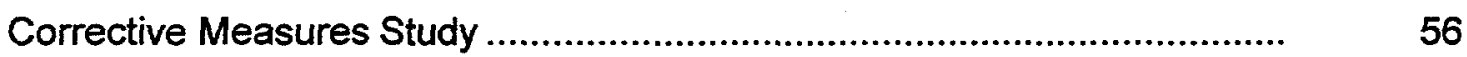

Assessment of Radiation Dose-to-Man .................................................... 58

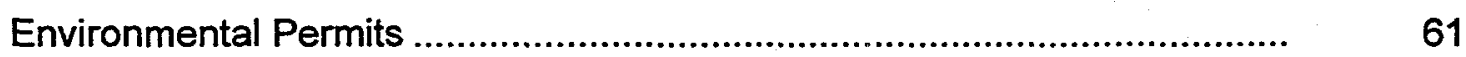

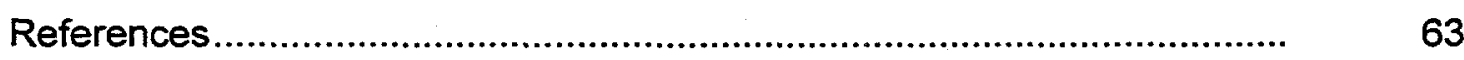

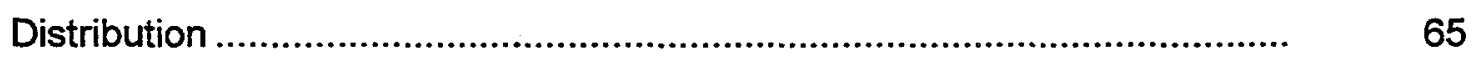

Appendix A USDOE/EML Radioanalytical Quality Assurance Results 


\section{LIST OF TABLES}

Table

Number

Table 1 Radiological Environmental Monitoring Program

Title

Page

Table 2 Nonradiological Environmental Monitoring Program.

3

Table 3 Generalized Section of Rock Strata Beneath

the Bettis Laboratory

Table $4 \quad$ Liquid Influent and Effluent Radioactivity Results 20

Table 5 Summary of NPDES Permit Sample Analysis Results 22

Table 6 Summary of Semimonthly and Semiannual Influent and Effluent Water Quality Results

Table 7 Annual Influent and Effluent Water Quality Results

Table 8A-8F Ground Water Radioactivity Results........................................... 29

Table 9A-9B Ground Water Nonradiological Results ...................................... 34

Table 10 Airborne Effluent Radioactivity Results .......................................... 38

Table 11 Storm Drain and Stream Sediment Radioactivity Results ................... 43

Table 12 Stream Vegetation Radioactivity Results ....................................... 43

Table 13 Duquesne Light Soil Radiological Results ........................................ 44

Table 14 Duquesne Light and Valley National Gases, Inc. Soil Nonradiological Results

Table 15 Storm Drain and Stream Sediment Nonradiological Results................ 46

Table 16 Thermoluminescent Dosimeter (TLD) Environmental Radiation Results

Table 17 Radiation Dose-to-Man from Site Operations 59

Table 18 Environmental Permits. 61 
Bettis-Pittsburgh 1999 Environmental Monitoring Report

LIST OF FIGURES

Figure

Number

Figure 1 Relationship of the Betti Site to the Surrounding Communities

Figure 2 Land Uses Immediately Adjacent to the Bettis Site

Figure 3 Aerial View of the Developed Portion of the Betti Laboratory

Figure 4 Liquid Effluent Monitoring Locations

Figure 5 Locations of Wells and Springs
Page

10

11

12

17

26

Figure 6 Soil and Surface Water Sample Locations on the Inactive Waste Site, and on Duquesne Light and Valley National Gases Incorporated Properties... 33

Figure 7 Sediment and Vegetation Monitoring Locations

41

Figure 8 Radiation Monitoring Locations

48

iv 


\section{LIST OF ACRONYMS}

CERCLA

CMS

DCE

$\mathrm{DL}$

DOE

EPA

HEPA

MDL

MEL

NPDES

NRC

PADEP

PASI

PAH

PCB

PCE

RCRA

RFI

SIS

TCE

TLD

VOC

VNGI

$\mu \mathrm{Ci}$

$\mu \mathrm{Ci} / \mathrm{ml}$

$\mu g / l$

$\mathrm{mg} / \mathrm{l}$

mrem

$\mathrm{ml}$

$\mathrm{mg} / \mathrm{kg}$

$\mathrm{pCi}$

$\mathrm{pCi} / \mathrm{g}$

pCi/l
Comprehensive Environmental Response, Compensation and Liability Act

Corrective Measures Study

1,2-Dichloroethylene

Duquesne Light

U.S. Department of Energy

U.S. Environmental Protection Agency

High Efficiency Particulate Air

Minimum Detection Level

Materials Evaluation Laboratory

National Pollutant Discharge Elimination System

Nuclear Regulatory Commission

Pennsylvania Department of Environmental Protection

Preliminary Assessment and Site Inspection

Polynuclear Aromatic Hydrocarbon

Polychlorinated Biphenyls

Tetrachloroethylene (Perchloroethylene)

Resource Conservation and Recovery Act

RCRA Facility Investigation

Springwater Intercept System

Trichloroethylene

Thermoluminescent Dosimeters

Volatile Organic Compound

Valley National Gases Incorporated

\section{OTHER COMMON ABBREVIATIONS}

microcurie $=1 \times 10^{-6}$ curie

microcuries per milliliter

micrograms per liter

milligrams per liter

millirem

milliliter

milligrams per kilogram

picocurie $=1 \times 10^{-12}$ curie

picocuries per gram

picocuries per liter 


\section{ABSTRACT}

The 1999 results for the Bettis-Pittsburgh radiological and nonradiological environmental monitoring programs are presented. The results demonstrate that the existing procedures ensured that releases to the environment during 1999 were in accordance with applicable Federal, State, County, and local regulations. Evaluation of the environmental data indicates that current operations at the Site continue to have no adverse effect on human health and the quality of the environment.

A conservative assessment of radiation exposure to the general public as a result of Site operations demonstrates that the dose received by any member of the public was well below the most restrictive dose limits established by the Environmental Protection Agency, the Nuclear Regulatory Commission, and the U.S. Department of Energy.

A risk assessment of potentially exposed populations to chemical residues in the environment at the Site demonstrates that these residues do not pose any significant risk to human health or the environment. 


\section{EXECUTIVE SUMMARY}

The results of the 1999 radiological and nonradiological environmental monitoring programs for the Bettis Atomic Power Laboratory-Pittsburgh Site are summarized below. Tables 1 and 2 summarize the major elements of the environmental monitoring programs.

\section{Liquid Effluents (Other than to Sanitary Sewer)}

Approximately $48,900,000$ gallons of noncontact cooling water, process waste water, and storm runoff were released to the environment via the Bull Run (Outfall 001) and Northeast Area (Outfall 002) Monitoring Stations. Radioactivity attributed to Site operations was not detected in any of the samples of these releases. Radioactivity concentrations were either below minimum detection levels or were typical of background levels in city water and precipitation. Monitoring data for chemical constituents in liquid effluents demonstrated that these effluents did not have any significant impact on the quality of the receiving water. These results demonstrated compliance with the U. S. Department of Energy (DOE) standards and the Site's National Pollutant Discharge Elimination System (NPDES) Permit.

Storm water runoff via Storm Water Outfalls 003, 004, 005 and 006 and treated ground water via Outfall 007 was released to the environment in accordance with the Site's NPDES Permit.

\section{Sanitary Sewer Discharges}

Sanitary sewage was discharged to a Publicly Owned Treatment Works. Wastes discharged to the sanitary system were in compliance with applicable regulations.

Radioactivity attributable to Site operations was not detected in any of the samples of processed ground water which was discharged to the sanitary sewer system.

\section{Ground Water}

Analyses of the vast majority of ground water samples from five water-bearing zones beneath the Site did not detect any radioactivity in excess of natural background. Very small portions of the Perched Water-Bearing Zone contained low levels of strontium-90 due to small inadvertent releases in the 1950 s and 1960s. In addition, strontium-90 was detected in the Pittsburgh Coal Water-Bearing Zone at levels near background strontium-90 levels from past atmospheric nuclear weapons testing. The levels of strontium-90 were well below the 10 CFR 20 limits for water in unrestricted areas and below the 40 CFR 141 limits for drinking water.

The results of the majority of the ground water analyses for a variety of chemicals were less than minimum detection levels. Some analyses indicated the presence of volatile organic compounds, primarily tetrachloroethylene, which are associated with past degreasing operations at Bettis and possibly by prior tenants when the Site was an airfield. The presence of these chemicals is not due to current Site operations.

Some of the water that seeps out of the hillside on the Inactive Waste Site and on Duquesne Light and Valley National Gases Inc. properties below the Inactive Waste Site contains low levels of Bettis radioactivity, primarily strontium-90 and uranium. The concentrations of these materials are consistent with previous levels and are below the 10 CFR 20 limits for water in unrestricted areas. The strontium-90 level is also below the 40 CFR 141 limit for drinking water; there is no current limit for uranium in drinking water. 
TABLE 1

\begin{tabular}{|c|c|c|}
\hline \multicolumn{3}{|c|}{ RADIOLOGICAL ENVIRONMENTAL MONITORING PROGRAM ${ }^{(1)}$} \\
\hline MEDIA MONITORED & ANALYSIS FREQUENCY & ROUTINE ANALYSES \\
\hline \multirow{2}{*}{$\begin{array}{l}\text { LIQUID EFFLUENTS } \\
\text { - Bull Run Monitoring Station } \\
\text { - Northeast Area Monitoring } \\
\text { Station } \\
\text { - Sanitary Sewer (SAN2) } \\
\end{array}$} & Weekly & Gross Alpha, Gross Beta \\
\hline & Quarterly & Strontium-90, Gamma \\
\hline - Sanitary Sewer (SAN10) & Semiannually & Gross Alpha, Gross Beta \\
\hline \multirow{2}{*}{$\begin{array}{l}\text { LIQUID INFLUENTS } \\
\text { - City Water } \\
\text { - Precipitation } \\
\end{array}$} & Weekly & Gross Alpha, Gross Beta \\
\hline & Quarterly & Strontium-90, Gamma \\
\hline $\begin{array}{l}\text { GROUND WATER } \\
\text { - Wells } \\
\text { - Inactive Waste Site Seepage } \\
\text { SURFACE WATER } \\
\text { - Bull Run Stream (BR5) }\end{array}$ & Annually & $\begin{array}{c}\text { Gross Alpha, Gross Beta, } \\
\text { Strontium-90, Gamma, } \\
\text { Uranium-233/234, Uranium-235, } \\
\text { Uranium-238 }\end{array}$ \\
\hline \multirow{3}{*}{$\begin{array}{l}\text { STREAM SEDIMENT AND } \\
\text { VEGETATION } \\
\text { - Bull Run Stream } \\
\text { - Northeast Area Stream } \\
\text { - Thompson Run Stream } \\
\text { - Streets Run Stream (Control) }\end{array}$} & $\begin{array}{l}\text { Semiannually } \\
\text { (Sediment) }\end{array}$ & Gross Alpha, Gross Beta, Gamma \\
\hline & $\begin{array}{c}\text { Annually } \\
\text { (Sediment) }\end{array}$ & $\begin{array}{l}\text { Strontium-90 (Bull Run and Streets } \\
\text { Run Streams only) }\end{array}$ \\
\hline & $\begin{array}{l}\text { Annually } \\
\text { Negetation) }\end{array}$ & Strontium-90, Gamma \\
\hline $\begin{array}{l}\text { SEDIMENT } \\
\text { - Bull Run Monitoring Station } \\
\text { - Northeast Area Monitoring } \\
\text { Station } \\
\text { - Storm Drain Components }\end{array}$ & Annually & Gross Alpha, Gross Beta, Gamma \\
\hline $\begin{array}{l}\text { SOIL } \\
\text { - Duquesne Light/Nalley National } \\
\text { Gases Inc. }\end{array}$ & Every Two Years $(2000)^{(2)}$ & $\begin{array}{c}\text { Gross Alpha, Gross Beta, } \\
\text { Strontium-90, Gamma, } \\
\text { Uranium-233/234, Uranium-235, } \\
\text { Uranium-238 }\end{array}$ \\
\hline $\begin{array}{l}\text { RADIATION } \\
\text { - Site Perimeter }\end{array}$ & Continuously & \multirow{3}{*}{ Gamma Radiation } \\
\hline - Bull Run Stream & Every Fifth Year (2001) ${ }^{(2)}$ & \\
\hline $\begin{array}{l}\text { - Duquesne Light/Valley National } \\
\text { Gases Inc. }\end{array}$ & Every Two Years $(2000)^{(2)}$ & \\
\hline \multirow{2}{*}{$\begin{array}{l}\text { AIRBORNE EFFLUENT } \\
\text { - Particulate Activity }\end{array}$} & Weekly & Gross Alpha, Gross Beta \\
\hline & Quarterly & $\begin{array}{l}\text { Gross Alpha, Gross Beta } \\
\text { Strontium-90, Gamma }\end{array}$ \\
\hline - Gaseous Activity & Quarterly & Gamma Radiation \\
\hline - Radon & Annually & Radon-220, Radon-222 \\
\hline $\begin{array}{l}\text { AIRBORNE } \\
\text { (Ambient Background) } \\
\text { - Large, PA } \\
\text { - West Mifflin, PA }\end{array}$ & Weekly & Gross Alpha, Gross Beta \\
\hline
\end{tabular}

NOTES: (1) The monitoring methods used in this program are "grab and composite" sampling.

(2) Indicates year when sampling/monitoring is next due to occur. 
TABLE 2

\begin{tabular}{|c|c|c|}
\hline \multicolumn{3}{|c|}{ NONRADIOLOGICAL ENVIRONMENTAL MONITORING PROGRAM(ग) } \\
\hline MEDIA MONITORED & $\begin{array}{l}\text { ANALYSIS } \\
\text { FREQUENCY }\end{array}$ & ROUTINE ANALYSES \\
\hline \multirow{3}{*}{$\begin{array}{l}\text { LIQUID EFFLUENTS } \\
\text { - Bull Run Monitoring Station } \\
\text { - Northeast Area Monitoring Station }\end{array}$} & Semimonthly & $\begin{array}{l}\text { Dissolved oxygen, fecal coliforms, oil and grease, pH, suspended } \\
\text { solids, temperature. }\end{array}$ \\
\hline & Semiannually & $\begin{array}{l}\text { Alkalinity, aluminum, ammonia, chloride, color, fluoride, } \\
\text { hardness, iron (dissolved), iron (total), manganese, nitrate, nitrite, } \\
\text { osmotic pressure, phenols, sulfate, methylene blue active } \\
\text { substance, total dissolved solids, threshold odor, turbidity. }\end{array}$ \\
\hline & Annually & $\begin{array}{l}\text { Antimony, arsenic, base neutralacids, beryllium, cadmium, } \\
\text { chromium (hexavalent), chromium (total), copper, cyanide (free), } \\
\text { lead, mercury, nickel, pesticides, polychlorinated biphenyls, } \\
\text { selenium, silver, thallium, volatile organic compounds, zinc. }\end{array}$ \\
\hline $\begin{array}{l}\text { - Bull Run Outfall (001) } \\
\text { - Storm Water Outfall } 003 \\
\text { - Storm Water Outfall } 004 \\
\text { - Storm Water Outfall } 005 \\
\text { - Storm Water Outfall } 006\end{array}$ & Quarterly & Fecal coliforms, aluminum (Outfalls 004 and 005 only) \\
\hline - SIS Outfall 007 & Semimonthly & $\begin{array}{l}\text { Iron (dissolved), pH, suspended solids, tetrachloroethylene, } \\
\text { trichloroethylene, 1,2-dichloroethylene }\end{array}$ \\
\hline \multirow{2}{*}{$\begin{array}{l}\text { - Sanitary Sewer } \\
\text { (SAN-10) }\end{array}$} & Semiannually & $\begin{array}{l}\text { Biochemical oxygen demand, dissolved oxygen, oil and grease, } \\
\mathrm{pH} \text {, temperature. }\end{array}$ \\
\hline & Annually & $\begin{array}{l}\text { Chromium (hexavalent), chromium (total), cyanide (free), lead, } \\
\text { mercury, silver. }\end{array}$ \\
\hline \multirow[t]{3}{*}{$\begin{array}{l}\text { LIQUID INFLUENTS } \\
\text { - City Water }\end{array}$} & Semimonthly & $\begin{array}{l}\text { Dissolved oxygen, fecal coliforms, oil and grease, } \mathrm{pH} \text {, suspended } \\
\text { solids, temperature. }\end{array}$ \\
\hline & Semiannually & $\begin{array}{l}\text { Alkalinity, aluminum, ammonia, chloride, color, fluoride, } \\
\text { hardness, iron (dissolved), iron (total), manganese, nitrate, nitrite, } \\
\text { osmotic pressure, phenols, sulfate, methylene blue active } \\
\text { substance, total dissolved solids, threshold odor, turbidity. }\end{array}$ \\
\hline & Annually & $\begin{array}{l}\text { Antimony, arsenic, polynuclear aromatic hydrocarbons, beryllium, } \\
\text { cadmium, chromium (hexavalent), chromium (total), copper, } \\
\text { cyanide (free), lead, mercury, nickel, pesticides, polychlorinated } \\
\text { biphenyls, selenium, siver, thallium, volatile organic compounds, } \\
\text { zinc. }\end{array}$ \\
\hline \multirow{2}{*}{$\begin{array}{l}\text { GROUND WATER } \\
\text { - Wells } \\
\text { - Inactive Waste Site Seepage }\end{array}$} & Annually & $\begin{array}{l}\text { Volatile organic compounds } \\
\text { Polychlorinated biphenyls and polynuclear aromatic } \\
\text { hydrocarbons (Inactive Waste Site Seepage Only) }\end{array}$ \\
\hline & $\begin{array}{l}\text { Every Three } \\
\text { Years }(2001)^{(2)}\end{array}$ & $\begin{array}{l}\text { Antimony, arsenic, barium, beryllium, cadmium, chromium, } \\
\text { copper, iron, lead, manganese, mercury, nickel, selenium, silver, } \\
\text { sodium, thallium, zinc, chloride, fluoride, nitrate, sulfate, sulfide, } \\
\text { cyanide, polynuclear aromatic hydrocarbons, phenol, and } \\
\text { suspended solids (Wells only) }\end{array}$ \\
\hline $\begin{array}{l}\text { SEDIMENT } \\
\text { - Bull Run Monitoring Station } \\
\text { - Northeast Area Monitoring Station } \\
\text { - Storm Drain Components }\end{array}$ & Annually & $\begin{array}{l}\text { Polychlorinated biphenyls, volatile organic compounds, total } \\
\text { mercury. }\end{array}$ \\
\hline $\begin{array}{l}\text { - Bull Run Stream } \\
\text { (BR1, BR5) }\end{array}$ & Annually & Volatile organic compounds \\
\hline $\begin{array}{l}\text { SOIL } \\
\text { - Duquesne Light/Valley National } \\
\text { Gases, Inc. }\end{array}$ & Annually & $\begin{array}{l}\text { Polychlorinated biphenyis, volatile organic compounds, } \\
\text { polynuclear aromatic hydrocarbons. }\end{array}$ \\
\hline $\begin{array}{l}\text { SURFACE Water } \\
\text { - Bull Run Stream (BR1, BR5). }\end{array}$ & Annually & Volatile organic compounds. \\
\hline
\end{tabular}

NOTES: (1) The monitoring method used in this program is "grab" sampling except for suspended solids sampling at the Bull Run and Northeast Area Monitoring Stations. These samples were collected as composite samples over a 24-hour period.

(2) Indicates year when sampling/monitoring is next due to occur. 
Analyses of the seepage below the Inactive Waste Site on Duquesne Light and Valley National Gases Inc. properties for volatile organic compounds show the presence of low levels of tetrachloroethylene, trichloroethylene and dichloroethylene. The concentrations of these materials are consistent with concentrations previously observed and reported.

\section{Sediment, Soil, and Vegetation}

Analyses for radioactivity in the Site's effluent streambeds demonstrated that there were no measurable changes in the low levels of radioactivity, from historical operations, in the streambeds during 1999.

Analyses of vegetation collected in and along the Site's effluent streams did not detect any radioactivity in excess of natural background levels.

Analyses for a variety of chemicals in the soil in and below the main drainage area that is down slope of the Inactive Waste Site on portions of Duquesne Light and Valley National Gases properties typically showed the presence of low levels of Program residues, primarily tetrachloroethylene and polychlorinated biphenyls. The levels of these materials were consistent with previous levels and indicate that there has not been any build-up in this area in the last several years.

Analyses for radioactivity in the soil of a secondary drainage area, identified in 1999, below the Inactive Waste Site on Duquesne Light property showed the presence of low levels of radioactivity, primarily cesium-137. The radioactivity levels were consistent with background as well as levels in the main drainage ditch.

Analyses for chemicals in the secondary drainage ditch did not show the presence of the volatile organic compounds that are in the main drainage ditch. Also, trace amounts of polychlorinated biphenyls were detected in three of the six samples. Several polynuclear aromatic hydrocarbons (PAH) were detected in the soil samples at concentrations consistent with anthropogenic background PAH compounds in the vicinity of the Site.

Analyses for a variety of chemicais in the storm drain sediment showed the presence of low leveis of tetrachloroethylene, polychlorinated biphenyls and mercury in some samples. The levels were consistent with previous results. Analyses for a variety of chemicals in the Bull Run stream sediment show the presence of low levels of tetrachloroethylene and polychlorinated biphenyls. The levels were consistent with previous results.

\section{Radiation}

Radiation surveys of the Site perimeter demonstrated that radiation levels were typical of background radiation levels for Western Pennsylvania. Perimeter thermoluminescent dosimetry data also confirmed that Site operations did not cause any measurable change in the natural radiation environment surrounding the Site.

\section{Airborne Effluents}

Radioactivity in Site airborne effluents was controlled using high efficiency particulate filters, wet scrubbing systems and, in some cases, charcoal filters to maintain particulate and gaseous radioactivity releases to as-low-as-reasonably-achievable. The amount of long-lived ( $>1$ day half-life) particulate radioactivity released in airborne effluents was approximately 0.00000167 Curie in 1999 . Comparison of the Site's airborne effluents with background air samples showed that the Site's 
airborne particulate effluent was up to nine times lower than natural background airborne particulate radioactivity. There were no long-lived gaseous radioactivity releases in 1999.

Nonradiological constituents in Site emissions for Site fuel combustion and heating units were estimated utilizing U.S. Environmental Protection Agency (EPA) emission factors and were well below applicable EPA and Allegheny County standards. Operation of the Site's fuel combustion and heating equipment was conducted in accordance with the Site's Air Operating Permit application.

\section{Risk Assessment}

A risk assessment was approved by the EPA in 1994 as part of the Site's Resource Conservation and Recovery Act (RCRA) Facility Investigation. The assessment determined the "reasonable maximum exposure" of on-site and off-site populations to chemical residues in the environment at the Site.

The assessment concluded that chemical residues in the environment at the Site did not pose significant health risks to potentially exposed populations using "reasonable maximum exposure" assumptions. The only study area where the carcinogenic risk estimate exceeded the EPA comparison criterion of $1 \times 10^{-6}(0.000001)$ is a small area of soil on a remote portion of Duquesne Light (DL) and Valley National Gases Incorporated (VNGI) properties, with a maximum carcinogenic risk of about $2 \times 10^{-5}(0.00002)$. However, an individual must be exposed (skin contact, ingestion, and inhalation) for 250 days/year for 25 years to achieve this risk. This risk is highly conservative because the contaminated portions of DL and VNGI properties are in infrequently accessed or undeveloped locations. In reality, the risk of personnel exposure to the chemical residues is far less than $1 \times 10^{-6}$.

The 1999 monitoring results support the conclusions of the 1994 risk assessment.

\section{Dose-to-Man}

Radiation exposure to the general public from Site airborne releases was too low to measure and could only be estimated using conservative, EPA authorized calculational models. The resultant evaluation of all exposure pathways conservatively estimated a maximum annual hypothetical dose range of 0.28 to 2.6 millirem to an individual off-site. Realistically, the actual maximum annual dose would approach 0.28 millirem. However, using the larger value of 2.6 millirem, the dose is only $2.6 \%$ of the numerical limit established for members of the general public by the Nuclear Regulatory Commission and the DOE for DOE facilities such as Bettis-Pittsburgh. The annual dose to the population from Site operations within a 50-mile radius of the Site was conservatively estimated to be about 1.46 man-rem which is negligible when compared to the approximately 900,000 man-rem received by this population from natural background radiation.

\section{Chemical and Hazardous Waste}

A waste minimization program is in place to minimize the generation of chemical and hazardous wastes. These wastes were handled, controlled, and stored by trained personnel in accordance with applicable State regulations and permits. In addition, these wastes were not disposed of on the Site. Approximately 48,670 pounds of hazardous wastes were generated and packaged for off-site disposal by waste vendors. These vendors operate under Federal and State permits. Approximately 99,033 gallons of processed ground water and water from sampling, containing traces (less than one ounce total) of a few volatile organic compounds, were discharged to the sanitary sewer system in accordance with Federal, State, and local regulations. 


\section{Radioactive Waste}

The generation of low-level radioactive waste continues to be minimized by limiting the materials that could become contaminated and by implementing various waste volume reduction techniques. Radioactive waste generated on-site is shipped off-site for disposal. A total of 278 cubic meters of the low-level radioactive waste generated on-site during 1999 were packaged in various type containers which comply with U. S. Department of Transportation specifications, and shipped to a DOE-owned disposal facility. When necessary, small amounts of radioactive liquids were solidified prior to shipment off-site for disposal. The total amount of radioactive waste shipped off-site for disposal during 1999 is less than $1 \%$ of the total low-level radjoactive waste typically dispositioned annually by DOE-owned facilities. Thirty-nine cubic meters of radioactive surface contaminated scrap metals were shipped to a commercial radioactive material processing facility for radioactive metal recycling.

Off-site shipments of radioactive waste and scrap metal were controlled by written procedures to ensure compliance with State and Federal regulations and the disposal and recycling sites' criteria.

\section{Mixed Waste}

Mixed waste is waste that is both RCRA hazardous and radioactive. In 1995, the DOE voluntarily agreed to apply Pennsylvania Department of Environmental Protection (PADEP) requirements to the hazardous constituents of mixed waste. In addition, the U.S. DOE Pittsburgh Naval Reactors Office and the EPA signed a Consent Agreement/Consent Order for the storage and treatment of mixed wastes that are generated at the Site. A Site Treatment Plan for all of the Site's mixed wastes continues to be implemented in accordance with the Consent Agreement/Consent Order. Mixed wastes are not disposed of on-site. A mixed waste management program is in place to minimize generation of these wastes. In 1999, a Part B RCRA Permit for the storage of mixed waste was granted by PADEP. Three shipments of mixed waste totaling 1.8 cubic meters were made from Bettis-Pittsburgh in 1999.

\section{Environmental Assessments}

In 1988, a Preliminary Assessment and Site Inspection (PA/SI) Report was completed for the Site to meet the requirements of Section 120 of the Comprehensive. Environmental Response, Compensation, and Liability Act (CERCLA). During 1989, EPA completed their review of the Site's PASI and concluded that no further action under CERCLA was required for the Site.

In 1990, the DOE Pittsburgh Naval Reactors Office and EPA Region III signed a Consent Order to conduct a RCRA Facility Investigation (RFI) and Corrective Measures Study (CMS). The purpose of the RFI was to characterize the chemical residues in the environment at the Site and the purpose of the CMS was to determine site-specific remedial alternatives. The investigation of ground water, surface water, soil, sediment, and air specified in the RFI work plans was completed in 1993 . The Final RFI Report was approved by the EPA in August of 1994. The RFI report stated that some of the ground water under the Site and some soil areas contain low levels of chemical residues. The most prevalent residue is tetrachloroethylene which is the same solvent used to dry-clean clothing. The report included an assessment of risk to on-site and off-site populations from exposure to the chemical residues. This risk assessment concluded that there are no areas on-site or off-site which present a risk to human health that exceeds the EPA's acceptable risk criteria.

The Final CMS Report was submitted to the EPA in November 1994 and approved by the EPA in March 1995. This report recommended actions to ensure the risks to human health will remain low and to further reduce the chemical residues in the environment. 
The EPA issued its preliminary recommendations for corrective measures in September 1995 and requested public comment on the recommendations. The EPA responded to public comments and issued its final recommendations for corrective measures in October 1997. The EPA is working to issue a new Consent Order for implementation of the EPA's final corrective measures. Bettis has proactively implemented or completed many of the final recommended corrective measures.

\section{Compliance Summary}

During 1999, Site operations remained in compliance with existing permits and applicable regulations governing use, emission, transportation, and disposal of solid, liquid, and gaseous materials and wastes. During 1999, the EPA and the PADEP conducted on-site inspections of the Site's hazardous waste, and the Allegheny County Health Department conducted a boiler maintenance inspection and asbestos abatement clearance inspections. The Site was found to be in compliance with all applicable regulations. No instances of noncompliance were cited during these inspections.

Also during 1999, a Consent Order and Agreement (COA) for operation of the Springwater Intercept System was signed between the DOE Pittsburgh Naval Reactors Office and the PADEP. This COA lifted a Notice of Violation issued to Bettis by the PADEP for releases to the environment.

\section{Conclusion}

Operations at the Bettis Atomic Power Laboratory-Pittsburgh Site during 1999 did not result in any significant release of radioactivity or hazardous materials to the environment. Operations also did not have any adverse effect on human health or the quality of the environment at the Site or in the surrounding communities. 


\section{INTRODUCTION}

The first nonagrarian use of the Bettis-Pittsburgh Laboratory Site was that of an airfield which operated on the Site from approximately 1926 until 1948. This private airfield served mainly small, privately-owned planes. The general pattern of buildings and roadways currently existing on-site are based on the original airfield design.

The Bettis Laboratory was organized in 1948 through the joint efforts of Westinghouse Electric Corporation, the Navy, and the Atomic Energy Commission. Westinghouse acquired title to the Bettis airfield property ( 146 acres) and associated buildings in May of 1949 . Additional properties were purchased in 1952. In 1957, the approximately 202 acres were deeded to the Federal Government. In February 1999, Bechtel Bettis, Inc. assumed operations of the facility for the U. S. Department of Energy under the jurisdiction of the Pittsburgh Naval Reactors Office. All grounds, buildings, and equipment on the Site are the property of the Federal Government.

The primary mission of the Bettis Laboratory has always been directed toward the design, development, testing, and operational follow of nuclear reactor propulsion plants for naval surface and submarine vessels. Specifically, the Laboratory exists to support this nation's capability to deploy and maintain a modern nuclear Navy. In addition to the primary objective of continuing work in the development of the nuclear Navy, the Laboratory has also played a role in the development of the first U.S. full-scale nuclear power plant for civilian use, the Shippingport Atomic Power Plant.

This document summarizes the 1999 results of the radiological and nonradiological environmental monitoring programs at the Site. This report also discusses the Site programs for handling and offsite disposal of radioactive waste, chemical and hazardous waste, and mixed waste. The report is prepared in conformance with U. S. Department of Energy guidelines. 


\section{SITE BACKGROUND AND ENVIRONMENTAL SETTING}

The Site is situated on a 202-acre tract of land in the Borough of West Mifflin, and is located approximately eight miles southeast of the downtown section of Pittsburgh, Pennsylvania. Figure 1 shows the location of the Site with respect to the surrounding communities, and Figure 2 shows the land uses immediately adjacent to the Site. Figure 3 shows an aerial view of the developed portion of the Site. A heavily wooded area borders the Site on the east. Most of this property is owned by the Borough of West Mifflin and a portion of this property has been developed into the West Mifflin Community Park. A fence has been erected to prevent inadvertent access to the Site property from the park area. An industrial district is located along the northern boundary of the Site. Commercial and residential developments border the Site on the south and west. The land use of the region surrounding the Site is largely industrial and residential. The total population within a 50 -mile radius of the Site is approximately $3,000,000$.

\section{Physiography}

Physiography refers to the natural physical landforms of an area. The Site is located within Allegheny County, Pennsylvania, which is situated within the Allegheny Plateau physiographic province of North America. Stream erosion of a formerly raised plateau produced the present rugged land surface. The geologic formations are generally flat-lying, or gently folded and inclined. Stream frequency and the percentage of the land found in slopes decrease with distance from the major drainageways, such as the Monongahela River.

\section{Topography}

The Site is located approximately 6000 feet west of the Monongahela River. The maximum elevation at the Site is approximately 1200 feet above sea level. The minimum elevation, found at the point where the Bull Run Stream leaves the southeastern portion of the Site, is approximately 1020 feet above sea level. The normal pool elevation of the Monongahela River near the Site is approximately 720 feet above sea level. Thus, the developed portions of the Site are approximately 480 feet above the surface of the Monongahela River.

Surface drainage at the Site is primarily toward the east, discharging into the Bull Run Stream and its tributaries. The principal sources of water in the Bull Run Stream originating from the Site include once-through, noncontact cooling water, storm water runoff, and process water. The Bull Run Stream flows about 1.4 miles before joining the Thompson Run Stream which empties, about 2.6 miles downstream, into the Monongahela River in the City of Duquesne. A narrow, mostly sloped area that includes a small developed portion of the Site drains northwest toward the Thompson Run Stream. The Monongahela River is used as a raw water source for public water supply serving the Site and some surrounding communities.

Because of the location and elevation of the Site, flooding from local streams or rivers is not possible. Some minor bank overflowing of the Bull Run Stream may occur downstream from the Site during heavy rainfall.

Several springs discharge on the Site property. The largest of these, Buono Spring, RQ-20 Spring, and Northeast Spring, are on the eastem, nondeveloped portion of the Site. These are permanent springs with varying, but very low flows that are reflective of the seasons and precipitation events. In 1997, the Springwater Intercept System (SIS) was constructed to collect these springs and other seeps. The water is treated by air stripping to remove volatile organic compounds (VOCs) and the water is discharged to the Bull Run Stream basin via NPDES Outfall 007. 


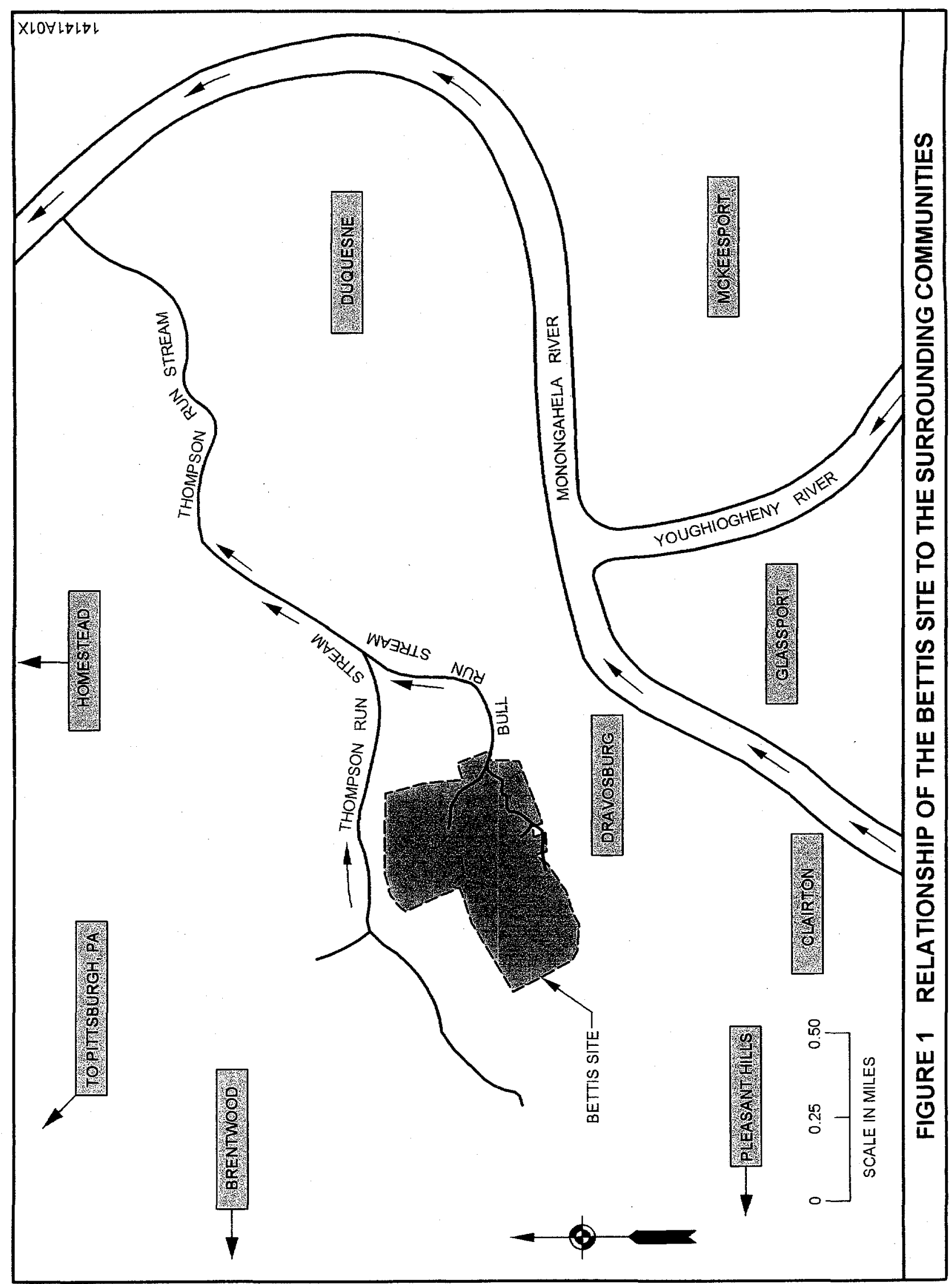




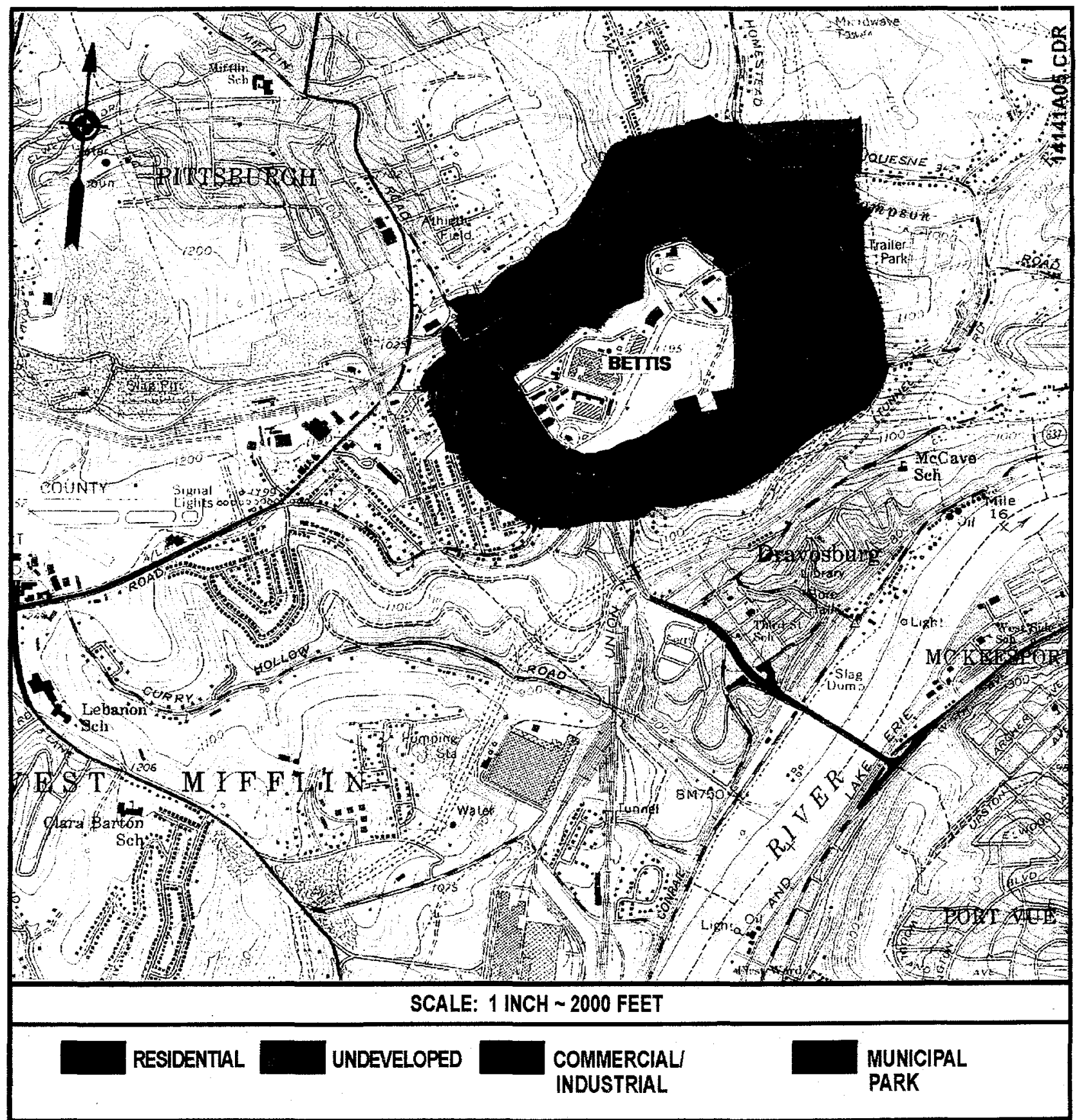

FIGURE 2 LAND USES IMMEDIATELY ADJACENT TO THE BETTIS SITE 


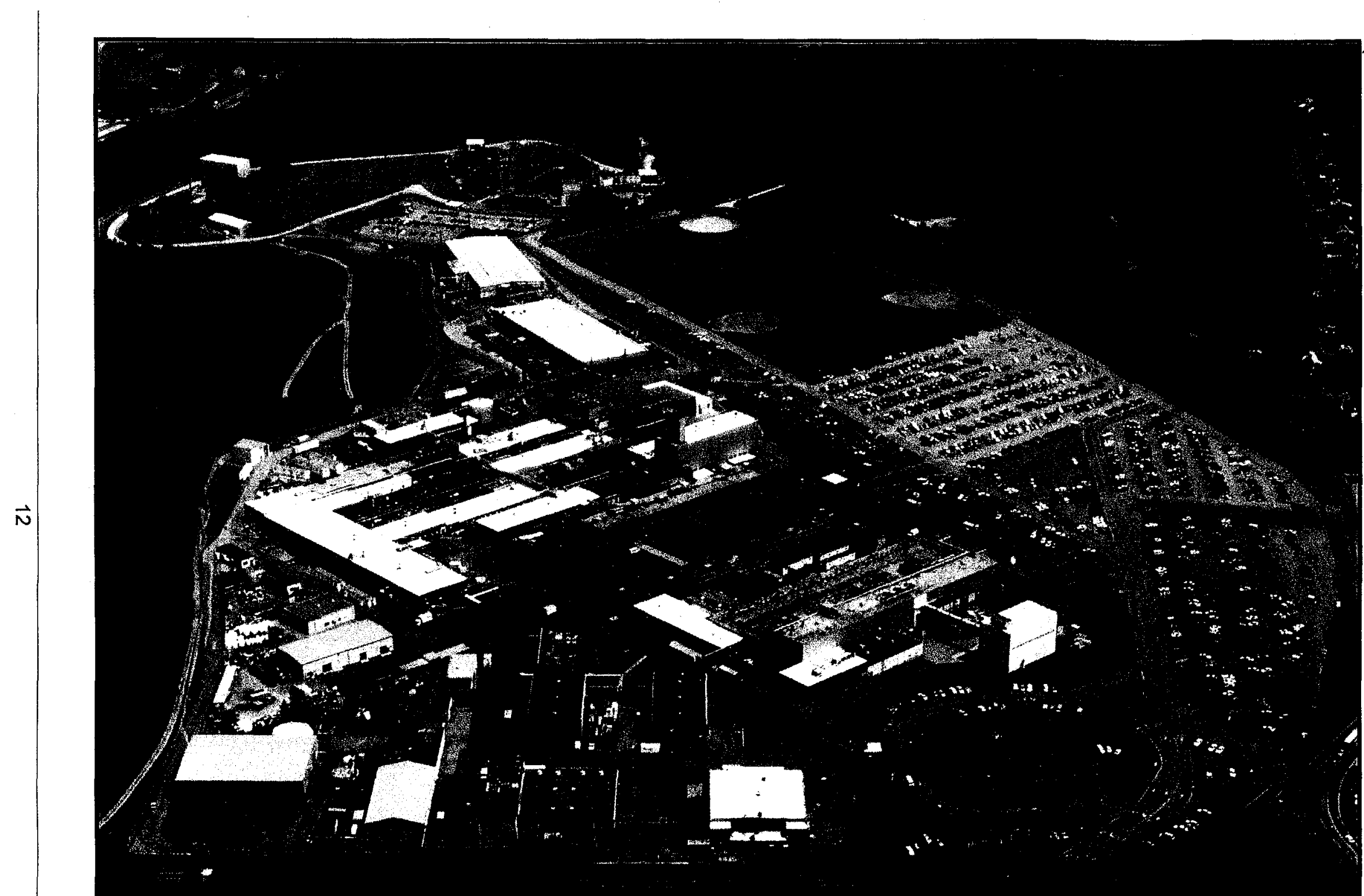

ŠEPT 1998 FIGURE 3 AERIAL VIEW OF THE DEVELOPED PORTION OF THE BETTIS LABORATORY 


\section{Soils}

The soils at the Site are residual in origin or are the result of filling operations. The residual soils were formed by weathering of the underlying Monongahela Group bedrock. The soils on-site are classified as the Culleoka and Urban Land-Guernsey soils. The Culleoka soils are characterized as moderately deep, well-drained soils formed from shale and fine-grained sandstone bedrock. They generally occur on upland slopes, have moderate permeability, and normally a water table below four feet throughout the year. The surface soil can be described as dark brown, granular silt loam, while the subsoil is yellowish-brown, blocky silt loam to channery clay loam. The substrata consists of yellowish-brown, massive, very channery clay loam.

The Urban Land-Guernsey soils are described as variable, consisting of disturbed land resulting from cut and fill operations and subsequent coverage with urban works. These soils occur in a complex pattern with Culleoka soils which are described above. The Guernsey soils are characterized as deep, well-drained soils with a low permeability and a winter water table within one or two feet of the surface. This soil type is formed from interbedded clay shale, shale, and limestone bedrock.

None of the Site land is utilized for agrarian purposes.

\section{Regional Stratigraphy}

The geologic formations that underlie the portion of Allegheny County in which the Site is located are part of the Pennsylvanian System. The Monongahela, Conemaugh, and Allegheny Groups, all part of the Pennsylvanian System, underlie the Site. The Monongahela Group, the uppermost group, includes beds of limestone, variable shales, discontinuous layers of sandstone and coal beds. The base of the Pittsburgh Coal marks the base of the Monongahela Group. Table 3 presents a generalized description of the rock strata beneath the Site.

Some of the important beds in the Monongahela Group are the Uniontown Limestone, Benwood Limestone, Sewickley Sandstone, Fishpot Limestone, Pittsburgh Sandstone; and the Redstone and Pittsburgh Coals. Core borings taken on-site confirm that the bedrock consists of layers of limestone, shale, and sandstone.

Extensive mining of the Pittsburgh Coal seam has occurred to the west and south as well as under the Site. The Pittsburgh Coal seam lies about 200-250 feet below the developed portion of the Site. Most of the Pittsburgh Coal that can be mined has been removed. There are no current coal mining activities in this area.

\section{Structural Geology}

The bedrock under the Site declines to the southeast a few feet per mile. The Pittsburgh Coal seam under the Site dips $1 \%$ to the southeast.

\section{Hydrogeology}

The Site is underlain by the geologic units of the Pennsylvanian Monongahela Group. The Monongahela Group is not an important local aquifer. Well yields from the Monongahela Group range from less than one to 30 gallons per minute. Pump tests performed at the Site in the Sewickley Sandstone Water-Bearing Zone, which is one of the main water-bearing zones in the Monongahela Group at the Site, could not sustain flow rates of one to three gallons per minute. 
TABLE 3

\begin{tabular}{|c|c|c|c|c|}
\hline \multicolumn{5}{|c|}{$\begin{array}{l}\text { GENERALIZED SECTION OF ROCK STRATA } \\
\text { BENEATH THE BETTIS LABORATORY } \\
\end{array}$} \\
\hline System & Group & Formation & Strata & Remarks \\
\hline \multirow{4}{*}{$\begin{array}{l}\mathbf{P} \\
\mathbf{E} \\
\mathbf{N} \\
\mathbf{N} \\
\mathbf{S} \\
\mathbf{Y} \\
\mathbf{L} \\
\mathbf{V} \\
\mathbf{A} \\
\mathbf{N} \\
\mathbf{I} \\
\mathbf{A} \\
\mathbf{N}\end{array}$} & Monongahela & Pittsburgh & $\begin{array}{l}\text { Cyclic sequences of } \\
\text { shale, limestone, } \\
\text { claystone, and coal. } \\
\text { Pittsburgh Coal seam } \\
\text { is bottom stratum. }\end{array}$ & $\begin{array}{l}\text { Extends from at or near } \\
\text { surface down to } \\
\text { Pittsburgh Coal. } \\
\text { Mined out about 200-250 } \\
\text { feet below Bettis. }\end{array}$ \\
\hline & Conemaugh & Casselman & $\begin{array}{l}\text { Cyclic sequences of } \\
\text { sandstone, shale, silty } \\
\text { claystone ("red beds"), } \\
\text { and thin limestone and } \\
\text { coal. }\end{array}$ & $\begin{array}{l}\text { Coal deposits of this } \\
\text { group not normally } \\
\text { mined. Formation is } \\
\text { about } 250-300 \text { feet thick; } \\
\text { base is near normal level } \\
\text { of Monongahela River. }\end{array}$ \\
\hline & & Glenshaw & $\begin{array}{l}\text { Cyclic sequences of } \\
\text { sandstone, shale, red } \\
\text { beds, and thin } \\
\text { limestone and coal; } \\
\text { fossiliferous limestone. }\end{array}$ & $\begin{array}{l}\text { Formation is } 300 \text { to } 380 \\
\text { feet thick. }\end{array}$ \\
\hline & Allegheny & Freeport & $\begin{array}{l}\text { Upper Freeport Coal } \\
\text { seam is top stratum. }\end{array}$ & $\begin{array}{l}\text { Major coal bed, } 600 \text { to } \\
630 \text { feet below level of } \\
\text { Pittsburgh Coal. }\end{array}$ \\
\hline & & $\begin{aligned} \text { aniar } \\
\text { to }\end{aligned}$ & $\begin{array}{l}\text { n Rocks extend down } \\
\text { sea level. }\end{array}$ & \\
\hline
\end{tabular}

The topographic features of the area such as high hills cut by major stream valleys, greatly affect the direction and depth of water tables. There may be subregional ground water regimes where the discharge of the ground water is to local streams. In cases where the stream channels lie below the water table, some aquifers may discharge on valley slopes.

Based on data obtained through rock coring, monitoring well drilling, geophysical logging, and ground water elevation monitoring, the ground water under the Site is present in five different water-bearing zones. The water-bearing areas are referred to as water-bearing zones rather than aquifers because the amounts of water present in these zones are not sufficient to meet the definition of an aquifer as defined by the American Geological Institute. The water-bearing zones in descending order are: Perched, Benwood Limestone, Sewickley Sandstone, Pittsburgh Sandstone, and Pittsburgh Coal. The Pittsburgh Coal Water-Bearing Zone represents the basal ground water flow at the Site. These water-bearing zones are described in detail in Reference (1).

There are no springs or wells on-site or in the local, hydraulically downgradient area which are known to be used for drinking water, industrial, or irrigation purposes. 


\section{Meteorology}

The Site has a humid, continental type of climate modified only slightly by its nearness to the Atlantic Seaboard and the Great Lakes. Data accumulated by the Site meteorological monitoring system during 1999 indicated that prevailing winds for the Site occurred about $26 \%$ of the time from the south-southeast and about $35 \%$ of the time from the west-northwest. Wind speeds of greater than five miles per hour (mph) occurred about $63 \%$ of the time and less than five mph about $37 \%$ of the time. The average monthly temperatures during the year ranged from 31 to $77^{\circ} \mathrm{F}$. The annual precipitation amounted to approximately 31.3 inches of water. 


\section{ENVIRONMENTAL MONITORING PROGRAMS}

The major elements of the Site's radiological and nonradiological environmental monitoring programs are summarized in Tables 1 and 2 . The various programs and the monitoring results are discussed in this section.

\section{A. LIQUID EFFLUENTS}

The purpose of the liquid effluent monitoring programs is to determine the effectiveness of control methods and to measure constituent concentrations in effluents for comparison with applicable standards and natural background levels. In addition to monitoring liquid effluents from the Site, samples of precipitation and influent city water are monitored and used for background comparisons.

\section{Sources}

The principal sources of liquid effluents to the storm drain system included once-through city water used for cooling purposes, surface runoff precipitation, and process water. Total effluent flow through the outfalls at the Bull Run Monitoring Station and the Northeast Monitoring Station is measured in accordance with the NPDES permit. In 1999, the total was 48,900,000 gallons for both outfalls. Approximately $88 \%$ of this volume was released at the Bull Run Monitoring Station. This comprises most of the flow in the Bull Run Stream. Storm water runoff via Storm Water Outfalls 003, 004,005 and 006 and treated ground water via Outfall 007 was also released to the environment in accordance with the Site's NPDES Permit. Figure 4 shows the locations of these outfalls.

Water used for sanitary and cleaning purposes was discharged via the sanitary sewer system to the West Mifflin Borough, Thompson Run Sewage Treatment Plant, which discharges treated effluent to the Thompson Run Stream. In addition, approximately 99,033 gallons of processed ground water and water generated from sampling efforts were discharged to the Thompson Run Sewage Treatment Plant. This water contained traces of volatile organic compounds, primarily tetrachloroethylene, which were within allowable release limits to the treatment plant. The Borough of West Mifflin, the EPA, and the PADEP had been previously notified of the discharges as required by applicable regulations.

\section{Liquid Monitoring}

The samples and analyses specified below constitute the minimum samples and analyses conducted at the Site during 1999.

Radiological: Water samples of storm drain liquid effluents were collected continuously at the Bull Run and Northeast Area Monitoring Stations shown on Figure 4. Weekly, the composite samples were picked up and analyzed for gross alpha and gross beta radioactivity. Quarterly, composites of the weekly samples were analyzed for strontium-90 and gamma-emitters. Influent city water and precipitation samples were analyzed similarly to the liquid effluent samples. Annually, a water sample is collected from the Bull Run Stream at the Site boundary (BR5, Figure 4) and analyzed for gross alpha, gross beta, radiostrontium, gamma emitters and isotopic uranium. Samples of processed ground water were analyzed for gross alpha and gross beta radioactivity prior to release of the processed water to the sanitary sewer to ensure that the processed water did not contain any detectable radioactivity. The minimum detection levels were below the levels allowed by the EPA in drinking water.

Samples of sanitary effluent were collected weekly at the outfall of the main site area, location SAN-2 shown on Figure 4. These samples were analyzed for gross alpha and gross beta radioactivity. 


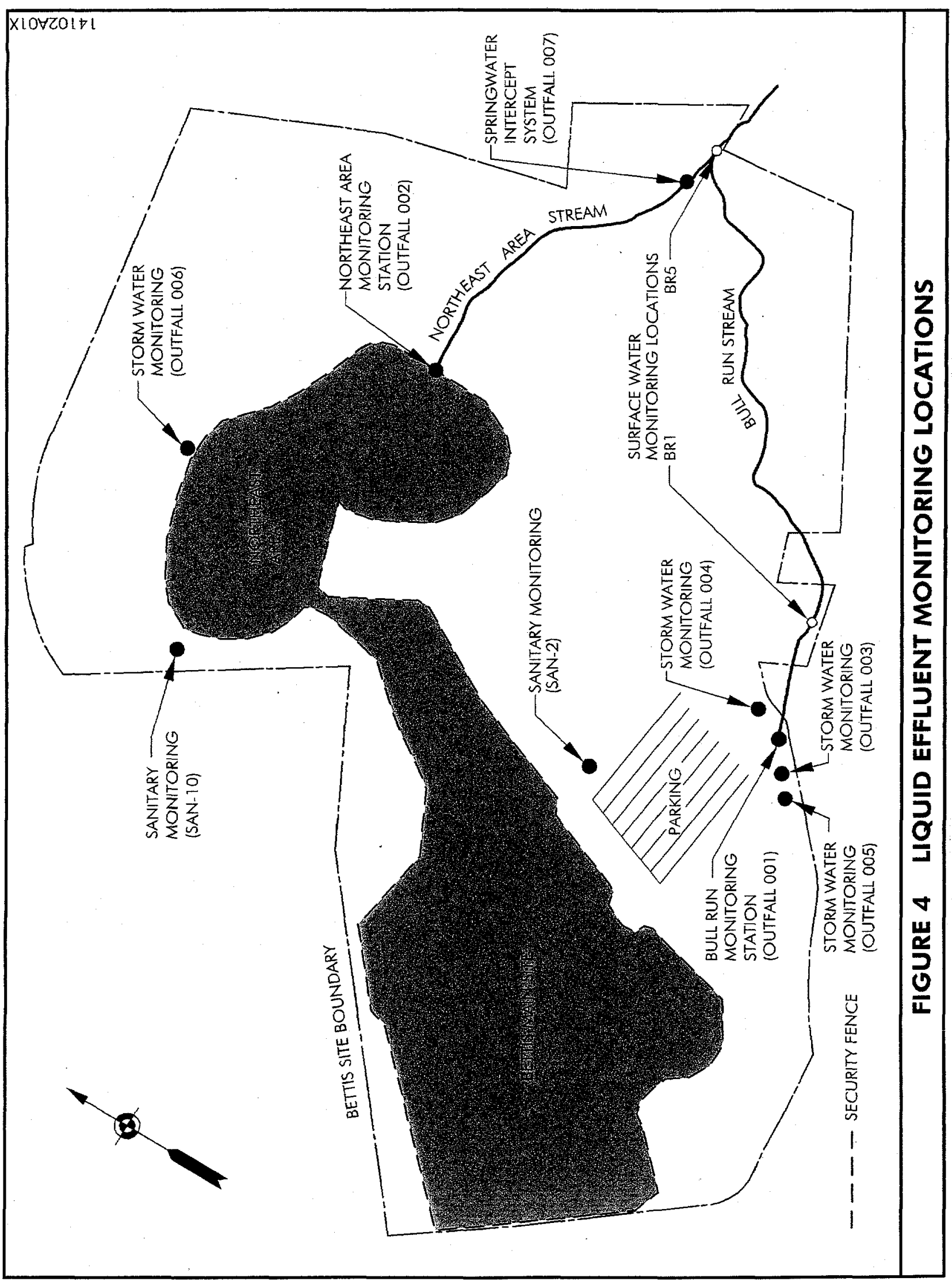


Quarterly, a composite of the weekly samples from SAN-2 was analyzed for strontium-90 and gamma emitters. Semiannually, samples of sanitary effluent were collected at the outfall of the entire Site, location SAN-10 on. Figure 4. These samples were analyzed for gross alpha and gross beta radioactivity.

Nonradiological: Semimonthly, samples of storm drain effluents discharged through the Bull Run and Northeast Area Monitoring Stations were collected and analyzed, in accordance with the NPDES permit, for oil and grease, $\mathrm{pH}$, suspended solids, and temperature and in addition, dissolved oxygen and fecal coliforms. Semiannually, samples were collected and analyzed for alkalinity, aluminum, ammonia, chloride, color, fluoride, hardness, iron (dissolved), iron (total), manganese, nitrate, nitrite, osmotic pressure, phenols, sulfate, methylene blue active substance, total dissolved solids, threshold odor, and turbidity. Annually, samples were collected and analyzed for antimony, arsenic, base neutral/acids, beryllium, cadmium, chromium (hexavalent), chromium (total), copper, cyanide (free), lead, mercury, nickel, pesticides, polychlorinated biphenyls, selenium, silver, thallium, volatile organic compounds and zinc.

Semimonthly, samples of effluent from the Springwater Intercept System (SIS) were collected at Outfall 007 and analyzed for iron (dissolved), $\mathrm{pH}$, suspended solids, tetrachloroethylene, trichloroethylene, and 1,2-dichloroethylene. These analyses are required by the Site's NPDES permit.

Samples of the influent municipal water supply, which comprised a significant portion of the Site's liquid effluents, were collected at the same frequencies and analyzed for the same parameters described above for the Bull Run and Northeast Area effluents.

Quarterly samples of storm water runoff were collected at the Bull Run Outfall (001) and Storm Water Outfalls 003, 004, 005, and 006 and analyzed for fecal coliforms. Samples of storm water runoff from Storm Water Outfalls 004 and 005 were also analyzed for aluminum. These analyses are required by the Site's NPDES Permit.

Semiannually, samples of sanitary effluent were collected at the outfall of the entire Site, location SAN-10. These samples were analyzed for biochemical oxygen demand, dissolved oxygen, oil and grease, $\mathrm{pH}$, and temperature. Annually, samples of sanitary effluent were collected and analyzed for chromium (hexavalent), chromium (total), cyanide (free), lead, mercury, and silver.

Samples of Bull Run Stream were collected from two locations, BR1 and BR5 shown on Figure 4, and analyzed for volatile organic compounds.

\section{Liquid Analyses}

Radiological: Liquid samples (liquid effluent, city water, precipitation, sanitary effluent, ground water, etc.) were prepared for gross alpha and beta analysis by evaporation of approximately $200 \mathrm{ml}$ of liquid. The alpha and beta radioactivity of the samples were measured using a low background proportional counter. Typical minimum detection levels for alpha and beta radioactivity for $200 \mathrm{ml}$ samples were $2.0 \times 10^{-9} \mu \mathrm{Ci} / \mathrm{ml}$ and $3.0 \times 10^{-9} \mu \mathrm{Ci} / \mathrm{ml}$, respectively.

Gamma spectrometry was also performed quarterly on composites of weekly samples to identify gamma-emitting radionuclides using a Germanium-Lithium or a Germanium detector and a multichannel analyzer. A typical minimum detection level for cesium-137 and cobalt-60 in a $500 \mathrm{ml}$ sample of these composites was $5.0 \times 10^{-9} \mu \mathrm{Ci} / \mathrm{ml}$.

Strontium-90 analyses were performed on selected composites of weekly samples using a standard strontium radiochemical procedure. A typical minimum detection level achieved for strontium- 90 was $5.0 \times 10^{-10} \mu \mathrm{Ci} / \mathrm{ml}$ for a $1000 \mathrm{ml}$ sample. 
Nonradiological: Analyses of influent, effluent, and surface water samples were performed using test methods described in References (2), (3), or other EPA-approved methods.

\section{Liquid Monitoring Results and Conclusions}

Radiological: The results of the weekly analyses for alpha radioactivity in the Site's storm drain effluents showed that the levels were very near or below the minimum detection level and were typical of the background alpha radioactivity levels measured in the city water influent and precipitation. None of 52 alpha radioactivity measurements of the effluents exceeded the limit of Reference (4) for alpha radioactivity, based on thorium-232, in water in uncontrolled areas.

The results of the weekly analyses for beta radioactivity in the Site's storm drain effluents showed that the beta radioactivity levels were typical of the levels measured in the city water influent and precipitation. None of the 52 beta radioactivity measurements of the effluents exceeded the limit of Reference (4) for beta radioactivity, based on strontium-90, in water in uncontrolled areas.

Table 4 presents the quarterly composite sample results for the Site's storm drain effluents at the Bull Run and Northeast Area Monitoring Stations and for precipitation and city water samples. The quarterly composite radioactivity results for the potential contaminants-of-concern for the Site's effluents, city water, and precipitation were all less than the minimum detection levels.

There was one occasion during 1999 when the gross radioactivity levels in the sanitary effluent slightly exceeded local control levels. On this occasion, the gross beta was $7.7 \times 10^{-8} \mu \mathrm{Ci} / \mathrm{ml}$ and an investigation revealed that the elevated activity was due to the presence of thallium-201 and technetium-99m. Thallium-201 and technetium-99m are medical isotopes and are not associated with Bettis operations.

The alpha and beta radioactivity levels in processed ground water released to the sanitary sewer were less than the minimum detection level of $3.0 \times 10^{-9} \mu \mathrm{Ci} / \mathrm{ml}$. This level is below the level allowed by the EPA in drinking water and is typical of natural background levels.

The alpha, beta, and radiostrontium radioactivity levels in the sample of Bull Run Stream at location BR5 (Figure 4) were at or below minimum detection levels. The natural uranium concentrations were: uranium 234, $0.66 \times 10^{-9} \mu \mathrm{Ci} / \mathrm{ml}$, uranium-235, $<0.18 \times 10^{-9} \mu \mathrm{Ci} / \mathrm{ml}$, and uranium-238, $0.52 \times 10^{-9}$ $\mu \mathrm{Ci} / \mathrm{ml}$. These uranium concentrations are consistent with natural background concentrations for uranium in surface water.

Based on the above, the control methods at the Site were effective in ensuring that the water discharged from the Site was of sufficiently high quality to preclude an adverse impact on the environment or downstream water quality. Site-generated radioactivity was not released to the Site's effluent streams or sanitary sewers. 
TABLE 4

\begin{tabular}{|c|c|c|c|c|c|}
\hline LIQUID INFLUENT & $\begin{array}{l}\text { D EFFLUE } \\
\text { Units } 10^{-}\end{array}$ & $\begin{array}{l}\text { T RADI } \\
\mu \mathrm{Ci} / \mathrm{ml}\end{array}$ & ACTIVI & Y RES & $\mathbf{L T S}^{(1)}$ \\
\hline $\begin{array}{l}\text { Sample } \\
\text { Location }\end{array}$ & $\begin{array}{l}\text { Activity } \\
\text { Analysis }\end{array}$ & $\begin{array}{l}\text { First } \\
\text { Quarter }\end{array}$ & $\begin{array}{l}\text { Second } \\
\text { Quarter }\end{array}$ & $\begin{array}{l}\text { Third } \\
\text { Quarter }\end{array}$ & $\begin{array}{l}\text { Fourth } \\
\text { Quarter }\end{array}$ \\
\hline $\begin{array}{l}\text { Bull Run Monitoring Station } \\
\text { Effluent }\end{array}$ & \multirow{4}{*}{ Strontium-90 } & $<0.43$ & $<0.20$ & $<0.30$ & $<0.33$ \\
\hline $\begin{array}{l}\text { Northeast Area Monitoring } \\
\text { Station Effluent }\end{array}$ & & $<0.50$ & $<0.37$ & $<0.28$ & $<0.37$ \\
\hline Precipitation & & $<0.48$ & $<0.22$ & $<0.29$ & $<0.27$ \\
\hline City Water & & $<0.51$ & $<0.35$ & $<0.27$ & $<0.38$ \\
\hline $\begin{array}{l}\text { Bull Run Monitoring Station } \\
\text { Effluent }\end{array}$ & \multirow{4}{*}{ Cesium-137 } & $<6.2$ & $<7.0$ & $<6.7$ & $<5.5$ \\
\hline $\begin{array}{l}\text { Northeast Area Monitoring } \\
\text { Station Effluent }\end{array}$ & & $<6.7$ & $<5.7$ & $<5.7$ & $<6.3$ \\
\hline Precipitation & & $<7.1$ & $<6.8$ & $<5.6$ & $<6.4$ \\
\hline City Water & & $<5.6$ & $<6.0$ & $<6.5$ & $<5.4$ \\
\hline $\begin{array}{l}\text { Bull Run Monitoring Station } \\
\text { Effluent }\end{array}$ & \multirow{4}{*}{ Cobalt-60 } & $<5.6$ & $<6.0$ & $<5.6$ & $<4.9$ \\
\hline $\begin{array}{l}\text { Northeast Area Monitoring } \\
\text { Station Effluent }\end{array}$ & & $<5.6$ & $<5.3$ & $<5.5$ & $<5.5$ \\
\hline Precipitation & & $<5.8$ & $<5.3$ & $<5.0$ & $<5.6$ \\
\hline City Water & & $<5.3$ & $<5.6$ & $<5.8$ & $<5.6$ \\
\hline
\end{tabular}

NOTE: (1) < signifies the data were below the minimum detection level (MDL). The MDL varies slightly due to the sample size, the chemical recovery yield, count time, and the presence of dissolved materials.

Nonradiological: A summary of sample analysis results for influent city water and effluent water from the Site are presented in Tables 5, 6, and 7. Since a major portion of the Site's process waste water effluent is noncontact cooling water, the quality of the effluent is significantly influenced by the quality of the influent city water. Therefore, the influent city water was sampled for the same parameters as the effluent. Table 5 provides the analysis results for the parameters that are required to be sampled by the Site's National Pollutant Discharge Elimination System (NPDES) Permit. Table 5 also identifies the discharge limits for these parameters as established in the NPDES Permit. Tables 6 and 7 provide the analysis results for various parameters that provide an overall indication of general water quality. Tables 6 and 7 also list the guidelines for general water quality that have been derived from guidelines provided by the Pennsylvania Department of Environmental Protection in Reference (5). These guidelines are not effluent limits, but can be compared against the analysis results to provide an indication of the quality of the effluent from the Site. 
The results in Table 5 show that the samples collected in accordance with the Site's NPDES Permit were within the established discharge limits. The sample results for the storm water outfalls in Table 5 indicate the presence of fecal coliform bacteria. An investigation of the possible sources of the fecal coliforms indicated that the on-site sanitary sewer lines are not the cause for the presence of the fecal coliforms. Sampling has indicated that the levels of fecal coliforms in Outfall 001 are influenced by off-site storm water containing fecal coliforms. A review of EPA documents which discuss storm water quality indicated that the levels of fecal coliforms detected in the storm water outfalls are consistent with those found in typical urban storm water runoff.

In addition, the general water quality results in Tables 6 and 7 show that nearly all of the nonregulated parameter analysis results were within the water quality guidelines with a few variances as explained below. The copper level in the Outfall 001 effluent $(0.032 \mathrm{mg} / \mathrm{l})$ exceeded the maximum concentration guideline $(0.026 \mathrm{mg} / \mathrm{l})$. The elevated copper level in the Outfall 001 effluent was primarily attributed to the elevated baseline copper concentration $(0.028 \mathrm{mg} / \mathrm{l})$ in the city water influent.

The fecal coliform levels in Outfall 002 exceeded the guideline. An investigation determined that a malfunctioning sanitary sewage ejector pit caused the elevated fecal coliform levels. Sanitary sewage backed up into a sanitary manhole and subsequently leaked into the soil. A small amount of sanitary sewage was then washed into an adjacent storm drain during precipitation events. This storm drain discharges to Outfall 002 . The sewage ejector pit equipment has been repaired.

The dissolved oxygen levels at Outfall $001(1.0 \mathrm{mg} / \mathrm{l})$ and Outfall $002(1.0 \mathrm{mg} / \mathrm{l})$ were below the minimum recommended guideline $(4.0 \mathrm{mg} / \mathrm{l})$. The low dissolved oxygen level at the outfalls was primarily attributed to the low dissolved oxygen concentration $(1.0 \mathrm{mg} / \mathrm{l})$ in the city water influent. In addition, the low dissolved oxygen level in the sanitary effluent $(<1.0 \mathrm{mg} / \mathrm{l})$ was also attributed to the low dissolved oxygen concentration in the city water influent.

The phenol level in the Outfall 001 effluent $(0.0066 \mathrm{mg} / \mathrm{l})$ exceeded the maximum concentration guideline $(0.005 \mathrm{mg} / \mathrm{l})$. The elevated phenol level in the Outfall 001 effluent was primarily attributed to the elevated phenol concentration $(0.0056 \mathrm{mg} / \mathrm{l})$ in the city water influent.

The zinc level in the Outfall 001 effluent $(0.200 \mathrm{mg} / \mathrm{l})$ exceeded the maximum concentration guideline $(0.105 \mathrm{mg} / \mathrm{l})$. The elevated zinc level in the Outfall 001 effluent was primarily attributed to the elevated zinc concentration $(0.230 \mathrm{mg} / \mathrm{l})$ in the city water influent.

Volatile organic compound samples were collected from the Bull Run Stream at locations BR1 and BR5 (Figure 4). Results for volatile organic compounds of concern were less than the analytical laboratory's minimum detection levels, typically $0.005 \mathrm{mg} /$.

Based on the above, the control methods at the Site were effective in ensuring that the water discharged from the Site was of sufficiently high quality to preclude any adverse impact on the environment or downstream water quality. 
TABLE 5

\begin{tabular}{|c|c|c|c|c|c|c|c|c|}
\hline & IMINA & $\begin{array}{l}\text { SUMMA } \\
\text { ION SYS }\end{array}$ & $\begin{array}{l}\text { Y OF N } \\
\text { EM N NP }\end{array}$ & $\begin{array}{l}\text { TIONA } \\
\text { OES) PE }\end{array}$ & $\begin{array}{l}\text { OLLUT } \\
\text { IT SA }\end{array}$ & E ANA & $\begin{array}{l}\text { SIGE } \\
\text { SISESU }\end{array}$ & (1) \\
\hline & & Outfall 001 & Outfall 002 & Outfall 003 & Outfall 004 & Outfall 005 & Outfall 006 & Outfall 007 \\
\hline Parameter ${ }^{(2)}$ & Units & Range & Range & Range & Range & Range & Range & Range \\
\hline Aluminum & $\mathrm{mg} / \mathrm{l}$ & & & & $0.38-4.8$ & $0.42-1.6$ & & \\
\hline $\begin{array}{l}\text { Dissolved } \\
\text { Iron }\end{array}$ & $\mathrm{mg} / \mathrm{l}$ & $\sqrt{1.9}$ & & & & & & $<0.01-<0.050$ \\
\hline $\begin{array}{l}\text { Fecal } \\
\text { Coliforms }^{(3)}\end{array}$ & $\begin{array}{c}\text { colonies/ } \\
100 \mathrm{ml}\end{array}$ & $800-2950$ & & $<100-3150$ & $<100-550$ & $<100-100$ & $<100-343000$ & \\
\hline $\begin{array}{l}\text { Oil and } \\
\text { Grease }\end{array}$ & $\mathrm{mg} /$ & $<1.0-4.6$ & $<1.0-2.5$ & & & & & \\
\hline $\mathrm{pH}$ & units & $7.6-8.4$ & $7.6-8.5$ & & & & & $8.0-8.4$ \\
\hline $\begin{array}{l}\text { Suspended } \\
\text { Solids }\end{array}$ & $\mathrm{mg} / \mathrm{l}$ & $<1.0-8.0$ & $<1.0-4.8$ & & 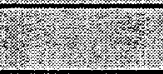 & & & $<1.0-3.0$ \\
\hline Temperature & $\mathbf{F}$ & $39-81$ & $37-70$ & & & & & \\
\hline $\begin{array}{l}\text { Tetrachloro- } \\
\text { ethylene }\end{array}$ & $\mathrm{mg} / \mathrm{l}$ & 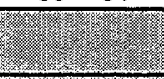 & & & 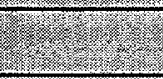 & & 47 & $<0.001$ \\
\hline $\begin{array}{l}\text { Trichloro- } \\
\text { ethylene }\end{array}$ & $\mathrm{mg} / \mathrm{l}$ & & & & & & r & $<0.001$ \\
\hline $\begin{array}{l}\text { 1,2-Dichloro- } \\
\text { ethylene }\end{array}$ & $\mathrm{mg} / \mathrm{l}$ & & & & & & 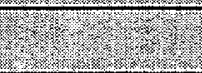 & $<0.001$ \\
\hline
\end{tabular}

NOTES:

(1) The parameters listed are required to be sampled in accordance with the National Pollutant Discharge Elimination System (NPDES) Permit for the Site. Fecal coliform storm water runoff samples are required to be collected quarterly from Outfalis $001,003,004,005$, and 006. Aluminum storm water runoff samples are required to be collected quarterly from Outfalls 004 and 005 . Oil and grease, $\mathrm{pH}$, suspended solids, and temperature samples are required to be collected semimonthly from Outfalls 001 and 002 . Dissolved iron, pH, suspended solids, tetrachloroethylene, trichloroethylene, and 1,2-dichloroethylene are required to be collected semimonthly from Outfall 007.

(2) NPDES Permit concentration limits for Outfall 001 and 002 are: oil and grease $=30 \mathrm{mg} / \mathrm{maximum}$ and $15 \mathrm{mg} / \mathrm{l}$ average; $\mathrm{pH}$ between 6.0 and 9.0 units; suspended solids $=50 \mathrm{mg} / 1$ maximum and $25 \mathrm{mg} / \mathrm{l}$ average; and temperature $=110$ degrees F maximum. NPDES Permit concentration limits for Outfall 007 are: dissolved iron $=7.0 \mathrm{mg} / \mathrm{l}$ maximum; suspended solids $=75 \mathrm{mg} / \mathrm{l}$ maximum and $30 \mathrm{mg} / \mathrm{l}$ average; trichloroethylene $=0.0055$ maximum and 0.0022 average; and trichloroethylene and 1,2 -dichloroethylene $=0.0125 \mathrm{mg} /$ maximum and $0.005 \mathrm{mg} / \mathrm{l}$ average for each compound. Concentration limits for aluminum and fecal coliform are not specified in the NPDES Permit.

(3) The fecal coliform levels shown above are generally typical of urban runoff as reported in the Handbook for Uiban Runoff Prevention and Control Planning (EPA625/R-93/004 dated September, 1993). The EPA notes that the primary source of bacteria in urban runoff is from animal wastes which is consistent with the source of fecal coliforms detected in the Bettis storm water runoff. 


\section{TABLE 6}

\begin{tabular}{|c|c|c|c|c|c|c|}
\hline & & $\begin{array}{l}\text { SUMMARI } \\
\text { LUENT A }\end{array}$ & $\begin{array}{l}\text { OF SEMIMO } \\
\text { D EFFLUEN' }\end{array}$ & $\begin{array}{l}\text { THLY AND SE } \\
\text { NATER QUAL }\end{array}$ & $\begin{array}{l}\text { IIANNUAL } \\
\text { TY RESULTS }\end{array}$ & \\
\hline & & & Influent City Water & Outfall 001 & Outfall 002 & Sanitary Effluent \\
\hline Parameter & Units & Guideline $^{(1)}$ & Range & Range & Range & Range \\
\hline Alkalinity & $\begin{array}{l}\mathrm{mg} / \mathrm{las} \\
\mathrm{CaCO}_{3} \\
\end{array}$ & $>20$ & $43.8-44.0$ & $49.1-53.0$ & $70.0-85.6$ & \\
\hline Aluminum & $\mathrm{mg} / \mathrm{l}$ & 20 & $<0.050-0.049$ & $<0.050-0.070^{(2)}$ & $<0.050-0.057$ & \\
\hline Ammonia & $\mathrm{mg} / \mathrm{l}$ & 0.7 & $<0.050$ & $<0.050-0.075$ & $<0.050-0.39$ & \\
\hline $\begin{array}{l}\text { Biochemical } \\
\text { Oxygen Demand }\end{array}$ & $\mathrm{mg} / \mathrm{l}$ & & $x+2 x^{2}$ & 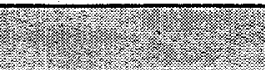 & (n) & $94-170$ \\
\hline Chloride & $\mathrm{mg} / \mathrm{l}$ & & $38.0-57.7$ & $45.0-56.2$ & $79.6-100.0$ & \\
\hline Color & units & 30 & $<5$ & $<5$ & $<5$ & \\
\hline Fecal Coliform & $\begin{array}{l}\text { colonies/ } \\
100 \mathrm{ml}\end{array}$ & $200^{(3)}$ & $<10-20$ & $<10-149^{(2)}$ & $75-1900$ & \\
\hline Fecal Coliform & $\begin{array}{c}\text { colonies/ } \\
100 \mathrm{ml}\end{array}$ & $2000^{(4)}$ & $<10$ & $10-166^{(2)}$ & $12-1900$ & \\
\hline Fluoride & $\mathrm{mg} / \mathrm{l}$ & 2.0 & $0.62-0.87$ & $0.88-0.99$ & $0.71-0.76$ & \\
\hline Hardness & $\mathrm{mg} / \mathrm{l}$ & 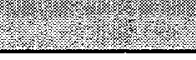 & $171-200$ & $166-220$ & $184-250$ & \\
\hline Iron, Dissolved & $\mathrm{mg} / \mathrm{l}$ & 0.3 & $<0.050$ & $<0.050$ & $<0.050$ & \\
\hline Iron, Total & $\mathrm{mg} / \mathrm{I}$ & 1.5 & $<0.050$ & $<0.050-0.083$ & $<0.050-0.058$ & \\
\hline Manganese & $\mathrm{mg} / \mathrm{n}$ & 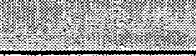 & $<0.010$ & $<0.010-0.022$ & $<0.010-0.040$ & \\
\hline $\begin{array}{l}\text { Methylene Blue } \\
\text { Active Substance }\end{array}$ & $\mathrm{mg} / \mathrm{I}$ & 20. & $<0.025-0.030$ & $0.039-0.048$ & $0.032-0.036$ & \\
\hline $\begin{array}{l}\text { Nitrite and } \\
\text { Nitrate }\end{array}$ & $\mathrm{mg} / \mathrm{l}$ & 10 & $0.934-1.304$ & $0.845-1.322$ & $0.794-1.520$ & 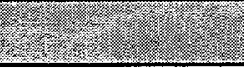 \\
\hline Oil and Grease & $\mathrm{mgh}$ & 100 & $<1.0-1.7$ & (x) & 2 & $38-84$ \\
\hline $\begin{array}{l}\text { Osmotic } \\
\text { Pressure }\end{array}$ & $\begin{array}{c}\text { Mosml } \\
\mathrm{Kg}\end{array}$ & 50 & $6.5-9.1$ & $7.0-10.8$ & $10.2-11.3$ & \\
\hline $\begin{array}{l}\text { Oxygen, } \\
\text { Dissolved }\end{array}$ & $\mathrm{mg} / \mathrm{l}$ & $>4.0$ & $1.0-12.4$ & $1.0-9.9$ & $1.0-11.7$ & $<1.0-4.1$ \\
\hline $\mathrm{pH}$ & units & $5.5-9.0$ & $6.3-7.6$ & 4 & s. & 8.4 \\
\hline Phenol & $\mathrm{mg} / \mathrm{n}$ & 0.005 & $<0.0040-0.0056$ & $<0.0040-0.0066$ & $<0.0040-0.0041$ & \\
\hline $\begin{array}{l}\text { Solids, } \\
\text { Dissolved }\end{array}$ & $\mathrm{mg} / \mathrm{l}$ & 1500 & $290-438$ & $320-516$ & $440-555$ & 20 \\
\hline Sulfate & $\mathrm{mg} / \mathrm{I}$ & 85: & $130-200$ & $120-240$ & $130-230$ & \\
\hline Temperature & $\mathbf{F}$ & 80 & $36-84$ & 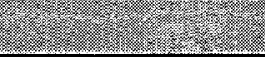 & 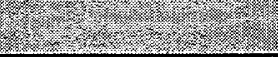 & $75-77$ \\
\hline $\begin{array}{l}\text { Threshold } \\
\text { Odor Number }\end{array}$ & $\#$ & & $<1$ & $<1$ & $<1$ & \\
\hline Turbidity & units & (2) & $<0.050$ & 0.60 & $0.50-0.60$ & \\
\hline
\end{tabular}

NOTES:

(1) Guidelines for general water quality parameters are based on the guidelines for warm water fishes as identified by the PADEP in Pennsylvania Code, Title 25, Chapter 93, Water Quality Standards. The guidelines noted are for Outfalls 001 and 002 and do not apply to sanitary effluent. Applicable sanitary effluent guidelines are based on West Mifflin Borough Ordinance 717.

(2) These aluminum and fecal coliform results do not include the resuits provided in Table 5 which are collected as part of the storm water sampling program. The results shown are from samples that were collected mainly during periods of little or no precipitation.

(3) The guideline is the geometric mean of five consecutive samples collected on different days for the period May 1 to September 30 . The analysis results are the minimum and maximum geometric means of five consecutive samples collected on different days during this period.

(4) The guideline is the geometric mean of five consecutive samples collected on different days for the period October 1 to April 30 . The analysis results are the minimum and maximum geometric means of five consecutive samples collected on different days during this period. 
TABLE 7

\begin{tabular}{|c|c|c|c|c|c|c|}
\hline \multicolumn{7}{|c|}{ ANNUAL INFLUENT AND EFFLUENT WATER QUALITY RESULTS } \\
\hline Parameter & Units & Guideline $^{(1)}$ & $\begin{array}{l}\text { Influent City } \\
\text { Water }\end{array}$ & Outfall 001 & Outfall 002 & Sanitary Effluent \\
\hline Antimony & $\mathrm{mg} / 1$ & 1.095 & $<0.030$ & $<0.030$ & $<0.030$ & \\
\hline Arsenic & $\mathrm{mg} / \mathrm{l}$ & 0.360 & $<0.0050$ & $<0.0050$ & $<0.0050$ & \\
\hline $\begin{array}{l}\text { Base Neutrals/ } \\
\text { Acids } \\
\text { Bis(2- } \\
\text { ethylhexyl)ipthalate } \\
\text { Diethyl phthalate } \\
\end{array}$ & $\mathrm{mg} / \mathrm{l}$ & $\begin{array}{l}-(2) \\
4.545 \\
4.000\end{array}$ & $\begin{array}{l}-\overline{-}^{(2)} \\
<0.010 \\
<0.010\end{array}$ & $\begin{array}{c}\overline{-}^{(2)} \\
0.0015 J^{(3)} \\
0.0024 J^{(3)}\end{array}$ & $\begin{array}{l}-{ }^{(2)} \\
<0.010 \\
<0.010\end{array}$ & \\
\hline Beryllium & $\mathrm{mg} / 1$ & 2 & $<0.00020$ & $<0.00020$ & $<0.00020$ & \\
\hline Cadmium & $\mathrm{mg} / \mathrm{l}$ & 0.0062 & $<0.0050$ & $<0.0050$ & $<0.0050$ & \\
\hline $\begin{array}{l}\text { Chromium, } \\
\text { Hexavalent }\end{array}$ & $\mathrm{mg} / \mathrm{l}$ & 0.015 & $<0.010$ & $<0.010$ & $<0.010$ & 0.025 \\
\hline Chromium, Total & $\mathrm{mg} / 1$ & 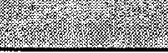 & $<0.010$ & $<0.010$ & $<0.010$ & $<0.010$ \\
\hline Copper & $\mathrm{mg} / \mathrm{l}$ & 0.026 & 0.028 & 0.032 & $<0.010$ & 5 \\
\hline Cyanide, Free & $\mathrm{mg} / \mathrm{I}$ & 0.022 & $<0.0050$ & $<0.0050$ & $<0.0050$ & $<0.0050$ \\
\hline Lead & $\mathrm{mg} / \mathrm{l}$ & 0.137 & 0.0032 & 0.0036 & $<0.0030$ & 0.018 \\
\hline Mercury & $\mathrm{mg} / \mathrm{n}$ & 0.0025 & $<0.00020$ & $<0.00020$ & $<0.00020$ & 0.00029 \\
\hline Nickel & $\mathrm{mg} / \mathrm{h}$ & 2 & $<0.020$ & $<0.020$ & $<0.020$ & \\
\hline Pesticides & $\mathrm{mg} / \mathrm{l}$ & $-^{(2)}$ & $-(2)$ & $-(2)$ & $-(2)$ & \\
\hline $\begin{array}{l}\text { Polychlorinated } \\
\text { Biphenyls }\end{array}$ & $\mathrm{mg} / \mathrm{l}$ & 0.001 & $<0.001$ & $<0.001$ & $<0.001$ & \\
\hline Selenium & $\mathrm{mg} / \mathrm{l}$ & 0.020 & $<0.0050$ & $<0.0050$ & $<0.0050$ & \\
\hline Silver & $\mathrm{mg} / \mathrm{I}$ & 0.0082 & $<0.00020$ & $<0.00020$ & $<0.00020$ & 0.00052 \\
\hline Thallium & $\mathrm{mg} n$ & 0.065 & $<0.010$ & $<0.010$ & $<0.010$ & \\
\hline $\begin{array}{l}\text { Volatile Organic } \\
\text { Compounds } \\
\text { Bromodichloromethane } \\
\text { Chloroform } \\
\text { Dibromochloromethane }\end{array}$ & $\mathrm{mg} / \mathrm{l}$ & $\begin{array}{l}-(2) \\
\overline{-}^{(4)} \\
1.945 \\
-(4)\end{array}$ & $\begin{array}{l}-{ }^{(2)} \\
0.020 \\
0.0355 \\
0.0111\end{array}$ & $\begin{array}{l}-\overline{-}^{(2)} \\
0.0018 \mathrm{~J}^{(3)} \\
0.0021 \mathrm{~J}^{(3)} \\
0.002 \mathrm{~J}^{(3)}\end{array}$ & $\begin{array}{l}-(2) \\
<0.005 \\
<0.005 \\
<0.005\end{array}$ & \\
\hline Zinc & $\mathrm{mg} / \mathrm{l}$ & 0.165 & 0.230 & 0.200 & 0.110 & \\
\hline
\end{tabular}

NOTES:

(1) The guideline is the maximum concentration guideline based on the fish and aquatic life criteria provided by the Pennsylvania Department of Environmental Protection in Pennsylvania Code, Title 25, Chapter 16, Water Quality Toxics Management Strategy. The guidelines noted are for Outfalls 001 and 002 and do not apply to sanitary effiluent. A hardness value of $150 \mathrm{mg} /$ was used to calculate several guidelines.

(2) A complete listing of the compounds analyzed along with the associated guidelines are identified in Appendix A, Table 1, Chapter 16, Water Quality Toxics Management Strategy. Analysis results for each compound analyzed were less than the minimum detection level for the parameter unless otherwise specified.

(3) " $\mathrm{J}$ " data qualifier indicates that analyte is present, but reported value may not be accurate or precise.

(4) No specific guideline available. 


\section{B. GROUND WATER}

The purpose of the ground water monitoring programs is to determine the impact of operations on the ground water. The nonradiological monitoring program is also performed to monitor for the migration of chemical residues in ground water.

\section{Sources}

The primary source of radioactivity and chemical constituents in the Site's ground water is from operations conducted in the 1950's and 1960's. During that time, small amounts of radioactivity were released from a few isolated locations on-site as a result of minor breaches in containers and underground pipes containing radioactive materials. Since that time, vigorous efforts to prevent recurrence of these problems have been successful, and much of the soil containing residual radioactivity has been removed. However, there remain some areas of soil within the Site confines that contain small amounts of radioactivity from past Site operations. Monitoring is conducted to detect any influence of this activity on water quality.

The chemical constituents originated from infrequent spills or the past practice of on-site disposal of small amounts of spent solvents, typically degreasing agents such as tetrachloroethylene from Site operations. It is also possible that solvent disposal by prior tenants when the Site was an airfield may have contributed to the ground water contamination. Since the early 1970 s, these materials have been disposed of off-site.

\section{Ground Water Monitoring}

The samples and analyses specified below constitute the minimum samples and analyses conducted at the Site during 1999. The well locations and on-site springs are shown on Figure 5 . The wells monitor five water-bearing zones under the Site down to and including the Pittsburgh Coal WaterBearing Zone. These water-bearing zones, which are illustrated and discussed in detail in the Final RFI Report, Reference (1), are listed below in order of increasing depth: Perched, Benwood Limestone, Sewickley Sandstone, Pittsburgh Sandstone, and Pittsburgh Coal. The on-site springs and seeps are surface discharge points for water predominantly from the Benwood or Sewickley. Water-Bearing Zones.

Radiological: Ground water samples, from on-site and off-site springs, select wells and a discharge point for the abandoned Pittsburgh Coal Mine under the site, were collected at least annually and analyzed typically for gross alpha, gross beta, strontium-90, gamma-emitters, and uranium isotopes.

Seepage samples were collected from the Inactive Waste Site, and Valley National Gases and Duquesne Light properties and analyzed for gross alpha, gross beta, strontium-90, gamma-emitters, and uranium isotopes.

Nonradiological: Ground water samples were collected from select wells and a discharge point for the abandoned Pittsburgh Coal Mine under the Site at least annually and analyzed for volatile organic compounds. In addition, three wells from each water-bearing zone are sampled every third year for additional inorganic and organic analyses to provide additional water quality data.

Seepage samples were collected from Duquesne Light and Valley National Gases properties and analyzed for volatile organic compounds. There was insufficient seepage to permit collection of samples for polynuclear aromatic hydrocarbons and polychlorinated biphenyls. 


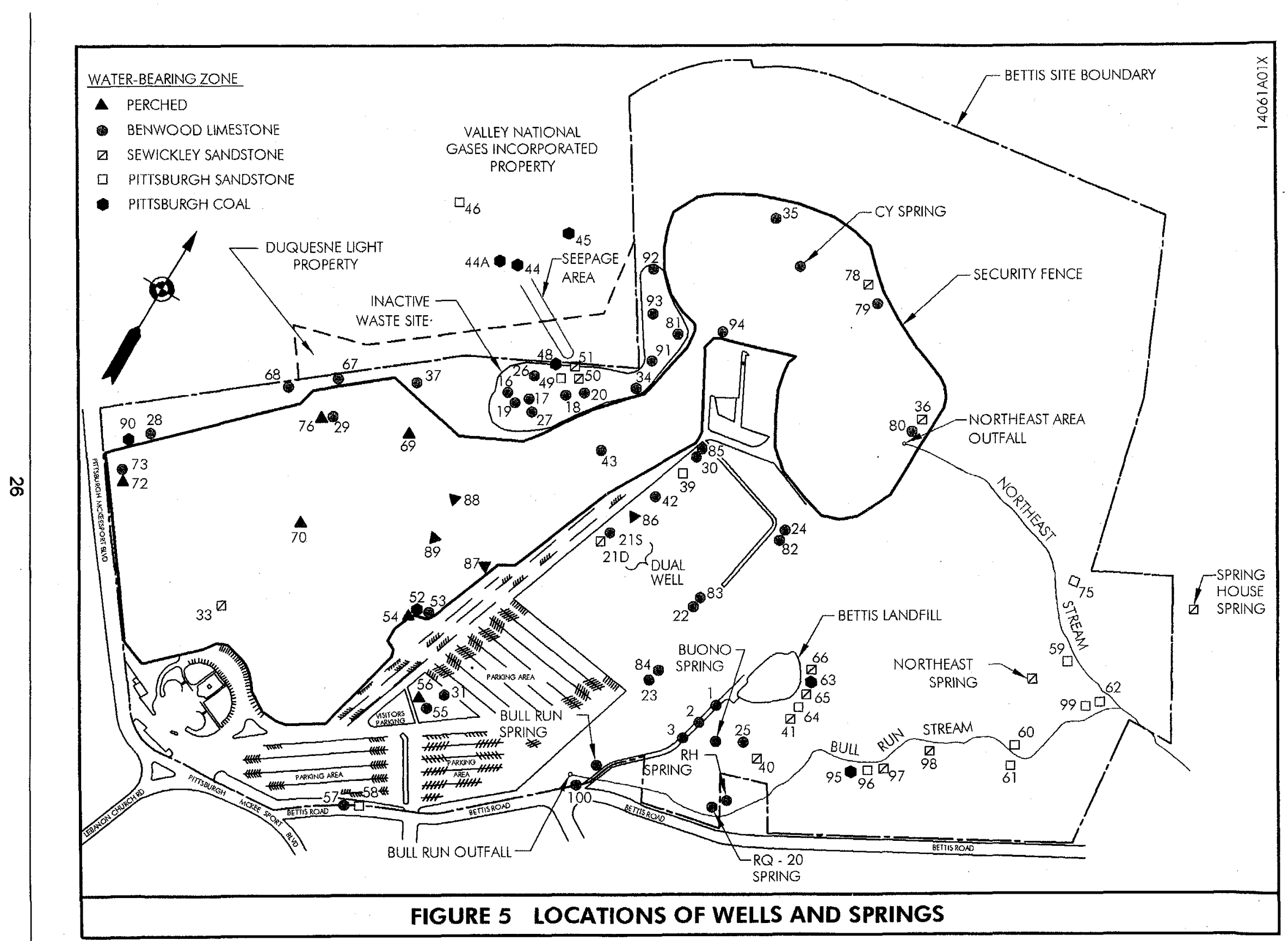


Bettis-Pittsburgh 1999 Environmental Monitoring Report

\section{Ground Water Analyses}

Radiological: Ground water analysis methods are discussed under Liquid Analyses in Section A.

Nonradiological: Analyses of ground water samples were performed using test methods described in Reference (3).

\section{Ground Water Monitoring Results and Conclusions}

Radiological: Tables $8 \mathrm{~A}-8 \mathrm{~F}$ present the radioactivity data for the ground water monitored in 1999.

The radioactivity data for the Perched Water-Bearing Zone are consistent with natural background levels of radioactivity in ground water in this area with the exception of Wells 88 and 89 around the Materials Evaluation Laboratory (MEL). Consistent with previous years, strontium-90 was detected in these wells, but was not detected in Well 87 in 1999. The level of strontium-90 detected in Well 88 was $0.71 \times 10^{-9} \mu \mathrm{Ci} / \mathrm{ml}$ and in Well 89 was $2.4 \times 10^{-9} \mu \mathrm{Ci} / \mathrm{ml}$, which is less than $1 \%$ of the limit of Reference (4) for strontium-90 in water in unrestricted areas. Wells 87,88 and 89 were installed at the recommendation of the Pennsylvania Department of Environmental Protection to monitor for migration of residual radioactivity from under the MEL. Historically, nine of the eleven wells monitoring the Perched Water-Bearing Zone have been sampled on at least one occasion for radioactivity. The remaining two wells have not contained sufficient water for sampling. The 1999 data do not show any increases in the ground water radioactivity levels. Overall, Bettis-Pittsburgh operations have not affected the natural radioactivity in the Perched Water-Bearing Zone.

The radioactivity data for the Benwood Water-Bearing Zone wells that were sampled in 1999 are consistent with typical natural background levels with the exception of the unenriched uranium results which were slightly higher than typical background levels for Well 73. Uranium has been handled at Bettis in both an unenriched form (that is, with the same uranium isotopic ratio as naturally occurring uranium) and in an enriched form (that is, with a higher uranium-235 isotopic ratio than naturally occurring uranium). Well 73 is located near the property boundary in a hydrologically upgradient portion of this zone, and is in an area of no known or suspected radiological contamination. It is also noted that Well 73 contains very little water and elevated solids content.

Well 72, located adjacent to but at a shallower depth, contains background uranium levels. The slightly elevated levels of unenriched uranium in Well 73 are, therefore, attributed to natural sources. Nonetheless, the uranium results for Well 73 are far below the limit in Reference (4) for uranium in water in unrestricted areas. Historically, 41 of 43 wells in the Benwood Zone have been sampled on at least one occasion for radioactivity and the results reported. The remaining two wells have not contained sufficient water for sampling. A review of the results from samples taken during previous years has shown that only Wells 17 and 18, located on the Inactive Waste Site, have been measurably affected by Bettis operations. Strontium-90 has been detected in Well 17 above background levels but well below the limit in Reference (4) for strontium-90 in water in unrestricted areas. Detectable levels of unenriched uranium in Wells 17 and 18, while above background concentrations, are well below the limit in Reference (4) for uranium in water in unrestricted areas. The presence and levels of these radionuclides are consistent with the low levels of residual radioactivity in soil in the Inactive Waste Site from past operations.

The radioactivity data for the Sewickley Sandstone Water-Bearing Zone wells that were sampled in 1999 are consistent with typical natural background levels except for the initial uranium results from Well 36 which were slightly higher than typical background levels. A review of site operations did not identify a source for these elevated levels. A second sample collected from Well 36 and a sample from Well 78, a nearby well in the same zone, showed uranium results at typical background levels and consistent with historical samples from these wells. Historically, all 13 wells in the Sewickley 
Zone have been sampled on at least one occasion and the results reported. A review of the results from samples taken during previous years has shown that Wells 78 and 21D have contained unenriched uranium at levels slightly above typical background levels. Since these wells are remote from areas likely affected by Bettis operations, the uranium is unenriched, and the uranium concentrations are near typical background levels, the detected uranium is considered to be from uranium naturally present in the soil. Bettis operations have not had a significant effect on the natural radioactivity in the Sewickley Sandstone Water-Bearing Zone.

The radioactivity data for the Pittsburgh Sandstone Water-Bearing Zone wells that were sampled in 1999 are consistent with natural background levels. Historically, nine of 12 wells in the Pittsburgh Sandstone Zone have been sampled on at least one occasion and the results reported. The remaining three wells have not contained sufficient water for sampling. A previous sample taken from Well 58 in 1994 contained unenriched uranium above normal background. Well 58 is remote from areas likely affected by Bettis operations and the uranium in this well was considered to be from natural sources. Nevertheless, the levels of natural uranium are well below the limits of Reference (4) for this activity in water in unrestricted areas. Bettis operations have not affected the natural radioactivity in the Pittsburgh Sandstone Water-Bearing Zone.

The radioactivity data for the Pittsburgh Coal Water-Bearing Zone wells that were sampled in 1999 are consistent with natural background levels with the possible exception of Wells 44 and 44A. Wells 44 and 44A monitor the Pittsburgh Coal Water-Bearing Zone within a few feet of each other. Well $44 \mathrm{~A}$ is set in a remaining coal pillar while Well 44 is set in a mined out void. The results from Wells 44 and $44 \mathrm{~A}$ indicate the presence of low levels of strontium- 90 in one of six samples. Strontium- 90 was also detected in Well 44 in 1996 and in Wells 44 and 44A in 1997 and 1998. The highest detected concentration was one-tenth the Reference (6) drinking water limit which is the most restrictive strontium-90 limit in water. Improvements in the strontium- 90 analysis procedure have allowed for the detection of the strontium-90 at these low levels. The levels of strontium-90 detected are similar to levels of strontium-90 which have been detected in ground water around the country and attributed to past atmospheric nuclear weapons testing. Strontium-90 is present in the soil in the Inactive Waste Site from past Bettis operations and higher than background levels of strontium- 90 have been detected in surface drainage from the Inactive Waste Site as discussed in past reports. It is not clear what part of the strontium-90 detected in Wells 44 and $44 \mathrm{~A}$ is due to the presence of strontium-90 from past atmospheric nuclear weapons testing. Samples will continue to be taken from this zone in 2000 to monitor for the presence of strontium-90. Historically, seven of the eight wells in this zone have been sampled on at least one occasion. The remaining well has not contained sufficient water for sampling. Overall, Bettis operations have not had a significant effect on the natural radioactivity in the Pittsburgh Coal Water-Bearing Zone.

Historically, some of the water in the abandoned Pittsburgh Coal Mine under the Site has discharged into the Borough of Dravosburg combined sanitary/storm sewer system. During 1998, the combined storm sewer system was modified so the discharge from the abandoned mine no longer enters the sanitary sewer system. Samples of this discharge were analyzed for radioactivity, and the results are in Table 8E as sample point DM176. The results are consistent with natural background levels of radioactivity and demonstrate that Site operations have not affected the natural radioactivity in this water.

The radioactivity data for the french drain discharges on the Inactive Waste Site and in the seepage on Duquesne Light and Valley National Gases properties are consistent with previous data and do not indicate any increase in the radioactivity levels. 
TABLE 8A

\begin{tabular}{|l|c|c|c|c|c|}
\hline \multicolumn{7}{|c|}{$\begin{array}{c}\text { GROUND WATER RADIOACTIVITY RESULTS } \\
\text { Perched Water Bearing Zone } \\
\text { Units: } 10^{-9} \mu \text { Ci/ml }\end{array}$} \\
\hline \multicolumn{7}{|c|}{ Sample Locations(1) } \\
\hline Analysis \\
Parameter & W70 & W72 & W87 & W88 & W89 \\
\hline Gross Alpha & $<8.9$ & $<4.2$ & $<7.2$ & $<10.0$ & $12 \pm 12$ \\
\hline Gross Beta & $<4.1$ & $<3.3$ & $11 \pm 5.3$ & $19 \pm 6.0$ & $18 \pm 5.8$ \\
\hline Strontium-90 & $<0.72$ & $<0.44$ & $<0.42$ & $0.71 \pm 0.35$ & $2.4 \pm 0.85$ \\
\hline Cesium-137 & $<6.6$ & $<4.2$ & $<6.1$ & $<6.4$ & $<4.0$ \\
\hline Cobalt-60 & $<5.4$ & $<3.9$ & $<6.0$ & $<5.8$ & $<3.4$ \\
\hline Uranium-233/234(2) & $0.64 \pm 0.33$ & $0.43 \pm 0.19$ & $0.83 \pm 0.41$ & $1.6 \pm 0.54$ & $0.24 \pm 0.14$ \\
\hline Uranium-235 & $<0.14$ & $<0.11$ & $<0.22$ & $<0.12$ & $<0.067$ \\
\hline Uranium-238 & $0.48 \pm 0.28$ & $<0.11$ & $0.37 \pm 0.27$ & $1.0 \pm 0.40$ & $0.24 \pm 0.14$ \\
\hline
\end{tabular}

NOTE: All notes for Table 8 can be found after Table $8 F$.

TABLE 8B

\section{GROUND WATER RADIOACTIVITY RESULTS Benwood Limestone Water Bearing Zone Units: $10^{-9} \mu \mathrm{Ci} / \mathrm{ml}$}

\begin{tabular}{|l|c|c|c|c|c|c|c||}
\hline & \multicolumn{7}{|c|}{ Units: $10^{-1} \mu \mathrm{Ci} / \mathrm{ml}$} \\
\cline { 2 - 9 } $\begin{array}{l}\text { Analysis } \\
\text { Parameter }\end{array}$ & W35 & W53 & W57 & W67 & W73 & W80 & W100 \\
\hline \hline Gross Alpha & $<3.6$ & $<11$ & $<15$ & $<7.6$ & $<7.2$ & $<4.3$ & $<8.9$ \\
\hline Gross Beta & $<3.2$ & $6.1 \pm 5.3$ & $<4.1$ & $5.2 \pm 5.1$ & $11 \pm 5.3$ & $<3.3$ & $5.5 \pm 5.2$ \\
\hline Strontium-90 & $<0.47$ & $<0.36$ & $<0.30$ & $<0.35$ & $<0.60$ & $<0.21$ & $<0.41$ \\
\hline Cesium-137 & $<7.0$ & $<7.3$ & $<6.3$ & $<6.8$ & $<4.7$ & $<6.5$ & $<5.7$ \\
\hline Cobalt-60 & $<5.5$ & $<5.5$ & $<5.6$ & $<5.6$ & $<4.3$ & $<5.7$ & $<4.8$ \\
\hline Uranium-233/234 & $<0.14$ & $<0.16$ & $1.2 \pm 0.51$ & $0.70 \pm 0.37$ & $6.9 \pm 1.5$ & $0.75 \pm 0.35$ & $<0.15$ \\
\hline Uranium-235 & $<0.23$ & $<0.14$ & $<0.24$ & $<0.17$ & $<0.12$ & $<0.14$ & $<0.13$ \\
\hline Uranium-238 & $<0.14$ & $0.33 \pm 0.23$ & $0.51 \pm 0.32$ & $0.43 \pm 0.29$ & $2.5 \pm 0.69$ & $0.32 \pm 0.22$ & $<0.10$ \\
\hline
\end{tabular}

NOTE: All notes for Table 8 can be found after Table $8 F$.

TABLE 8B (Continued)

\begin{tabular}{|c|c|c|c|c|c|}
\hline \multicolumn{6}{|c|}{$\begin{array}{l}\text { GROUND WATER RADIOACTIVITY RESULTS } \\
\text { Benwood Limestone Water Bearing Zone } \\
\text { Units: } 10^{-9} \mu \mathrm{Ci} / \mathrm{ml}\end{array}$} \\
\hline \multirow[b]{2}{*}{$\begin{array}{l}\text { Analysis } \\
\text { Parameter }\end{array}$} & \multicolumn{5}{|c|}{ Sample Locations ${ }^{(1)}$} \\
\hline & $\begin{array}{l}\text { Bull Run } \\
\text { Spring }\end{array}$ & $\begin{array}{l}\text { Buono } \\
\text { Spring }^{(3)}\end{array}$ & $\begin{array}{c}\text { RQ-20 } \\
\text { Spring }^{(3)}\end{array}$ & CY Spring & $\begin{array}{c}S^{S} S^{(3)} \\
\text { (Outfall 7) }\end{array}$ \\
\hline Gross Alpha & $<11.0$ & $<6.1$ & $<5.3$ & $<4.3$ & $<7.7$ \\
\hline Gross Beta & $5.6 \pm 5.3$ & $<3.6$ & $<3.5$ & $4.4 \pm 4.2$ & $7.5 \pm 5.2$ \\
\hline Strontium-90 & $<0.25$ & $<0.44$ & $<0.37$ & $<0.36$ & $<0.36$ \\
\hline Cesium-137 & $<6.2$ & $<5.7$ & $<7.0$ & $<6.0$ & $<7.0$ \\
\hline Cobalt-60 & $<5.7$ & $<5.2$ & $<5.5$ & $<5.4$ & $<5.9$ \\
\hline Uranium-233/234 & $2.0 \pm 0.87$ & $0.58=0.36$ & $0.56 \pm 0.26$ & $0.30 \pm 0.16$ & $0.74 \pm 0.40$ \\
\hline Uranium-235 & $<0.28$ & $<0.18$ & $<0.097$ & $<0.068$ & $<0.18$ \\
\hline Uranium-238 & $1.6 \pm 0.75$ & $0.36 \pm 0.28$ & $0.52 \pm 0.25$ & $0.11 \pm 0.091$ & $0.42 \pm 0.29$ \\
\hline
\end{tabular}

NOTE: All notes for Table 8 can be found after Table $8 F$. 
TABLE 8C

\begin{tabular}{|c|c|c|c|c|c|c|c|}
\hline \multicolumn{8}{|c|}{$\begin{array}{l}\text { GROUND WATER RADIOACTIVITY RESULTS } \\
\text { Sewickley Sandstone Water Bearing Zone } \\
\text { Units: } 10^{-9} \mu \mathrm{Ci} / \mathrm{ml}\end{array}$} \\
\hline \multirow[b]{2}{*}{$\begin{array}{l}\text { Analysis } \\
\text { Parameter }\end{array}$} & \multicolumn{7}{|c|}{ Sample Locations ${ }^{(1)}$} \\
\hline & \multicolumn{3}{|c|}{ W36 } & W51 & W78 & W98 & $\begin{array}{l}\text { Northeast } \\
\text { Spring }\end{array}$ \\
\hline Gross Alpha & $<5.2$ & $<4.3^{(5)}$ & $\overline{<5.4}$ & $<5.6$ & $16 \pm 13$ & $<4.3$ & $<5.0$ \\
\hline Gross Beta & $<3.5$ & $4.4 \pm 4.2$ & $<3.5$ & $5.1 \pm 4.6$ & $24 \pm 6.2$ & $<3.3$ & $9.2 \pm 4.7$ \\
\hline Strontium-90 & $<0.38$ & $<0.35$ & $<1.6$ & $<0.23$ & $<0.73$ & $<0.35$ & $<0.37$ \\
\hline Cesium-137 & $<6.5$ & $<7.0$ & $<5.2$ & $<4.8$ & $<6.0$ & $<6.4$ & $<6.8$ \\
\hline Cobalt-60 & $<5.2$ & $<5.9$ & $<4.8$ & $<3.9$ & $<6.0$ & $<5.4$ & $<5.4$ \\
\hline Uranium-233/234 & $4.2 \pm 1.1$ & $3.7 \pm 1.0$ & $1.8 \pm 0.46$ & $0.37 \pm 0.27$ & $2.3 \pm 0.58$ & $<0.15$ & $0.36 \pm 0.26$ \\
\hline Uranium-235 & $<0.23$ & $0.22 \pm 0.22$ & $<0.068$ & $<0.17$ & $<0.084$ & $<0.14$ & $<0.16$ \\
\hline Uranium-238 & $1.9 \pm 0.68$ & $1.8 \pm 0.64$ & $1.1 \pm 0.33$ & $0.32 \pm 0.25$ & $1.0 \pm 0.34$ & $<0.11$ & $0.29 \pm 0.22$ \\
\hline
\end{tabular}

NOTE: All notes for Table 8 can be found after Table $8 \mathrm{~F}$.

TABLE 8D

\begin{tabular}{|c|c|c|c|}
\hline \multicolumn{4}{|c|}{$\begin{array}{l}\text { GROUND WATER RADIOACTIVITY RESULTS } \\
\text { Pittsburgh Sandstone Water Bearing Zone } \\
\text { Units: } 10^{-9} \mathrm{\mu Ci} / \mathrm{ml}\end{array}$} \\
\hline \multirow{2}{*}{$\begin{array}{l}\text { Analysis } \\
\text { Parameter }\end{array}$} & \multicolumn{3}{|c|}{ Sample Locations ${ }^{(1)}$} \\
\hline & W46 & W60 & W96 \\
\hline Gross Alpha & $<<2.9$ & $17 \pm 11$ & $<4.5$ \\
\hline Gross Beta & $<3.0$ & $6.7 \pm 4.9$ & $<3.3$ \\
\hline Strontium-90 & $<0.36$ & $<0.45$ & $<0.41$ \\
\hline Cesium-137 & $<6.6$ & $<5.4$ & $<6.0$ \\
\hline Cobalt-60 & $<5.6$ & $<5.3$ & $<5.0$ \\
\hline Uranium-233/234 & $0.23 \pm 0.22$ & $0.74 \pm 0.39$ & $<0.20$ \\
\hline Uranium-235 & $<0.18$ & $<0.18$ & $<0.18$ \\
\hline Uranium-238 & $<0.20$ & $0.32 \pm 0.25$ & $<0.20$ \\
\hline
\end{tabular}

NOTE: All notes for Table 8 can be found after Table 8F.

TABLE 8E

\begin{tabular}{|c|c|c|c|c|c|c|c|c|c|}
\hline \multicolumn{10}{|c|}{$\begin{array}{c}\text { GROUND WATER RADIOACTIVITY RESULTS } \\
\text { Pittsburgh Coal Water Bearing Zone } \\
\text { Units: } 10^{-9} \mu \mathrm{Ci} / \mathrm{ml}\end{array}$} \\
\hline \multirow{2}{*}{$\begin{array}{l}\text { Analysis } \\
\text { Parameter }\end{array}$} & \multicolumn{9}{|c|}{ Sample Locations $^{(1)}$} \\
\hline & \multicolumn{3}{|c|}{$\overline{\text { W44 }}$} & \multicolumn{3}{|c|}{ W44A } & \multicolumn{3}{|c|}{$\overline{W 45}$} \\
\hline Gross Alpha & $7.1 \pm 6.7$ & $<4.5$ & $<4.1$ & $<4.6$ & $<4.7$ & $\overline{9.6 \pm 6.9}$ & $<3.0$ & $<3.4$ & $<3.3$ \\
\hline Gross Beta & $11.0 \pm 4.7$ & $7.1 \pm 4.4$ & $10 \pm 4.5$ & $8.4 \pm 4.5$ & $6.8 \pm 4.4$ & $9.3 \pm 4.5$ & $4.2 \pm 3.9$ & $5.6 \pm 4.1$ & $7.1 \pm 4.1$ \\
\hline Strontium-90 & $<0.38$ & $<0.43$ & $<0.42$ & $0.63 \pm 0.46$ & $<0.33$ & $<0.47$ & $<0.38$ & $<0.32$ & $<0.36$ \\
\hline Cesium-137 & $<6.0$ & $<5.9$ & $<4.5$ & $<5.4$ & $<6.3$ & $<3.9$ & $<5.8$ & $<5.5$ & $<4.6$ \\
\hline Cobalt-60 & $<6.2$ & $<4.5$ & $<4.0$ & $<5.3$ & $<5.7$ & $<3.3$ & $<5.0$ & $<5.3$ & $<4.2$ \\
\hline $\begin{array}{l}\text { Uranium- } \\
233 / 234^{(2)}\end{array}$ & $<0.12$ & $<0.19$ & $<0.14$ & $<0.18$ & $<0.19$ & $<0.14$ & $<0.21$ & $<0.18$ & $0.35 \pm 0.23$ \\
\hline Uranium-235 & $<0.19$ & $<0.15$ & $<0.17$ & $<0.17$ & $<0.17$ & $<0.17$ & $<0.18$ & $<0.17$ & $<0.19$ \\
\hline Uranium-238 & $<0.12$ & $<0.18$ & $<0.14$ & $<0.18$ & $<0.14$ & $<0.14$ & $<0.21$ & $<0.14$ & $<0.19$ \\
\hline
\end{tabular}

NOTE: All notes for Table 8 can be found after Table $8 \mathrm{~F}$. 
TABLE 8E (Continued)

\begin{tabular}{|c|c|c|c|c|c|c|}
\hline \multicolumn{7}{|c|}{$\begin{array}{l}\text { GROUND WATER RADIOACTIVITY RESULTS } \\
\text { Pittsburgh Coal Water Bearing Zone } \\
\text { Units: } 10^{-9} \mu \mathrm{Ci} / \mathrm{ml}\end{array}$} \\
\hline \multirow[b]{2}{*}{$\begin{array}{l}\text { Analysis } \\
\text { Parameter }\end{array}$} & \multicolumn{6}{|c|}{ Sample Locations ${ }^{(1)}$} \\
\hline & W48 $8^{(1)}$ & W52 & W63 & W95 & DM176 & $\begin{array}{c}\text { BKG }^{(4)} \\
\text { (Gasowski } \\
\text { Farm Well) }\end{array}$ \\
\hline Gross Alpha & $<4.9$ & $8.0 \pm 7.6$ & $<4.3$ & $<5.1$ & $8.4 \pm 7.1$ & $<4.0$ \\
\hline Gross Beta & $4.6 \pm 4.4$ & $7.0 \pm 4.6$ & $4.6 \pm 4.2$ & $7.7 \pm 4.6$ & $5.9 \pm 4.4$ & $12 \pm 4.6$ \\
\hline Strontium-90 & $<0.47$ & $<0.50$ & $<0.41$ & $<0.39$ & $<0.41$ & $<0.41$ \\
\hline Cesium-137 & $<7.3$ & $<6.8$ & $<6.2$ & $<6.7$ & $<6.4$ & $<5.8$ \\
\hline Cobalt-60 & $<5.8$ & $<5.5$ & $<5.5$ & $<5.8$ & $<5.3$ & $<5.4$ \\
\hline Uranium-233/234 $4^{(2)}$ & $<0.20$ & $0.42 \pm 0.30$ & $<0.19$ & $<0.20$ & $<0.21$ & $0.25 \pm 0.20$ \\
\hline Uranium-235 & $<0.18$ & $<0.18$ & $<0.17$ & $<0.21$ & $<0.18$ & $<0.14$ \\
\hline Uranium-238 & $<0.20$ & $0.28 \pm 0.24$ & $0.21 \pm 0.20$ & $<0.18$ & $0.25 \pm 0.20$ & $<0.13$ \\
\hline
\end{tabular}

NOTE: All notes for Table 8 can be found after Table $8 \mathrm{~F}$.

TABLE 8F

\section{GROUND WATER RADIOACTIVITY RESULTS Hillside Seepage Areas Units: $10^{-9} \mu \mathrm{Ci} / \mathrm{ml}$}

\begin{tabular}{|c|c|c|c|c|c|c|c|}
\hline \multirow{2}{*}{$\begin{array}{l}\text { Analysis } \\
\text { Parameter }\end{array}$} & \multicolumn{7}{|c|}{ Sample Locations ${ }^{(1)}$} \\
\hline & IW-01 & IW-02 & $\overline{D \text { DL-01 }}$ & 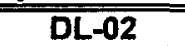 & VNGI-01 & $\overline{\text { VNGI-02 }}$ & VNGI-03 \\
\hline Gross Alpha & $\begin{array}{c}26 \pm 8.4 \\
\text { to } \\
29 \pm 8.6\end{array}$ & $120 \pm 14$ & $\begin{array}{c}<3.5 \\
\text { to } \\
12 \pm 7.7\end{array}$ & $12 \pm 8.1$ & $\begin{array}{c}15 \pm 7.2 \\
\text { to } \\
16 \pm 7.7\end{array}$ & $\begin{array}{c}<3.5 \\
\text { to } \\
15 \pm 8.5\end{array}$ & $<2.3$ \\
\hline Gross Beta & $\begin{array}{c}19 \pm 4.9 \\
\text { to } \\
21 \pm 5.0\end{array}$ & $78 \pm 7.3$ & $\begin{array}{c}6.0 \pm 4.1 \\
\text { to } \\
20 \pm 5.9\end{array}$ & $23 \pm 5.4$ & $\begin{array}{c}12 \pm 4.6 \\
\text { to } \\
19 \pm 5.0\end{array}$ & $\begin{array}{c}8.5 \pm 4.3 \\
\text { to } \\
25 \pm 5.5\end{array}$ & $<2.7$ \\
\hline Strontium-90 & $\begin{array}{c}<0.27 \\
\text { to } \\
0.52 \pm 0.4\end{array}$ & $\begin{array}{c}3.0 \pm \\
0.54\end{array}$ & $\begin{array}{c}2.2 \pm 0.65 \\
\text { to } \\
3.2 \pm 0.76\end{array}$ & $1.6 \pm 0.49$ & $\begin{array}{c}1.8 \pm 0.52 \\
\text { to } \\
2.1 \pm 0.54\end{array}$ & $\begin{array}{c}1.0 \pm 0.45 \\
\text { to } \\
2.4 \pm 0.64\end{array}$ & $<0.43$ \\
\hline Cesium-137 & $<6.2$ & $<6.1$ & $<6.8$ & $<5.7$ & $<6.1$ & $<6.4$ & $<6.4$ \\
\hline Cobalt-60 & $<5.8$ & $<5.8$ & $<5.7$ & $<4.4$ & $<5.6$ & $<5.9$ & $<5.6$ \\
\hline $\begin{array}{l}\text { Uranium- } \\
233 / 234^{(2)}\end{array}$ & $\begin{array}{c}21 \pm 3.8 \\
\text { to } \\
22 \pm 4.2\end{array}$ & $150 \pm 33$ & $\begin{array}{c}4.4 \pm 1.8 \\
\text { to } \\
6.0 \pm 1.6\end{array}$ & $9.7 \pm 2.2$ & $\begin{array}{c}5.3 \pm 1.3 \\
\text { to } \\
6.3 \pm 1.5\end{array}$ & $\begin{array}{c}1.5 \pm 0.83 \\
\text { to } \\
7.2 \pm 1.6\end{array}$ & $0.24 \pm 0.22$ \\
\hline Uranium-235 & $\begin{array}{c}0.79 \pm 0.39 \\
\text { to } \\
1.1 \pm 0.53\end{array}$ & $7.2 \pm 2.8$ & $\begin{array}{c}0.33 \pm 0.33 \\
\text { to } \\
<0.49\end{array}$ & $0.46 \pm 0.36$ & $\begin{array}{c}0.36 \pm 0.30 \\
\text { to } \\
0.45 \pm 0.31\end{array}$ & $\begin{array}{c}<0.34 \\
\text { to } \\
0.65 \pm 0.47\end{array}$ & $<0.18$ \\
\hline Uranium-238 & $\begin{array}{c}19 \pm 3.5 \\
\text { to } \\
20 \pm 4.0\end{array}$ & $147 \pm 32$ & $\begin{array}{c}4.2 \pm 1.7 \\
\text { to } \\
5.9 \pm 1.6\end{array}$ & $8.3 \pm 1.9$ & $\begin{array}{c}5.2 \pm 1.3 \\
\text { to } \\
6.9 \pm 1.6\end{array}$ & $\begin{array}{c}2.5 \pm 1.1 \\
\text { to } \\
6.9 \pm 1.8\end{array}$ & $<0.22$ \\
\hline
\end{tabular}

NOTES: (1) W48 = Monitoring Well No. 48; SIS = Springwater Intercept System; IW = Inactive Waste Site; DL = Duquesne Light; VNGI = Valley National Gases Inc.; DM176 = Sample of Pittsburgh Coal Mine water discharge into the Dravosburg storm sewer system.

(2) The analytical method cannot distinguish between U-233 and U-234. The results are attributed to U-234 based on the source of the radioactivity.

(3) These springs are included in the Springwater Intercept System. Samples were collected at access points in the drainage system. Some of the water discharging from the SIS also originates from the Sewickley Water Bearing Zone.

(4) $B K G=$ background. The water from this well is from the zone below the Pittsburgh Coal Water Bearing Zone but is considered to be representative of background water quality.

(5) Duplicate analysis of first sample from Well 36. 
The Inactive Waste Site water samples (Table 8F, IW-01 and IW-02) were collected from the discharges of a french drain shown in Figure 6. This water is probably from the Perched WaterBearing Zone that picks up low levels of radioactivity as it passes through the Inactive Waste Site. From the previous discussion, these results are not indicative of the Perched Water-Bearing Zone beneath the Site. The discharges from the drain are absorbed back into the ground within several feet of the discharge points and do not flow offsite over the surface. The radioactivity data show the presence of strontium-90 at $3.0 \times 10^{-9} \mu \mathrm{Ci} / \mathrm{ml}$ and uranium. The maximum levels of uranium were uranium-234, $1.5 \times 10^{-7} \mu \mathrm{Ci} / \mathrm{ml}$; uranium-235, $7.2 \times 10^{-9} \mu \mathrm{Ci} / \mathrm{ml}$, and uranium-238, $1.47 \times 10^{-7} \mu \mathrm{Ci} / \mathrm{ml}$.

Some of the water that migrates through the Inactive Waste Site also emerges occasionally in a wetweather drainage ditch on Duquesne Light and Valley National Gases properties and may flow as shown in Figure 6 if there is sufficient seepage. Most often, the water that emerges from the ditch is absorbed back into the ground before it reaches the locations of Wells 44 and 44A (Figure 5). The radioactivity data in Table $8 \mathrm{~F}$ show the presence of strontium-90 and uranium as noted in the liquid discharges from the french drain up gradient on the Inactive Waste Site. The maximum strontium- 90 concentration was $3.2 \times 10^{-9} \mu \mathrm{Ci} / \mathrm{ml}$. The maximum uranium concentrations were uranium-234, $9.7 \times$ $10^{-9} \mu \mathrm{Ci} / \mathrm{ml}$; uranium-235, $0.65 \times 10^{-9} \mu \mathrm{Ci} / \mathrm{ml}$ and uranium-238, $8.3 \times 10^{-9} \mu \mathrm{Ci} / \mathrm{ml}$.

The concentrations of radionuclides in the seepage on Duquesne Light and Valley National Gases properties are well below their Reference (4) limits for water in unrestricted areas. The strontium-90 levels are below the Reference (6) limit for drinking water. There is no current limit for uranium in drinking water. Based on the concentrations of the radionuclides and the fact that the ditch water is not consumed by humans, the presence of these low levels of radioactivity in the runoff does not pose a threat to humans.

In summary, the radiological operations at the Laboratory did not impact the ground water in 1999. A few wells and the seepage samples collected on and below the Inactive Waste Site contain low levels of radioactivity attributed to historical operations. The levels are all well below the limits of Reference (4). Overall, site operations have not significantly affected the natural radioactivity in the water-bearing zones under the Site.

Nonradiological: The results of the analyses of ground water for the chemical constituents of concern are presented in Tables $9 \mathrm{~A}$ and $9 \mathrm{~B}$. The results are summarized below.

Previous environmental monitoring results have shown that the contaminants-of-concern in Site ground water are volatile organic compounds, primarily tetrachloroethylene and its degradation products, trichloroethylene and trans-1, 2-dichloroethylene. Ground water samples analyzed during the RCRA Facility Investigation showed the following average total volatile organic compound level in the water-bearing zones: Perched-0.1 mg/l; Benwood Limestone-1.3 mg/l; Sewickley Sandstone-5.9 $\mathrm{mg} / \mathrm{l}$; and Pittsburgh Sandstone-0.065 mg/l. Volatile organic compounds associated with Site operations have not been detected above the analytical laboratory's minimum detection levels in the Pittsburgh Coal Water-Bearing Zone. The 1999 ground water monitoring results for volatile organic compounds are consistent with previous results.

Samples of seepage collected in the main wet-weather ditch (Figure 6) on Duquesne Light and Valley National Gases properties contained tetrachloroethylene, trichloroethylene and 1,2-dichloroethylene. The maximum levels of these compounds were $0.164,0.019$, and $0.017 \mathrm{mg} / \mathrm{l}$ respectively. These data are consistent with previous data and do not indicate any changes in the levels. 


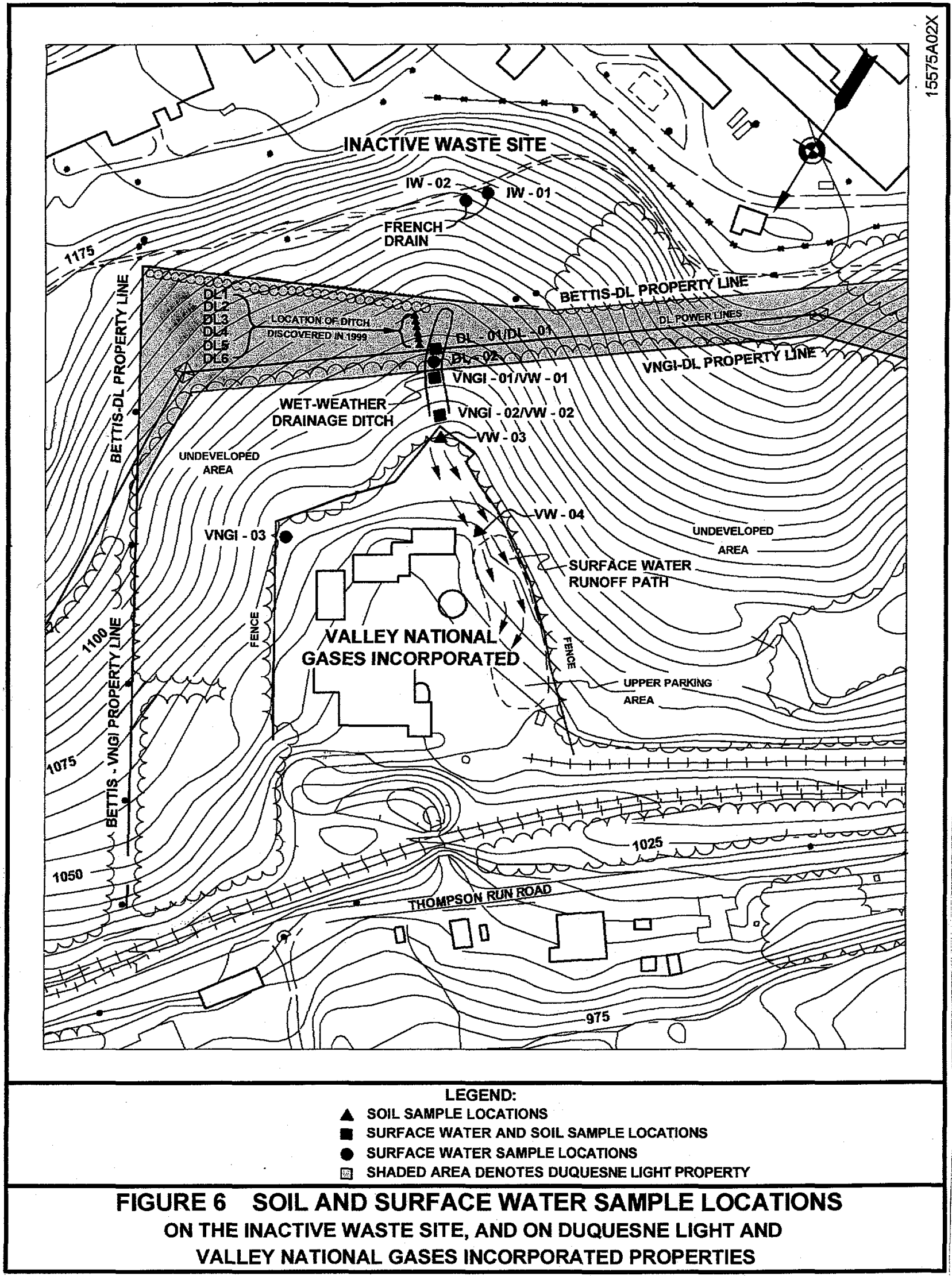


TABLE 9A

\begin{tabular}{|c|c|c|c|c|}
\hline \multicolumn{5}{|c|}{$\begin{array}{l}\text { GROUND WATER NONRADIOLOGICAL RESULTS } \\
\text { Units: } \mathrm{mg} / 1\end{array}$} \\
\hline \multirow{2}{*}{$\begin{array}{l}\text { WATER-BEARING } \\
\text { ZONE }\end{array}$} & \multirow{2}{*}{$\begin{array}{l}\text { WELL } \\
\text { NO. }\end{array}$} & \multicolumn{3}{|c|}{ ANALYSIS PARAMETERS ${ }^{(1)}$} \\
\hline & & PCE & TCE & DCE \\
\hline \multirow{5}{*}{ Perched } & 70 , & 0.026 & $0.005 \mathrm{~J}^{(2)}$ & 0.041 \\
\hline & 72 & $<0.005$ & $<0.005$ & $<0.005$ \\
\hline & 87 & $<0.005$ & $<0.005$ & $<0.005$ \\
\hline & 88 & 0.007 & $<0.005$ & $<0.005$ \\
\hline & 89 & 0.036 & 0.007 & 0.003 \\
\hline \multirow[t]{9}{*}{ Benwood } & 35 & $<0.005$ & $<0.005$ & $<0.005$ \\
\hline & 53 & $<0.005$ & $<0.005$ & 0.017 \\
\hline & 57 & $<0.005$ & $<0.005$ & $<0.005$ \\
\hline & 67 & $<0.005$ & $<0.005$ & $<0.005$ \\
\hline & 73 & $<0.005$ & $<0.005$ & $<0.005$ \\
\hline & 80 & $<0.005$ & $<0.005$ & $<0.005$ \\
\hline & 92 & $<0.005$ & $<0.005$ & $<0.005$ \\
\hline & 93 & 0.033 & 0.008 & 0.004 \\
\hline & 100 & $<0.005$ & $<0.005$ & $<0.005$ \\
\hline \multirow{4}{*}{ Sewickley Sandstone } & 36 & $<0.005$ & $0.003 \mathrm{~J}$ & $<0.005$ \\
\hline & 51 & 0.770 & 0.110 & 0.073 \\
\hline & 97 & $<0.005$ & $<0.005$ & $<0.005$ \\
\hline & 98 & $<0.005$ & $<0.005$ & $<0.005$ \\
\hline \multirow{5}{*}{ Pittsburgh Sandstone } & 46 & $0.004 \mathrm{~J}$ & $<0.005$ & $<0.005$ \\
\hline & 60 & 0.008 & $<0.005$ & $<0.005$ \\
\hline & 61 & $<0.005$ & $<0.005$ & $<0.005$ \\
\hline & 75 & $<0.005$ & $<0.005$ & $<0.005$ \\
\hline & 96 & $<0.005$ & $<0.005$ & $<0.005$ \\
\hline \multirow[t]{7}{*}{ Pittsburgh Coal } & 44 & $\begin{array}{l}<0.005 \\
<0.005\end{array}$ & $\begin{array}{l}<0.005 \\
<0.005\end{array}$ & $\begin{array}{l}<0.005 \\
<0.005\end{array}$ \\
\hline & $\overline{44 A}$ & $\begin{array}{l}<0.005 \\
<0.005\end{array}$ & $\begin{array}{l}<0.005 \\
<0.005\end{array}$ & $\begin{array}{l}<0.005 \\
<0.005\end{array}$ \\
\hline & 45 & $<0.005$ & $<0.005$ & $<0.005$ \\
\hline & 48 & $<0.005$ & $<0.005$ & $<0.005$ \\
\hline & 63 & $<0.005$ & $<0.005$ & $<0.005$ \\
\hline & 95 & $<0.005$ & $<0.005$ & $<0.005$ \\
\hline & DM176 & $<0.005$ & $<0.005$ & $<0.005$ \\
\hline
\end{tabular}

NOTE: All notes for Table 9 can be found after Table 9B.

\section{TABLE 9B}

\begin{tabular}{|c|c|c|c|}
\hline \multicolumn{4}{|c|}{$\begin{array}{c}\text { GROUND WATER NONRADIOLOGICAL RESULTS } \\
\text { DUQUESNE LIGHT AND VALLEY NATIONAL GASES } \\
\text { Hillside seepage Areas } \\
\text { Units: mg/l }\end{array}$} \\
\hline \multirow{3}{*}{ SAMPLE LOCATIONS } & \multicolumn{2}{|c|}{ ANALYSIS PARAMETERS } \\
\cline { 2 - 4 } & PCE & TCE & DCE \\
\hline DL-01 & 0.036 & $0.004 \mathrm{~J}^{(2)}$ & $0.003 \mathrm{~J}$ \\
\hline DL-02 & 0.164 & 0.019 & 0.017 \\
\hline VNGI-02 & 0.076 & 0.010 & 0.009 \\
\hline
\end{tabular}

NOTES:

(1)

Samples were analyzed for approximately 40 volatile organic compounds. Only the results for the potential contaminants-of-concern are reported. Results for the other volatile organic compounds were typically less than the minimum detection level, which was generally $0.005 \mathrm{mg} / \mathrm{l}$.

$\mathrm{PCE}=$ Tetrachloroethylene; $\mathrm{TCE}=$ Trichloroethylene; $\mathrm{DCE}=1,2$-Dichloroethylene

(2) $J=A n a l y t e$ present but reported value may not be accurate or precise.

(3) Sample of Pittsburgh Coal Mine discharge into the Dravosburg storm sewer system. 
Two wells near the site of a former gasoline underground storage tank were sampled to verify the long-term effects of the tank removal. Well 72, in the shallower, Perched Water-Bearing Zone, was found to have traces of gasoline residues (benzene, toluene, ethylbenzene, and xylene) in a sample obtained to characterize purge water but no such residues were found in the subsequent sample. Well 73, in the deeper, Benwood Water-Bearing Zone, did not contain nor has it ever contained any of the gasoline residues that have been detected in Well 72. The irregular detection of gasoline residues in Well 72 appears to be characteristic of the limited contamination in the soil following removal of the tank and associated soil. These data are consistent with previous data and do not indicate any changes in the levels or locations of these chemicals.

Some of the water in the abandoned Pittsburgh Coal Mine under the Site discharges into the Borough of Dravosburg storm sewer system. A sample (DM176) of this discharge was analyzed for volatile organic compounds. None of the volatile organic compounds associated with Site operations were detected in this discharge. This result is consistent with previous sample results.

The 1999 ground water monitoring results are consistent with previous results and they do not show any changes in the migration pattern of chemical residues in the ground water. 


\section{AIRBORNE EFFLUENTS}

The purpose of the airborne effluent monitoring program is to determine the effectiveness of control methods, to measure concentrations in effluents for comparison with applicable standards and natural background levels, and to assess the effect of any inadvertent releases to the environment.

\section{Sources}

Sources of radioactive airborne materials included operations associated with examining nuclear fuel and reactor materials. Areas of the Site wherein unencapsulated radioactive materials were handled were equipped with wet scrubbers or filtered exhaust systems. The high efficiency particulate air (HEPA) filters were preceded as necessary by prefilters to remove dust and large particulates. Charcoal filters were installed in select air handling systems to control potential gaseous radioactivity releases. HEPA filters were tested upon installation and at least annually thereafter to assure that high removal efficiencies $(99.95 \%)$ are maintained.

Sources of airborne effluents not related to radiological operations were heating systems, such as gas and oil fueled boilers and space heaters, and small-scale operations involving chemicals. Fuel burning and combustion equipment were operated in compliance with the Site's Air Operating Permit application. The Site's Air Operating Permit application was submitted to Allegheny County in November 1995 for air emissions at the Site. This application replaces the previous individual unit air operating permits. Issuance of the Site Air Operating Permit is anticipated in the near future. Air exhausted from the Site's fume hoods was treated, where appropriate, by filtration or wet scrubbers to minimize the release of materials.

\section{Airborne Monitoring}

The samples and analyses specified below constitute the minimum samples and analyses conducted at the Site during 1999.

Radiological: Radioactive airborne effluents from the Site were continuously monitored using fixedfilter air stations operated at a constant, metered sample flow rate. Particulate radioactivity in the effluents was collected on 0.8 micron millipore filters. Gaseous radionuclides, primarily iodine-131 and antimony-125, from appropriate exhausts were monitored using charcoal impregnated filters. Select exhausts were specifically monitored for plutonium-238, europium-152, uranium-233, cesium137, and strontium-90 as required by 40 CFR 61 Subpart $H$. Filters were collected and analyzed at least weekly for gross alpha and gross beta radioactivity with the exception of the filter from the LBuilding facility which was collected and analyzed quarterly. Additionally, the charcoal filters were analyzed for gamma-emitters. Quarterly, the particulate filters from each exhaust were composited and analyzed for gross alpha, gross beta, strontium-90, and gamma-emitters. In addition, sampling for the short half-life (55 seconds) radon-220 from former thorium handling areas was performed annually using a charcoal filter cold-trap method. The Site's radiological exhaust monitoring systems were in compliance with the EPA's requirements in Reference (7).

Background airborne particulate radioactivity was monitored continuously using fixed-filter air samplers positioned off-site at locations (Large, PA and West Mifflin, PA) which are approximately 5 miles and 1.5 miles, respectively, from the Site. These air filters were collected and analyzed weekly for gross alpha and gross beta radioactivity.

Nonradiological: There were no major chemical operations at the Site during 1999 which might generate significant quantities of airborne chemical pollutants. Estimates of particulate and gaseous 
emissions were used to ensure that applicable standards were met. Monitoring of nonradiological emissions was not required or necessary.

\section{Airborne Analyses}

Radiological: Particulate filter samples were analyzed for gross alpha and gross beta radioactivity at approximately 48 hours after collection to permit the decay of the naturally occurring, short-lived radon-thoron daughter products accumulated on the filters. The alpha and beta radioactivities were measured using a lead-shielded, gas-flow proportional counter. Quarterly, the sample filters were composited and analyzed for gross alpha and beta radioactivity as well as gamma-emitters. Typical minimum detection levels for gross alpha and beta radioactivity were $2.0 \times 10^{-16} \mu \mathrm{Ci} / \mathrm{ml}$ and $4.0 \times 10^{-16}$ $\mu \mathrm{Ci} / \mathrm{ml}$, respectively.

Gamma analyses were conducted using a high resolution Germanium-Lithium or Germanium detector and a multichannel analyzer. A typical minimum detection level for cesium-137 was $8.0 \times 10^{-16} \mu \mathrm{Ci} / \mathrm{ml}$. Uranium and plutonium analyses of selected composites were performed using alpha spectrometry. Typical detection levels for uranium-233 and plutonium-238 were $1.0 \times 10^{-16} \mu \mathrm{Ci} / \mathrm{ml}$ and $2.0 \times 10^{-16}$ $\mu \mathrm{Ci} / \mathrm{ml}$, respectively. In addition, strontium-90 analyses were performed on selected quarterly filter composites from potential source areas. A typical minimum detection level for strontium- 90 was $8.0 \times$ $10^{-16} \mu \mathrm{Ci} / \mathrm{ml}$.

Charcoal impregnated air filters were analyzed for gross alpha and gross beta radioactivity and for specific gamma-emitting radionuclides. Gamma analyses were performed using a GermaniumLithium or Germanium gamma spectrometry system. A typical minimum detection level for gaseous iodine-131 was $2.0 \times 10^{-14} \mu \mathrm{Ci} / \mathrm{ml}$.

The charcoal filters used for measuring radon-220 releases were analyzed using the high resolution Germanium-Lithium or Germanium detector. The radon-220 concentrations were determined from the characteristic photo-peak of lead-212 which is the principal gamma-emitting product of radon-220 decay.

Nonradiological: Discharges of nonradioactive airborne pollutants were not significant enough to require airborne monitoring. Estimates of emissions were performed, as necessary, to ensure that applicable standards were met.

\section{Airborne Monitoring Results and Conclusions}

Radiological: The results of the monitoring of particulate and gaseous radioactivity effluents from the Site during 1999 are summarized in Table 10. Specific results from the airborne monitoring program are discussed below. Although comparisons of the Site's particulate airborne radioactivity results were made to background particulate radioactivity levels measured at off-site locations, no background corrections were made to the Site's release results.

The average concentration of airborne particulate gross alpha radioactivity released during 1999 was less than $6.55 \times 10^{-16} \mu \mathrm{Ci} / \mathrm{ml}$ and the average concentration of airborne particulate gross beta radioactivity was less than $2.64 \times 10^{-15} \mu \mathrm{Ci} / \mathrm{ml}$. In comparison, the average background gross alpha and gross beta airborne particulate radioactivity measured at the off-site locations were $1.58 \times 10^{-15}$ $\mu \mathrm{Ci} / \mathrm{ml}$ and $2.29 \times 10^{-14} \mu \mathrm{Ci} / \mathrm{ml}$, respectively. Thus, on average, the gross alpha airborne radioactivity concentration in air emitted from the Site was less than two times the background airborne radioactivity levels. The gross beta airborne particulate radioactivity concentration in air emitted from 
the Site was approximately nine times less than background airborne radioactivity levels due to the Site's filtration systems on the radiological exhausts.

There were no detectable releases of uranium-233, plutonium-238 and europium-152 during 1999. The concentrations of these radionuclides listed in Table 10 are based on the minimum detection levels of the analyses. The majority of the cesium-137 results were also less than the minimum detection level, but cesium-137 was detected in the effluent from one facility at a maximum concentration of $1.4 \times 10^{-15} \mu \mathrm{Ci} / \mathrm{ml}$; this value is well below the Federal limit of $2.0 \times 10^{-10} \mu \mathrm{Ci} / \mathrm{ml}$.

TABLE 10

\begin{tabular}{||l|c|c||}
\hline \multicolumn{3}{|c|}{ AIRBORNE EFFLUENT RADIOACTIVITY RESULTS(1) } \\
\hline Activity & $\begin{array}{c}\text { Average } \\
\text { Concentration } \\
\text { At Release Point } \\
(\mu \mathrm{Ci})\end{array}$ & $\begin{array}{c}\text { Limit } \\
\text { At Site Boundary } \\
(\mu \mathrm{Ci} / \mathrm{ml})\end{array}$ \\
\hline \hline Effluent Gross Alpha & $\leq 6.55 \mathrm{E}-16$ & $6.0 \mathrm{E}-15^{(4)}$ \\
\hline Background Gross Alpha & $\leq 1.58 \mathrm{E}-15$ & $3.0 \mathrm{E}-11^{(5)}$ \\
\hline Effluent Gross Beta & $\leq 2.64 \mathrm{E}-15$ & $2.0 \mathrm{E}-14$ \\
\hline Background Gross Beta & $\leq 2.29 \mathrm{E}-14$ & $3.0 \mathrm{E}-11$ \\
\hline Plutonium-238 & $<1.4 \mathrm{E}-16$ & $5.0 \mathrm{E}-14$ \\
\hline Europium-152 & $<3.4 \mathrm{E}-15$ & $2.0 \mathrm{E}-10$ \\
\hline Uranium-233 & $<2.4 \mathrm{E}-16$ & \\
\hline Cesium-137 & $\leq 6.5 \mathrm{E}-16$ & \\
\hline
\end{tabular}

NOTES: (1) For radioactivity with half-lives greater than one day.

(2) < signifies the data are below the minimum detection level.

(3) Nuclear Regulatory Commission limits as prescribed in Title 10, Code of Federal Regulations, Part 20 for air in uncontrolled regions.

(4) Based on thorium-232.

(5) Based on strontium-90.

There were no detectable releases of gaseous radioactivity, such as antimony-125 and iodine-131, with half-lives greater than one day. During 1999, there were no operations conducted which would have generated these types of gaseous radioactivity or other long-lived gaseous radionuclides with half-lives greater than one day such as krypton- 85 .

Based on the results of radon-220 effluent measurements and pathway evaluations, the average concentration of radon-220 at the location of the nearest off-site receptors was estimated to be approximately $4.9 \times 10^{-12} \mu \mathrm{Ci} / \mathrm{ml}$. This level is below the Federal limit of $3.0 \times 10^{-11} \mu \mathrm{Ci} / \mathrm{ml}$ for radon220 in the air of uncontrolled areas. The releases of the very short-lived (55 seconds) radon-220 gaseous radioactivity from the Site resulted in no adverse effect on the surrounding environment and did not result in radiation exposures above the EPA and DOE radiation dose standards.

The total airborne radioactivity released from the Site with radionuclide decay half-lives greater than one day was less than $0.00000167\left(1.67 \times 10^{-6}\right)$ Curie.

The results of the Site's airborne radiological effluent monitoring program demonstrate the effectiveness of control methods. The results also show that the amount of airborne radioactivity released was too small to result in any measurable change in the background radioactivity levels in the environment. The concentrations of radioactivity released from the Site during 1999 were below the applicable limits for radioactivity in ambient air. Furthermore, the estimated radiation dose to any 
member of the public from the airborne radioactivity released was too low to measure and was significantly below the radiation protection standard established by the EPA in Reference (7).

Nonradiological: The results of evaluations and calculations for the Site's sources of airborne chemical pollutants are summarized below.

\section{Heating System Exhaust}

The boilers and space heating systems at the Site were fueled with natural gas and Number 2 distillate fuel oil. The heating systems were operated in accordance with the Allegheny County Health Department, Article XXI, Air Pollution Control regulations. Conservative estimates of the pollutant releases utilizing EPA emission factors were made. These calculations showed that the airborne emissions from the Site's heating systems are well below the applicable local limits identified in Reference (8).

\section{Exhausts from Site Fume Hoods}

Chemical vapors discharged by the Site's fume hoods were similar to those from other research labs engaged in analytical chemistry and development efforts. On the basis of the small scale of the operations, the types of material handled, and the treatment provided, it was concluded that the Site fume hood exhausts did not have any adverse effect on the environment.

\section{Asbestos Removal Work}

Asbestos removal work was conducted in compliance with the Federal, State and local requirements to limit the potential discharge of asbestos fibers to the environment. During 1999, the Allegheny County Health Department conducted 28 clearance inspections of asbestos abatement projects and passed all areas for release of the work area to the public. 


\section{SEDIMENT, SOIL, AND VEGETATION}

The purpose of the sediment and soil monitoring programs is to monitor for the migration of existing radioactive and chemical residues. The purpose of the stream vegetation radiological monitoring program is to monitor for the uptake of radioactivity into stream vegetation.

\section{Sources}

The source of the radioactive and chemical residues in portions of the storm drain system and the Bull Run Stream basin is from operations conducted in the 1950's and 1960's. A significant amount of contaminated soil along Bull Run was removed many years ago and disposed of off-site at a DOE burial ground.

The source of soil contamination on portions of Duquesne Light and Valley National Gases properties immediately downgrade of the Bettis Inactive Waste Site is from residual chemical and radioactive contaminants in the Inactive Waste Site.

\section{Sediment, Soil, and Vegetation Monitoring}

Radiological: Routine sediment samples were collected semiannually from the streambeds of the Site's effluent streams and from an off-site control stream, as shown in Figure 7 . Seven sediment samples were collected along the length of the Bull Run and Thompson Run Streams. One sample each was collected from the Northeast Area Stream, and the Streets Run Stream. The sediment sample from the Streets Run Stream is a background sample since there are no known nuclear or radiological facilities in operation which could release radioactive effluents to this stream.

In addition, sediment samples were collected from the catch basins at the Bull Run and Northeast Area Monitoring Stations and from storm drain components upstream of the Bull Run and Northeast Area Monitoring Stations (Manholes 10.2 and 70.1, and Yard Drain 8.1E); these sample locations are shown in Figure 7. Sediment samples were analyzed for gross alpha and gross beta radioactivity, strontium-90, and gamma-emitters. Some samples were also analyzed for uranium.

No soil samples were collected from the main drainage ditch since they are only collected every two years. Soil samples were collected from a secondary wet-weather drainage ditch on Duquesne Light property immediately downgrade of the Bettis Inactive Waste Site. This ditch is east of the main wetweather drainage ditch, shown in Figure 6, that is routinely sampled. This ditch was identified in 1999 after Duquesne Light removed standing vegetation along their power lines. These samples were analyzed for gross alpha and gross beta radioactivity, gamma emitters, and uranium isotopes.

Vegetation samples were collected annually from select locations in and along the Site's effluent streams. The vegetation samples were analyzed for strontium-90 activity and gamma-emitters.

Nonradiological: Sediment samples were collected annually from the catch basins at the Bull Run and Northeast Area Monitoring Stations and from select storm drain components, as shown in Figure 7. The sediment samples were analyzed for polychlorinated biphenyls, volatile organic compounds, and mercury.

Sediment samples were collected annually from two locations (BR1 and BR5) in the Bull Run Stream, as shown in Figure 4. These samples were analyzed for volatile organic compounds and polychlorinated biphenyls in 1999. 


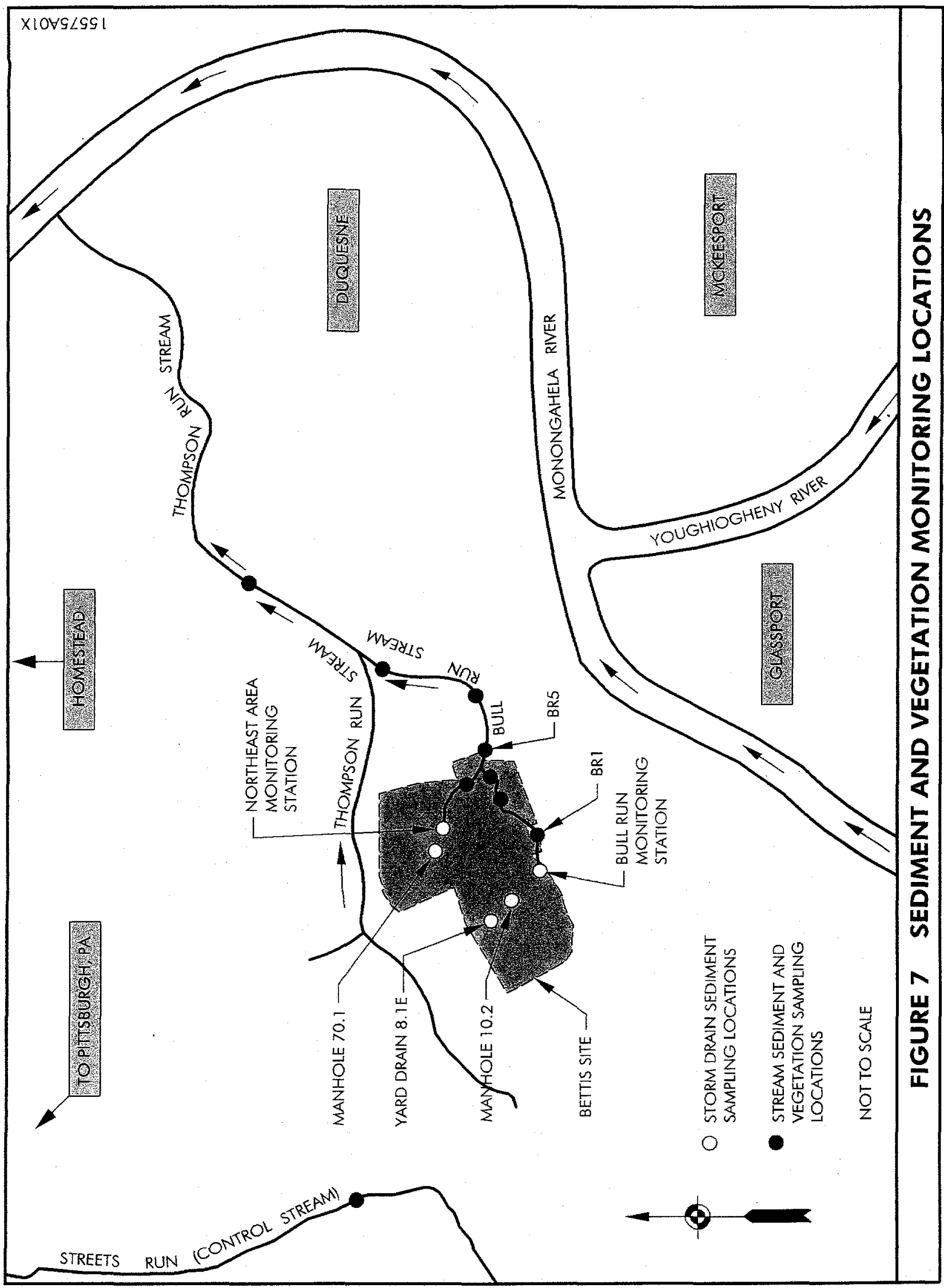


Soil samples were collected annually from the main wet-weather ditch, downgrade of the Bettis Inactive Waste Site, on Duquesne Light and Valley National Gases properties, as shown in Figure 6. These samples were analyzed for polychlorinated biphenyls, polynuclear aromatic hydrocarbons, and volatile organic compounds.

Soil samples were also collected from a secondary wet-weather drainage ditch that was identified on Duquesne Light property in 1999, as shown in Figure 6. These samples were analyzed for polychlorinated biphenyls, polynuclear aromatic hydrocarbons, and volatile organic compounds.

\section{Sediment, Soil, and Vegetation Analyses}

Radiological: The sediment samples were oven-dried, milled, homogenized, and screened to remove large stones and extraneous materials. The vegetation samples were air dried, chipped, and blended. Aliquots of the homogenized sediment samples were uniformly distributed on a planchet and the alpha and beta radioactivities were measured by counting the dried samples using a lead shielded, gas-flow proportional counter. Gamma analyses were performed on the sediment and vegetation by counting the dried samples with a gamma spectrometry system. Typical minimum detection levels for the gamma analyses were $0.1 \mathrm{pCi} / \mathrm{g}$ for sediment and $0.03 \mathrm{pCi} / \mathrm{g}$ for vegetation samples.

Strontium-90 analyses of the samples were performed utilizing a standard strontium radiochemical procedure. The strontium was chemically separated and the sample was counted for beta radioactivity using the low background proportional counter described above. Typical minimum detection levels for strontium-90 ranged from $0.1-0.3 \mathrm{pCi} / \mathrm{g}$.

Nonradiological: Analysis of sediments and soils were performed using test methods described in Reference (3).

\section{Sediment, Soil, and Vegetation Monitoring Results and Conclusions}

Radiological: The results of the radioactivity analyses of sediments and vegetation are summarized in Tables 11 and 12.

The alpha and beta radioactivity levels in the Bull Run Stream, Thompson Run Stream and the Northeast Area Stream sediment samples were consistent with the alpha and beta radioactivity levels in the background (Streets Run) stream sediment.

Low levels of cesium-137 radioactivity, up to a maximum concentration of $2.7 \mathrm{pCi} / \mathrm{g}$, were detected in the sediment samples from the Bull Run and Thompson Run Streams. This radioactivity is from effluent releases which occurred more than 30 years ago. The radioactivity levels for cobalt-60 and strontium-90 in the sediment from the Bull Run, Thompson Run and the Northeast Area Streams were below minimum detection levels and were consistent with background radioactivity levels.

Radioactivity levels in vegetation collected in the Site's effluent streams and Thompson Run Stream were consistent with background radioactivity levels in vegetation.

In summary, the data did not indicate any uptake of residual radioactivity in stream vegetation or any significant changes in the residual radioactivity levels in stream sediments.

The results of the sediment samples taken from the storm drain system show the presence of low-

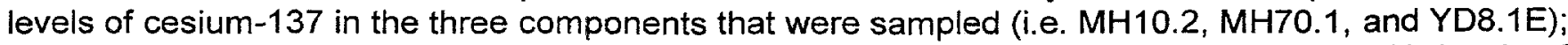
the cesium-137 results ranged from 0.34 to $0.71 \mathrm{pCi} / \mathrm{g}$. These values are consistent with levels of 
cesium-137 found throughout the environment due to fallout from past atmospheric nuclear weapons testing. The low-level uranium in manhole 70.1 (see Table 11) is from historical operations. Manhole 70.1 is upstream of the Northeast Area Monitoring Station. The sample results from the monitoring station and from the Northeast Area Stream do not indicate that the uranium in manhole 70.1 has migrated to or beyond the monitoring station. The sample results from the Bull Run Monitoring Station did not indicate the presence of Bettis radioactivity.

TABLE 11

\section{STORM DRAIN AND STREAM SEDIMENT RADIOACTIVITY RESULTS(I)} Units: pCi/g

\begin{tabular}{|c|c|c|c|c|c|c|c|c|}
\hline \multirow[b]{2}{*}{$\begin{array}{l}\text { Sample } \\
\text { Location }\end{array}$} & \multicolumn{8}{|c|}{ Analyses } \\
\hline & $\begin{array}{l}\text { Gross } \\
\text { Alpha }\end{array}$ & $\begin{array}{l}\text { Gross } \\
\text { Beta }\end{array}$ & $\begin{array}{c}\text { Gross } \\
\text { Strontium } \\
-90\end{array}$ & $\begin{array}{l}\text { Cesium- } \\
\qquad 137\end{array}$ & $\begin{array}{c}\text { Cobalt- } \\
60\end{array}$ & $\begin{array}{l}\text { Uranium- } \\
233 / 234^{(2)}\end{array}$ & Uranium-235 & $\begin{array}{l}\text { Uranium- } \\
238\end{array}$ \\
\hline $\begin{array}{l}\text { Bull Run' } \\
\text { Thompson } \\
\text { Run Streams }\end{array}$ & $\begin{array}{c}4.6 \pm 4.1 \\
\text { to } \\
17 \pm 6.0\end{array}$ & $\begin{array}{c}19 \pm 4.0 \\
\text { to } \\
35 \pm 4.6\end{array}$ & $<1.0$ & $\begin{array}{c}<0.071 \\
\text { to } \\
2.7 \pm 0.26\end{array}$ & $\begin{array}{c}<0.054 \\
\text { to } \\
<0.19\end{array}$ & $\begin{array}{c}0.45 \pm 0.20 \\
\text { to } \\
1.2 \pm 0.38\end{array}$ & $\begin{array}{c}<0.053 \\
\text { to } \\
0.57 \pm 0.57\end{array}$ & $\begin{array}{c}0.45 \pm 0.28 \\
\text { to } \\
0.91 \pm 0.32\end{array}$ \\
\hline $\begin{array}{l}\text { Northeast Area } \\
\text { Stream }\end{array}$ & $\begin{array}{c}9.2 \pm 5.2 \\
\text { to } \\
16 \pm 5.8\end{array}$ & $\begin{array}{c}24 \pm 4.4 \\
\text { to } \\
25 \pm 3.9\end{array}$ & $<1.0$ & $\begin{array}{c}<0.070 \\
\text { to } \\
<0.21\end{array}$ & $\begin{array}{c}<0.070 \\
\text { to } \\
<0.22\end{array}$ & $\begin{array}{c}0.72 \pm 0.27 \\
\text { to } \\
0.94 \pm 0.30\end{array}$ & $\begin{array}{c}<0.074 \\
\text { to } \\
0.087 \pm 0.087\end{array}$ & $\begin{array}{c}0.44 \pm 0.19 \\
\text { to } \\
0.45 \pm 0.20\end{array}$ \\
\hline $\begin{array}{l}\text { Background } \\
\text { (Streets Run } \\
\text { Stream) }\end{array}$ & $\begin{array}{c}8.5 \pm 4.6 \\
\text { to } \\
10 \pm 5.0\end{array}$ & $\begin{array}{c}18 \pm 3.0 \\
\text { to } \\
26 \pm 3.8\end{array}$ & $<1.0$ & $\begin{array}{c}<0.066 \\
\text { to } \\
<0.15\end{array}$ & $\begin{array}{c}<0.070 \\
\text { to } \\
<0.17\end{array}$ & $\begin{array}{c}0.28 \pm 0.24 \\
\text { to } \\
0.43 \pm 0.20\end{array}$ & $\begin{array}{c}<0.074 \\
\text { to } \\
<0.18\end{array}$ & $\begin{array}{c}0.38 \pm 0.28 \\
\text { to } \\
0.42 \pm 0.20\end{array}$ \\
\hline $\begin{array}{l}\text { Bull Run } \\
\text { Monitoring } \\
\text { Station }\end{array}$ & $6.3=4.5$ & $14 \pm 3.3$ & $<0.21$ & $<0.031$ & $<0.032$ & $N M^{(3)}$ & $<0.17$ & $<0.44$ \\
\hline $\begin{array}{l}\text { Northeast Area } \\
\text { Monitoring } \\
\text { Station }\end{array}$ & $7.3 \pm 4.8$ & $19 \pm 3.9$ & $<0.28$ & $<0.030$ & $<0.028$ & NM & $<0.12$ & $1.2 \pm 0.6$ \\
\hline MH 10.2 & $26 \pm 7.2$ & $40 \pm 5.0$ & $<0.23$ & $0.71 \pm 0.05$ & $<0.016$ & NM & $0.14 \pm 0.05$ & $1.2 \pm 0.4$ \\
\hline MH 70.1 & $\begin{array}{c}210 \pm 18 \\
\text { to } \\
280 \pm 20\end{array}$ & $\begin{array}{c}65 \pm 5.4 \\
\text { to } \\
67 \pm 5.5\end{array}$ & $<0.3$ & $0.34 \pm 0.07$ & NM & 48 to 123 & 1.7 to 7.9 & 3.4 to 16 \\
\hline YD 8.1E & $21 \pm 9.5$ & $37 \pm 11$ & $<0.21$ & $0.70 \pm 0.15$ & $<0.067$ & NM & $<0.29$ & $<0.79$ \\
\hline
\end{tabular}

NOTES: (1) < signifies the data are below the minimum detection level.

(2) The analytical method cannot distinguish between U233 and U234. The results are attributed to U234 based on the source on the radioactivity.

(3) $\quad \mathrm{NM}=$ Not Measured

TABLE 12

\begin{tabular}{||c|c|c|c||}
\hline \multicolumn{3}{|c|}{ STREAM VEGETATION RADIOACTIVITY RESULTS } \\
Units: pCi/g \\
\hline $\begin{array}{c}\text { Sample } \\
\text { Location }\end{array}$ & \multicolumn{3}{|c|}{ Analyses } \\
\cline { 2 - 4 } & Strontium-90 & Cobalt-60 & Cesium-137 \\
\hline \hline \multirow{3}{*}{ Bull Run/Thompson Run } & $<0.047$ & $<0.016$ & $<0.016$ \\
& to & to & to \\
& $0.11 \pm 0.092$ & $<0.099$ & $0.36 \pm 0.19$ \\
\hline Northeast Area & $<0.069$ & $<0.030$ & $<0.026$ \\
\hline Background & $<0.065$ & $<0.024$ & $<0.018$ \\
\hline
\end{tabular}

NOTE: $\quad(1)<$ signifies the data are below the minimum detection level 
The results of the soil samples from the secondary wet-weather drainage ditch on Duquesne Light property are provided in Table 13, and the sample locations are shown in Figure 6. The soil samples contain low levels of cesium-137 and uranium. The maximum concentrations of these isotopes are cesium-137, $1.7 \mathrm{pCi} / \mathrm{g} ; \mathrm{U}-233 / 234,1.2 \mathrm{pCi} / \mathrm{g} ; \mathrm{U}-235$, not detected; and U-238, $1.2 \mathrm{pCi} / \mathrm{g}$. These radioactivity levels are consistent with levels previously found in the main wet-weather drainage ditch and show that there has not been any buildup of radioactivity in the area in the last several years. The radiation dose that could be incurred from the radioactivity in the soil is well less than the limit of reference (4) and does not realistically present any increased carcinogenic risk to Duquesne Light personnel.

TABLE 13

\begin{tabular}{|c|c|c|c|c|c|c|c|}
\hline \multicolumn{8}{|c|}{$\begin{array}{c}\text { DUQUESNE LIGHT } \\
\text { SOIL RADIOLOGICAL RESULTS } \\
\text { Units: pci/g }\end{array}$} \\
\hline \multirow[b]{2}{*}{$\begin{array}{l}\text { SAMPLE } \\
\text { LOCATION }\end{array}$} & \multicolumn{7}{|c|}{ Analyses } \\
\hline & Gross Alpha & Gross Beta & Cesium-137 & Cobalt-60 & $\begin{array}{l}\text { Uranium- } \\
233 / 234^{(2)}\end{array}$ & Uranium-235 & $\begin{array}{l}\text { Uranium- } \\
238\end{array}$ \\
\hline DL-01 & $5.9 \pm 4.9$ & $27 \pm 5.0$ & $1.7 \pm 0.25$ & $<0.056$ & $0.62 \pm 0.27$ & $<0.091$ & $0.21 \pm 0.15$ \\
\hline $\mathrm{DL}-02$ & $6.2 \pm 4.7$ & $32 \pm 4.6$ & $1.6 \pm 0.18$ & $<0.069$ & $0.42 \pm 0.19$ & $<0.092$ & $0.35 \pm 0.17$ \\
\hline DL-03 & $7.1 \pm 4.9$ & $30 \pm 4.6$ & $1.3 \pm 0.15$ & $<0.060$ & $0.59 \pm 0.20$ & $<0.048$ & $0.48 \pm 0.18$ \\
\hline DL-04 & $13 \pm 5.8$ & $31 \pm 4.9$ & $1.4 \pm 0.15$ & $<0.072$ & $0.64 \pm 0.29$ & $<0.092$ & $0.55 \pm 0.26$ \\
\hline DL-05 & $13 \pm 5.6$ & $32 \pm 4.5$ & $1.3 \pm 0.17$ & $<0.075$ & $0.67 \pm 0.28$ & $<0.090$ & $0.46 \pm 0.20$ \\
\hline DL-06 & $8.6 \pm 5.3$ & $33 \pm 5.1$ & $1.6 \pm 0.16$ & $<0.060$ & $1.2 \pm 0.38$ & $<0.084$ & $1.2 \pm 0.39$ \\
\hline
\end{tabular}

Notes: (1) The reported results represent the maximum results where more than one sample was analyzed from a sample location.

(2) The analytical method cannot distinguish between $U-233$ and $U-234$. The results are attributed to $U-234$ based on the source of the radioactivity.

Nonradiological: The results of the nonradiological soil and sediment samples collected and analyzed in 1999 are provided below.

Table 14 provides the results for the primary chemicals of concern for the soil samples collected on Duquesne Light and Valley National Gases properties immediately below the Inactive Waste Site. The sample locations are shown in Figure 6.

The soil sample results from the main wet-weather drainage ditch show the same chemical residues as reported in the RCRA Facility Investigation, Reference (1). The volatile organic compound detected in the highest concentration was tetrachloroethylene at $1.8 \mathrm{mg} / \mathrm{kg}$ and this result is consistent with previous results. Several polynuclear aromatic hydrocarbons (PAH) were detected in the soil samples. The PAH compound of interest, benzo(a) pyrene, was detected at $4.0 \mathrm{mg} / \mathrm{kg}$ at the top of the drainage ditch. The concentration of this and other PAH compounds are consistent with previous results reported in Reference (1). The PAH compounds detected are consistent with anthropogenic background (i.e. man-made background) PAH compounds in the vicinity of the Site. Polychlorinated biphenyl (PCB) results were consistent with previous results. The maximum concentration detected was $8.2 \mathrm{mg} / \mathrm{kg}$ of PCB-1260.

The results of the soil samples from the secondary drainage ditch on Duquesne Light property are also provided in Table 14. None of the primary volatile organic compounds of concern were detected in the soil samples above the analytical laboratory's minimum detection level of approximately 0.010 $\mathrm{mg} / \mathrm{kg}$. Trace amounts of polychlorinated biphenyls to a maximum of $0.036 \mathrm{mg} / \mathrm{kg}$ were measured in 
three of the six samples. Several polynuclear aromatic hydrocarbons were detected in the soil samples. The PAH compounds of interest, benzo(a)prene was detected at a maximum level of 0.450 $\mathrm{mg} / \mathrm{kg}$. The concentration of this and other PAH compounds are consistent with anthropogenic background PAH compounds in the vicinity of the Site.

In summary, the 1999 nonradiological soil results do not show any noteworthy changes in the low levels of chemical residues on Duquesne Light and Valley National Gases properties.

TABLE 14

\begin{tabular}{|c|c|c|c|c|c|c|}
\hline \multicolumn{7}{|c|}{$\begin{array}{l}\text { DUQUESNE LIGHT and VALLEY NATIONAL GASES INC. SOIL } \\
\text { NONRADIOLOGICAL RESULTS(1) }\end{array}$} \\
\hline \multirow{2}{*}{$\begin{array}{l}\text { SAMPLE } \\
\text { LOCATION }\end{array}$} & \multicolumn{3}{|c|}{$\begin{array}{l}\text { VOCs }^{(2)} \\
\text { (mg/kg) }\end{array}$} & \multicolumn{2}{|c|}{$\begin{array}{l}\mathrm{PCBs}^{(2)} \\
(\mathrm{mg} / \mathrm{kg})\end{array}$} & \multirow{2}{*}{$\begin{array}{l}\begin{array}{c}\text { PAHs } \\
(\mathbf{m g}) \\
\text { B(a) }\end{array} \\
\text { (a) }\end{array}$} \\
\hline & PCE & TCE & $\overline{D C E}$ & 1254 & 1260 & \\
\hline \multicolumn{7}{|c|}{ Main Wet-weather Drainage Ditch } \\
\hline DL-01 & 0.028 & 0.008 & $<0.006$ & $<0.120$ & 8.2 & 4.0 \\
\hline WW-01 & 1.8 & $0.140 \mathrm{~J}^{(3)}$ & $<0.260$ & $<0.150$ & $2.3 \mathrm{~K}^{(3)}$ & $0.220 \mathrm{~J}$ \\
\hline WW-02 & 0.210 & $0.021 \mathrm{~J}$ & $<0.007$ & $<0.130$ & 4.0 & $0.870 \mathrm{~J}$ \\
\hline WW-03 & 0.011 & $<0.005$ & $<0.005$ & $<0.110$ & 0.420 & $0.093 \mathrm{~J}$ \\
\hline WW-04 & $<0.006$ & $<0.006$ & $<0.006$ & $<0.100$ & 0.120 & $0.130 \mathrm{~J}$ \\
\hline \multicolumn{7}{|c|}{ Secondary Wet-Weather Drainage Bitch ${ }^{3}$} \\
\hline DL-01 & $<0.010$ & $<0.010$ & $<0.010$ & $<0.020$ & 0.036 & $0.450 \mathrm{~J}$ \\
\hline DL-02 & $<0.009$ & $<0.009$ & $<0.009$ & $<0.017$ & 0.035 & $0.290 \mathrm{~J}$ \\
\hline DL-03 & $<0.008$ & $<0.008$ & $<0.008$ & $<0.016$ & $<0.016$ & $0.250 \mathrm{~J}$ \\
\hline DL-04 & $<0.008$ & $<0.008$ & $<0.008$ & $<0.020$ & 0.021 & $0.130 \mathrm{~J}$ \\
\hline DL-05 & $<0.010$ & $<0.010$ & $<0.010$ & $<0.022$ & $<0.022$ & $0.091 \mathrm{~J}$ \\
\hline DL-06 & $<0.008$ & $<0.008$ & $<0.008$ & $<0.018$ & $<0.018$ & $0.130 \mathrm{~J}$ \\
\hline
\end{tabular}

NOTES: (1) The results represent the maximum results where more than one sample was analyzed from a sample location.

(2) Samples were analyzed for 40 volatile organic compounds (VOCs), seven different polychlorinated biphenyl (PCB) isomers, and 17 polynuclear aromatic hydrocarbon (PAHs). Results are presented only for the potential contaminantsof-concern.

$P C E=$ Tetrachloroethylene; $T C E=$ Trichloroethylene; $D C E=1,2-$ Dichloroethylene; and $B(a) P=B e n z o$ (a) Pyrene.

(3) $\mathrm{J}=$ Analyte present. Reported value may not be accurate or precise.

$K=$ Analyte present. Reported value may be biased high.

(4) This ditch traverses a portion of Duquesne Light and Valley National Gases properties.

(5) This ditch is solely on Duquesne Light property.

The results of sediment sampling for chemical residues in the site's storm drain system and in the Bull Run Monitoring Station that receives the majority of the storm drain discharges are shown in Table 15. The sample locations are shown in Figure 4. The results show the presence of low levels of polychlorinated biphenyls (PCBs), volatile organic compounds (VOCs), and mercury in some of the samples of storm drain sediment. The PCB results in the storm drain sediment ranged from $<0.011$ to $73.9 \mathrm{mg} / \mathrm{kg}$. Tetrachloroethylene (PCE), the primary VOC of concern, was detected in only one sample at $0.006 \mathrm{mg} / \mathrm{kg}$ and mercury ranged from $<0.05$ to $7.51 \mathrm{mg} / \mathrm{kg}$. The mercury concentration in $\mathrm{MH} 10.2$ was well within the range of mercury concentrations $(0.23-9.1 \mathrm{mg} / \mathrm{kg})$ detected in the storm system sediment and reported during the RCRA Facility Investigation, Reference (1). Therefore, these results are consistent with previous data.

Low levels of PCE, to a maximum concentration of $0.030 \mathrm{mg} / \mathrm{kg}$ were found in samples from the Bull Run Stream. Traces $(0.07-0.10 \mathrm{mg} / \mathrm{kg})$ of a PCB compound were also detected in the Bull Run Stream samples. The sources of these chemicals are most likely the residual contamination in and 
around the storm drain lines as discussed in detail in Reference (1). These results are consistent with previous data.

TABLE 15

\begin{tabular}{||l|c|c|c|c|c|c||}
\hline \multicolumn{6}{|c|}{$\begin{array}{c}\text { SAMPLE } \\
\text { LOCATION }\end{array}$} & \multicolumn{5}{|c||}{$\begin{array}{c}\text { VOCs } \\
\text { (mg/kg) }\end{array}$} & \multicolumn{3}{c||}{$\begin{array}{c}\text { PCBs } \\
\text { (mg/kg) }\end{array}$} & \multirow{2}{*}{$\begin{array}{c}\text { Hg } \\
\text { (mg/kg) }\end{array}$} \\
\cline { 2 - 8 } & PCE & TCE & DCE & 1254 & 1260 & \\
\hline
\end{tabular}

NOTES: (1) The results represent the maximum result where more than one sample was analyzed for a sample location. Samples were analyzed for over 40 volatile organic compounds (VOCs) and seven different polychlorinated biphenyl (PCB) isomers. Results are presented only for the potential contaminants-of-concern. PCE = Tetrachloroethylene; TCE = Trichloroethylene; $\mathrm{DCE}=$ Trans 1,2-Dichloroethylene; and $\mathrm{Hg}=$ Mercury.

(2) $\mathrm{J}=$ Analyte Present. Reported value may not be accurate or precise.

(3) $\mathrm{NM}=$ Not Measured 


\section{E. RADIATION MONITORING}

The purpose of the environmental radiation monitoring program is to measure the ambient radiation levels around the Site to confirm that site operations have not altered the natural radiation background levels.

\section{Radiation Sources}

The sources of radiation at the Site include small specimens of irradiated and unirradiated fuel materials which were handled, processed, and stored at the Site. There are no nuclear reactors at the Site.

\section{Radiation Monitoring}

Environmental radiation levels were monitored in the vicinity of the Site with a network of lithium fluoride thermoluminescent dosimeters (TLDs). The approximate locations of the Site TLD monitors are shown on Figure 8. Control TLD monitors were posted at locations remote from the Site to measure the natural background radiation levels typical for western Pennsylvania. The control TLDs were located in nearby communities (Pleasant Hills, Reserve Township, Greensburg, Mt. Pleasant, Elizabeth, and Port Vue, PA). All TLD monitors were posted for quarterly exposure periods.

In addition to the TLD network, which was the primary monitoring method, a radiation survey was conducted around the site perimeter.

In 1999, a radiation survey was performed on Duquesne Light property that is adjacent to the Inactive Waste Site. The shaded area in Figure 6 shows the Duquesne Light property that was surveyed.

\section{Radiation Analyses}

The environmental TLDs were calibrated by a 25 millirem (mrem) exposure to a cesium-137 standard source. Only TLDs which exhibited a response within $\pm 10 \%$ of the mean response were selected for environmental radiation monitoring. The TLD radiation exposures were measured quarterly utilizing an automated TLD readout system which was calibrated prior to the processing of the TLDs. TLD results were corrected to assure that the environmental TLDs reflected only the exposure received during the time they were posted in the environment.

The perimeter radiation survey and the Duquesne Light property survey was conducted using a lowlevel radiation survey meter (PRM-7). This meter was calibrated with cesium-137 within six months prior to use and source checked for proper operation immediately prior to use.

\section{Radiation Monitoring Results and Conclusions}

The TLD results in Table 16 summarize the radiation levels measured during each quarter. The annual-average radiation exposure for the on-site TLDs was $78 \mathrm{mrem}$. The annual average radiation exposure at the off-site locations was 68 mrem. A statistical t-ratio test (Student- $t$ ) was used to evaluate the on-site and the off-site TLD radiation exposure. The results demonstrated that the exposure received by an individual located at the site perimeter was not different from that received from background radiation in the surrounding area.

The radiation dose rates measured during the perimeter radiation survey averaged approximately $0.009 \mathrm{mrem} / \mathrm{hr}$ which, integrated over the TLD exposure period in 1999, predicted an annual exposure of 79 mrem. 


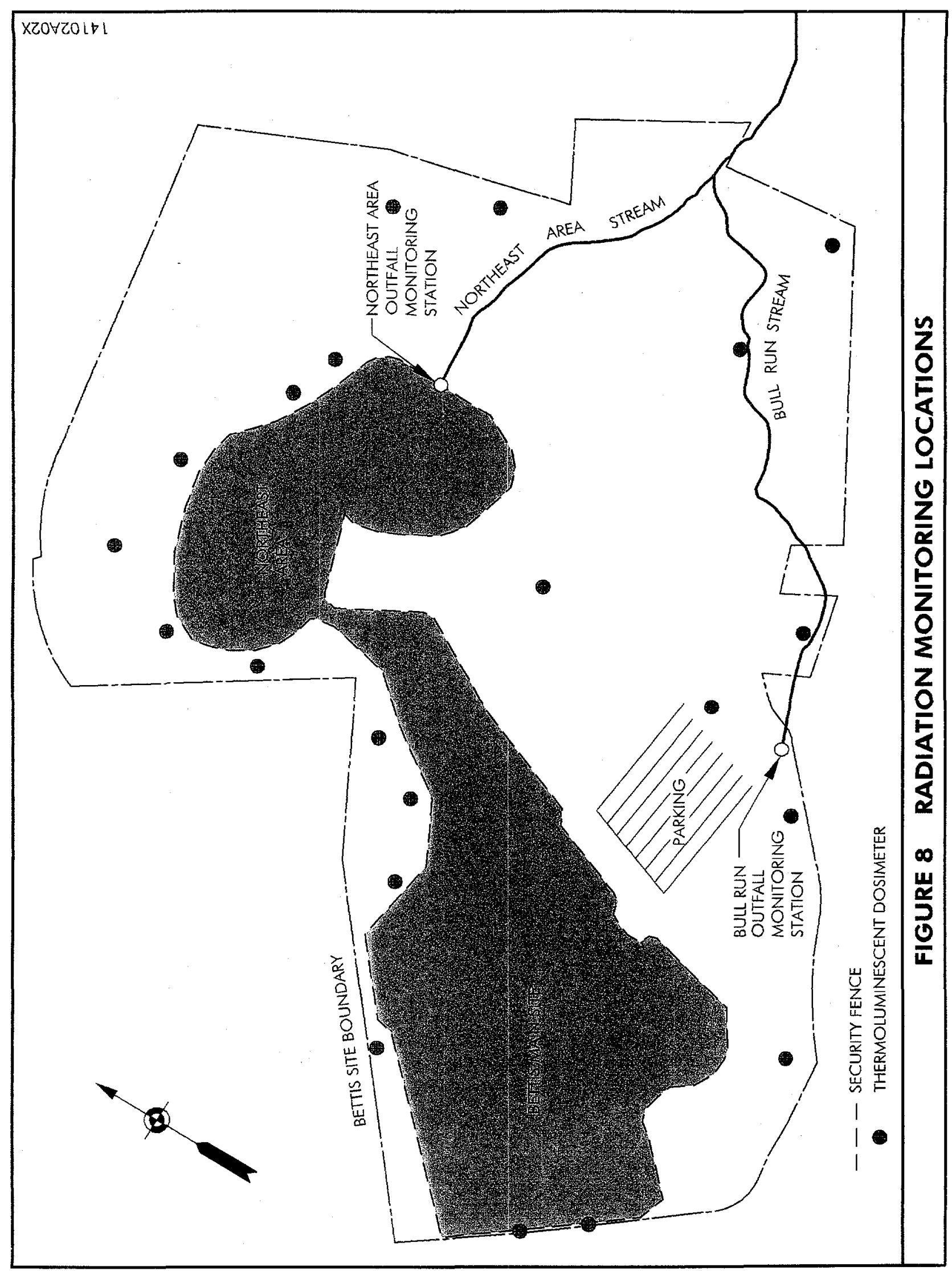


TABLE 16

\begin{tabular}{|c|c|c|c|c|c|c|}
\hline \multicolumn{7}{|c|}{ THERMOLUMINESCENT DOSIMETER (TLD) ENVIRONMENTAL RADIATION } \\
RESULTS \\
\hline $\begin{array}{c}\text { Quarterly } \\
\begin{array}{c}\text { Exposure } \\
\text { Period }\end{array}\end{array}$ & $\begin{array}{c}\text { ON-SITE RADIATION RESULTS } \\
\text { Number } \\
\text { of Meas. }\end{array}$ & $\begin{array}{c}\text { Range } \\
\text { (mrem) }\end{array}$ & $\begin{array}{c}\text { Average } \\
\text { (mrem) }\end{array}$ & $\begin{array}{c}\text { OFF-SITE BACKGROUND RESULTS } \\
\text { Of Meas. }\end{array}$ & $\begin{array}{c}\text { Range } \\
\text { (mrem) }\end{array}$ & $\begin{array}{c}\text { Average } \\
\text { (mrem) }\end{array}$ \\
\hline First & 21 & $16-27$ & 20.4 & 6 & $11-24$ & 17.8 \\
\hline Second & 21 & $15-26$ & 19.6 & 6 & $12-23$ & 17.5 \\
\hline Third & 21 & $15-28$ & 20.1 & 6 & $11-24$ & 17.0 \\
\hline Fourth & 20 & $13-23$ & 18.0 & 6 & $10-21$ & 16.2 \\
\hline
\end{tabular}

The 1999 radiation monitoring results were consistent with the range of natural radiation levels of 82 to $104 \mathrm{mrem} / y e a r$ observed in an U.S. Public Health Service survey of the northwest and southwest areas of Pennsylvania, Reference (9).

Also, the radiation monitoring results were consistent with the range of natural radiation levels of 79 to $105 \mathrm{mrem} /$ year determined by an aerial radiation survey, Reference (10), that encompassed a 100square-mile area around the Site. Therefore, it was concluded that the radiation exposure to the general public at the site perimeter was not above the exposure received from natural background radiation. The data show that site operations did not cause any measurable change in the natural radiation environment surrounding the Site.

Duquesne Light property, shown in Figure 6, was surveyed for radiation after the identification of a few small wet-weather drainage areas to the east of the main wet-weather ditch shown on Figure 6. (These areas were identified after Duquesne Light removed the dense vegetation along their power lines.) The new ditches represent potential pathways for migration of residual radioactivity and chemicals from the Inactive Waste Site to Duquesne Light property. Soil samples were collected from the largest of the newly discovered ditches and the samples were analyzed for select radiological and chemical residues. The analytical results were reported in the previous section of this report. The radiation survey results are consistent with the results of the radiological soil samples. The radiation readings ranged from 0.010 to $0.012 \mathrm{mrem} / \mathrm{hr}$. Any radiation exposure that could be incurred realistically from access to this remote area would be well below the radiation exposure limit specified in Reference (4) for individual members of the public. 


\section{CONTROL OF CHEMICAL AND HAZARDOUS WASTES}

\section{Origin}

Operations at the Site resulted in the generation of various types of chemical and hazardous wastes. These wastes included acid solutions, polychlorinated biphenyls, photographic solutions, oil solutions containing metals and organic solvents, batteries, and organic solvent contaminated solids.

\section{Control Program}

Hazardous wastes were managed in accordance with environmental regulations of the Commonwealth of Pennsylvania. Nonhazardous chemical wastes were managed in accordance with the Site's National Pollutant Discharge Elimination System Permit or other applicable Federal and State, or local regulations. The control programs minimized the quantity of waste generated, assured safe handling and storage of the wastes on-site, and provided for proper disposal of the wastes.

Specific training was provided to personnel who handled hazardous wastes to assure that they were knowledgeable of safe handling techniques and emergency response procedures. Chemical wastes were accumulated in designated staging and storage areas where they were segregated and packaged for shipment. Storage and accumulation areas were inspected periodically to verify that hazardous wastes were properly stored and controlled in accordance with approved procedures. Waste was stored only as necessary to accumulate sufficient volume for economical shipment to a waste disposal vendor.

The Environmental Protection Agency and the Pennsylvania Department of Environmental Protection conducted an on-site inspection of the hazardous waste management program in 1999. The Site was found to be in compliance. No violations or items of noncompliance were identified during this inspection.

\section{Disposal}

No chemical or hazardous wastes were disposed on the Site. Approximately 48,670 pounds of hazardous waste were shipped off-site to permitted facilities for final disposition. Written documentation was received from these facilities verifying that the waste was received and handled in accordance with requirements. The Site chose vendors with treatment and disposal methods that would reduce long-term concerns and threats to the environment. 


\section{CONTROL OF RADIOACTIVE WASTES}

\section{Origin}

Operations at the Site resulted in the generation of various types of low-level radioactive wastes. These wastes included liquids, filters, metal scrap, rags, resin, paper, soil, plastic, and decontamination debris.

\section{Control Program}

All radioactive wastes were managed in accordance with the DOE Naval Nuclear Propulsion Program radiological control requirements.

The volume of waste containing radioactivity was minimized through the use of detailed work procedures and worker training to limit the amount of material that contacted radioactivity during work on radioactive systems and components; waste compaction was also used.

Detailed procedures were used during generation, handling, packaging, and transportation of radioactive waste material. Radioactive wastes shipped off-site were packaged in accordance with applicable DOE disposal site criteria and the U. S. Department of Transportation regulations in Reference (11). In addition, all radioactive liquid wastes were solidified prior to shipment. Internal reviews were made prior to each shipment to ensure that the radioactive material was properly identified, surveyed, and packaged in accordance with Federal and disposal site requirements.

\section{Disposal/Treatment/Recycling}

Radioactive waste was shipped off-site for disposal. During 1999, approximately 278 cubic meters of radioactive waste, which contained a total of 2.06 Curies of radioactivity, were shipped from the Bettis Site. As a waste minimization technique, 39 cubic meters of radioactive surface contaminated scrap metals were shipped off-site to a commercial radioactive material processing facility for radioactive metal recycling. The total amount of radioactive material shipped off-site for disposal or recycling is less than $1 \%$ of the volume of low-level radioactive waste typically dispositioned annually by all DOEowned facilities. 


\section{CONTROL OF MIXED WASTES}

\section{Origin}

A mixed waste is a waste that is both RCRA hazardous and radioactive. Operations at the Site resulted in the generation of a very small quantity of mixed wastes. These wastes included acidic solutions, chromate solutions, oils, soil, and debris.

\section{Control Program}

The Naval Nuclear Propulsion Program has agreed to apply Pennsylvania hazardous waste requirements to the hazardous constituents in mixed waste prior to Pennsylvania being authorized by the EPA to regulate mixed waste. All mixed wastes were managed in accordance with the Bettis Mixed Waste Management Plan which was concurred with by the Pennsylvania Department of Environmental Protection. In addition, the DOE and the EPA signed a Consent Agreement and Consent Order for the management and treatment of mixed waste.

Since mixed wastes are RCRA hazardous and radioactive, the controls for hazardous wastes were applied to the hazardous constituents and the controls for radioactive wastes were applied to the radioactive constituents.

In September 1999, the Pennsylvania Department of Environmental Protection and the EPA conducted a mixed waste management inspection at Bettis. No deficiencies were noted.

\section{Disposal}

Mixed wastes were not disposed on-site. Mixed wastes were stored on-site pending treatment and disposal facility availability as specified in the Site Treatment Plan, which is implemented by the Consent Agreement and Consent Order.

In 1999, three shipments of mixed waste totaling 1.8 cubic meters were made from Bettis-Pittsburgh. In March 1999, 0.002 cubic meters of mixed waste consisting of oil was shipped to the Savannah River Site Consolidated Incineration Facility for treatment. In December 1999, 1.6 cubic meters of mixed waste consisting of inorganic sludges and particulates was shipped to Waste Control Specialists for treatment and disposal. Also in December 1999, 0.2 cubic meters of mixed waste consisting of organic waste was shipped to the Idaho National Environmental and Engineering Laboratory Waste Experimental Reduction Facility for treatment. 


\section{ENVIRONMENTAL MONITORING QUALITY ASSURANCE}

\section{General Quality Assurance Controls}

All environmental monitoring was conducted by trained and qualified personnel. Samples were collected in strict accordance with written procedures, and sample containers were specifically selected and cleaned for each type of sample in accordance with Federal guidelines. Samples were preserved upon collection, where necessary, and handled using a chain-of-custody procedure to preserve the integrity of the samples from the point of collection through analysis. Analyses were performed in accordance with approved procedures that met Federal guidelines and requirements.

\section{Radiological Quality Assurance Controls}

Analyses for radioactivity were performed by Bettis. The internal quality control followed the guidelines and practices recommended by the Nuclear Regulatory Commission in Reference (12) and the EPA in Reference (13). Bettis participated in an interlaboratory quality assurance crosscheck program sponsored by the DOE (Environmental Measurements Laboratory). This agency transmitted samples of water, air filters, vegetation, and soil to Bettis for radiological analyses. The purpose of this program was to evaluate the precision and accuracy of the Site's radioanalytical techniques and results. Appendix A summarizes the results from the crosscheck program. The Site's results demonstrated satisfactory performance in the interlaboratory quality assurance program.

\section{Nonradiological Quality Assurance Controls}

Nonradiological analyses were normally performed by off-site laboratories under contract to Bettis. These laboratories followed quality control guidelines recommended by the EPA in References (2) and (3) as appropriate. Quality control samples such as reagent blanks, field blanks, duplicates, replicates, and/or reference standards were used to monitor sampling and analytical laboratory performance, and measure accuracy and precision. In addition, an audit of an off-site laboratory was conducted by Bettis Analytical Chemistry and Environmental Engineering personnel to ensure the laboratory practices were adequate and in accordance with approved procedures.

Selected data packages from these off-site laboratories were reviewed by chemists in the Bettis Analytical Chemistry group using guidelines established by EPA Region III or by an independent subcontracted data validator. These reviews included a check of calculations, standards, graphs, and laboratory quality control sample results (blanks, spikes, reference standards). Concerns noted in the reviews were resolved with the laboratories before final acceptance of the data. In some cases (i.e., Tables $9 \mathrm{~A}$ and $9 \mathrm{~B}$ ), the validity of the data was qualified. Overall, the analytical laboratories demonstrated satisfactory performance. 


\section{ASSESSMENT OF RISK FROM CHEMICAL RESIDUES}

A risk assessment was prepared as part of the Site's RCRA Facility Investigation. This assessment was prepared using the Superfund related methodology outlined in Reference (14). The detailed assessment, presented in Reference (1), is summarized below.

The objective of the assessment was to determine the reasonable maximum exposure of on-site and off-site populations to environmental contamination at the Site. The media containing chemical residues are soil, ground water, surface water (springs and streams), and sediment. Residues whose concentrations exceeded the EPA Region III's risk-based screening levels were selected as potential contaminants-of-concern. The residues evaluated were largely volatile organic compounds, polychlorinated biphenyls, and polynuclear aromatic hydrocarbons.

Risks were evaluated for realistic industrial land-use scenarios, now and in the future. EPA exposure parameters were used for off-site commercial/industrial workers at Duquesne Light (DL) and Valley National Gases Incorporated (VNGI). Site-specific exposure parameters were used for pathways where standard EPA values were not available or were not appropriate. All exposure pathways judged to be complete now and in the future were quantified. Ground water exposure was not quantified because Bettis-Pittsburgh and off-site populations receive municipal water and this is unlikely to change in the foreseeable future.

The risk assessment quantified carcinogenic risk and noncarcinogenic hazard for four potentially exposed populations:

- On-site construction workers exposed to chemical residues in soil;

- Off-site commercial/industrial workers exposed to chemical residues in soil;

- Trespassing children exposed to chemical residues in water and sediment in springs and streams; and

- Off-site children exposed to chemical residues in water in a spring and sediment in a stream.

Based on EPA criteria, the calculated carcinogenic risk and noncarcinogenic hazard values were compared with the values of $0.000001\left(1 \times 10^{-6}\right)$ and 1.0 , respectively, which represent acceptable risk levels.

For on-site construction workers engaged in excavation activities, carcinogenic risks were quantified for all on-site locations where potential contaminants-of-concern were present. The noncarcinogenic hazard could be calculated only for two sites and the values were several orders of magnitude below the comparison criterion of 1.0. The estimated carcinogenic risks did not exceed the comparison criterion of $1 \times 10^{-6}$ at any location, with the highest being $5.4 \times 10^{-7}$ for soil in the Inactive Waste Site (Figure 6).

For off-site workers on DL and VNGI properties below the Inactive Waste Site (IWS), the estimated carcinogenic risk from exposure to polychlorinated biphenyls and polynuclear aromatic hydrocarbon compounds in surface soil in the main drainage ditch below the Inactive Waste Site (Figure 6) is about $2 \times 10^{-5}$. This risk estimate is highly conservative due to the assumptions used in calculating intake 
(i.e., exposure for 250 days/year for 25 years) and because the chemical residues in this area are remote from DL and VNGI work areas. Actual carcinogenic risk would be much lower.

Exposure to surface water and sediment in the on-site and off-site streams and springs was quantified for children, the only group that might have more than occasional contact with these media. The highest estimated risk was $1.0 \times 10^{-7}$ for exposure to Thompson Run Stream sediment, which is below the comparison criterion of $1 \times 10^{-6}$. Noncarcinogenic hazards were several orders of magnitude below the comparison criterion of 1.0 .

In summary, chemical residues in the environment at the Site do not pose significant health risks to potentially exposed populations using reasonable maximum exposure assumptions. The only study area with a carcinogenic risk estimate exceeding the comparison criterion is the drainage ditch area on DL and VNGI properties, with a maximum carcinogenic risk of about $2 \times 10^{-5}$. However, exposure (skin contact, ingestion, and inhalation) for $\mathbf{2 5 0}$ days/year for 25 years is required to achieve this risk. This risk is highly conservative because the contaminated area is in infrequently accessed or undeveloped locations. In reality, the risk to VNGI or DL workers is far less than $1 \times 10^{-6}$. Noncarcinogenic risks were all significantly less than the comparison criterion of 1.0.

The 1999 results of analyses for chemical residues in the environment support the conclusions of the risk assessment. 


\section{CORRECTIVE MEASURES STUDY}

After approving the Final RCRA Facility Investigation Report, Reference (1), the EPA approved the Final Corrective Measures Study Report, Reference (15). The purpose of the study was to evaluate and recommend, where needed, corrective measures that would protect human health and the environment. The need for corrective measures was judged primarily from the carcinogenic risks and the noncarcinogenic hazards potentially posed by the chemical contaminants-of-concern at the Site. The risk assessment, discussed in the previous section, demonstrated that the chemical residues in the environment at the Site do not realistically present a significant carcinogenic risk or noncarcinogenic hazard to human health. Therefore, extensive corrective measures are not necessary to protect human health now or in the foreseeable future.

The actions below were proposed to the EPA to ensure the conclusions of the Final RFI Report remain accurate in the future, to limit potential migration of chemical residues, and to reduce the chemical residues in the environment to as-low-as-reasonably-achievable. The EPA approved these actions in March 1995.

- Intercept four springs and known seepage which drain to the Bull Run and Northeast Area Streams, treat the water to reduce the volatile organic compounds, and add the point discharge to the Site's National Pollutant Discharge Elimination System Permit.

- Remove sediment containing low levels of polychlorinated biphenyls from four storm drain manholes.

- Remove the only section of the coke gas lines known to be breached. Remove sludge and water from behind the downgrade ends of both lines.

- Monitor the ground water, the receiving stream water, and the storm drain outfall sediments for the chemical contaminants-of-concern on an annual basis. Evaluate the need for continuation of these monitoring programs after five years.

- Monitor the seepage from the Inactive Waste Site and sediment in the wet-weather drainage ditch, both of which are on Duquesne Light and Valley National Gases properties, on an annual basis. Evaluate the need for continuation of this monitoring program after five years.

- Monitor the interior of the coke gas lines annually at the four existing portals for changes in contents that could indicate a loss of integrity in the lines.

- Maintain existing policies and procedures which ensure worker safety and health for excavation activities and proper disposal of environmental media containing chemical residues.

- Maintain existing access controls to various areas containing chemical residues.

The EPA issued its preliminary corrective measure recommendations for public comment in September 1995 in their Statement of Basis document. The EPA's recommendations encompassed all of the Site's proposed corrective measures and included several additional corrective measures. The EPA responded to public comments and issued the final corrective measures in its Final Decision and Response to Comments document in October 1997. The final corrective measures were essentially unchanged from those in the Statement of Basis document. The next action is for the EPA 
to issue a Corrective Measures Implementation Order to govern the implementation of the selected corrective measures. In the interim, the Site is voluntarily implementing the corrective measures proposed in the Site's Corrective Measures Study Report.

One of the voluntary corrective measures implemented on-site was the installation of the Springwater Intercept System (SIS). During 1999, a Consent Order and Agreement (COA) for operation of the SIS was signed between the DOE Pittsburgh Naval Reactors Office and the Pennsylvania Department of Environmental Protection (PADEP). This COA lifted a Notice of Violation issued to Bettis by the PADEP for releases to the environment. 


\section{ASSESSMENT OF RADIATION DOSE-TO-MAN}

Effluent monitoring results at the Site during 1999 demonstrated that radioactivity releases were below applicable Federal radioactivity limits. Radiation exposure to the general public from airborne releases was too low to measure and could only be determined with calculational models using the airborne effluent radioactivity data. Airborne effluent radioactivity data which were below the minimum detection levels were assumed to be at the minimum detection level. Therefore, a conservative assessment of the radiation dose-to-man was performed by analyzing the exposure pathways whereby radioactivity might be transmitted from the Site to the general public. The following potential exposure pathways were considered in this assessment. The first two pathways contribute more than $99 \%$ of the dose-to-man.

- Direct radiation from residual radioactivity in the Bull Run Stream basin;

- Inhalation of airborne radioactivity;

- Exposure to ground deposits from airborne radioactivity;

- Immersion in the atmosphere containing the released airborne radioactivity;

- Ingestion of food contaminated by deposition of airborne radioactivity;

- Ingestion of radioactivity in the drinking water supply; and

- Direct radiation from Site operations.

Radioactivity attributed to Bettis operations was not released to the Site's streams in 1999. Therefore, exposure to radioactivity in water was not a potential exposure pathway. Specific radionuclide composition of the airborne releases was factored into the assessment. The dose for each exposure pathway was explicitly calculated for each radionuclide and applicable daughters. The air pathway calculations used wind direction data and meteorological parameters that were measured by the Site's meteorological monitoring system in 1999. The Site's meteorological monitoring system measures wind speed, gusts, wind direction, temperature, relative humidity, and inches of rain. The measurements are integrated over 15-minute intervals. The system is part of the Atmospheric Release Advisory Capability service developed by Lawrence Livermore National Laboratory to model the atmospheric release of radioactive materials. The population distribution in the vicinity of the Site was based on 1990 census data. The atmospheric dispersion of the Site's radioactive airborne releases and resulting dose were calculated using an EPA-approved computer program described in Reference (16). The radiation dose assessment attributed to Site operations during 1999 is presented in Table 17. Radiation doses were calculated for the whole body and most limiting organ of individuals at locations of maximum exposure to the nearest offsite receptor and for the total population within 50 miles of the Site. 
TABLE 17

\begin{tabular}{|c|c|c|}
\hline \multirow{2}{*}{\multicolumn{3}{|c|}{$\begin{array}{l}\text { RADIATION DOSE-TO-MAN FROM SITE OPERATIONS } \\
\text { Maximum Estimated Radiation Exposure to the Nearest Off-Site Receptor }\end{array}$}} \\
\hline & & \\
\hline Exposure Pathways & $\begin{array}{c}\text { Effective } \\
\text { Whole Body Dose } \\
\text { (mrem) }\end{array}$ & $\begin{array}{l}\text { Maximum Dose to } \\
\text { Limiting Organ } \\
\text { (mrem) }\end{array}$ \\
\hline $\begin{array}{l}\text { - Liquid Pathways } \\
\text { Airborne Pathways } \\
\text { o Particulate Radioactivity } \\
\text { Release }^{(3)} \\
\text { - Gaseous Radioactivity Release }{ }^{(4)} \\
\text { - EPA Limit } \\
\text { - Direct Exposure Pathways } \\
\text { o Direct Radiation from } \\
\text { Bettis Operations } \\
\text { - Exposure to Residual } \\
\text { Radioactivity in the Bull Run } \\
\text { Basin }\end{array}$ & $\begin{array}{c}\text { None } e^{(2)} \\
0.00035 \\
0.28 \\
10 \\
\text { None } \\
0-2.3\end{array}$ & $\begin{array}{c}\text { None }^{(2)} \\
0.007 \text { (Bone) } \\
2.05 \text { (Bone) }\end{array}$ \\
\hline $\begin{array}{l}\text { Maximum Whole Body Dose to Individual } \\
\text { o DOE Limit }\end{array}$ & $\begin{array}{l}0.28-2.6 \\
100\end{array}$ & \\
\hline \multicolumn{3}{|c|}{ 50-Mile Population Radiation Exposure } \\
\hline Exposure Pathways & $\begin{array}{c}\text { Estimated Popul } \\
\text { Effective } \\
\begin{array}{c}\text { Whole Body Dose } \\
\text { (man-rem) }\end{array}\end{array}$ & $\begin{array}{c}\text { Dose Equivalent }{ }^{\prime \prime} \\
\text { Maximum Dose to } \\
\text { Limiting Organ } \\
\text { (man-rem) }\end{array}$ \\
\hline $\begin{array}{l}\text { Liquid Pathways } \\
\text { - Airborne Pathways } \\
\text { - Direct Exposure Pathways }\end{array}$ & $\begin{array}{c}\text { None } e^{(2)} \\
1.45 \\
0-0.01 \\
\end{array}$ & $\begin{array}{c}\text { None }^{(2)} \\
10.6 \text { (Bone) } \\
0-0.01 \text { (Whole Body) } \\
\end{array}$ \\
\hline Maximum Whole Body Population Dose & 1.46 & \\
\hline
\end{tabular}

NOTES: (1) The dose estimated for the airborne pathways is the committed "50-year" effective dose equivalent. This means that an individual would receive the indicated dose over a 50-year period following inhalation of radioactivity released in this calendar year.

(2) The Site did not discharge any radioactivity into the liquid effluent streams.

(3) The principal contributors to the calculated dose from particulate radioactivity releases were conservatively assumed to be cobalt-60 and thorium-232.

(4) The contributors to the gaseous radioactivity releases were radon-220 and its daughters.

The results in Table 17 show that the maximum whole body radiation exposure which any member of the public could hypothetically receive due to past and present operations ranged from 0.28 to 2.6 mrem. Nearly all of this very low potential dose would be from gaseous radioactivity and from exposure to the Bull Run soil and sediments that contain residual radioactivity from operations over 30 years ago. Based on a conservative estimate that an individual would spend as much as one hour per day, every day of the year, walking along the Bull Run stream bank in the areas with radiation levels above background, the annual hypothetical dose received would be approximately $2.3 \mathrm{mrem}$. This is less than the amount of additional radiation exposure an individual would receive from a cross-country airplane flight, Reference (17). The maximum potential radiation dose is well below the most 
restrictive dose limits of the Nuclear Regulatory Commission and the DOE. The maximum potential dose is less than $1 \%$ of the approximately 300 mrem dose a person receives each year from naturally occurring radiation in the environment, Reference (18). The dose resulting from the low levels of radioactivity in the Site's airborne effluents is significantly less than the limits of the EPA in Reference (7).

In conclusion, the maximum radiation exposure to any member of the public as a result of operations at the Bettis Site during 1999 was substantially below the radiation exposure limits established by the DOE, the Nuclear Regulatory Commission, and the EPA. Moreover, the accumulated radiation exposure received during 1999 by the total population of approximately 3,000,000 within 50 miles of the Site was conservatively estimated to be approximately 1.46 man-rem, which is negligible compared to the approximately 900,000 man-rem dose received from natural background radiation. Therefore, the radioactivity released from the Site, as a result of past and present operations, has not resulted in any significant radiation exposure to the general public. 


\section{ENVIRONMENTAL PERMITS}

The Site has obtained or applied for the environmental permits required by applicable regulations. Table 18 provides a listing of the environmental permits for the Bettis-Pittsburgh Site in 1999.

TABLE 18

\begin{tabular}{|c|c|c|c|c|}
\hline \multicolumn{5}{|c|}{ ENVIRONMENTAL PERMITS } \\
\hline $\begin{array}{l}\text { Operation } \\
\text { Permitted }\end{array}$ & Unit Permitted & Permit Number & $\begin{array}{l}\text { Permitting } \\
\text { Agency }\end{array}$ & Renewal Date \\
\hline \multirow{4}{*}{$\begin{array}{c}\text { Air } \\
\text { Emissions }\end{array}$} & Bettis-Pittsburgh Site & $\begin{array}{l}\text { Operating Permit } \\
\text { Application } \\
95-0067\end{array}$ & $\begin{array}{l}\text { Allegheny County } \\
\text { Health Department }\end{array}$ & (Note 1) \\
\hline & Bettis-Pittsburgh Site & $\begin{array}{c}\text { Open Burning Permit } \\
\text { \#F99-15 }\end{array}$ & $\begin{array}{l}\text { Allegheny County } \\
\text { Health Department }\end{array}$ & December 31, 1999 \\
\hline & $\begin{array}{l}\text { Bettis-Pittsburgh Site } \\
\text { Asbestos Abatement } \\
\text { Operation \& } \\
\text { Maintenance Plan }\end{array}$ & PAA-99OM01 & $\begin{array}{l}\text { Allegheny County } \\
\text { Health Department }\end{array}$ & $\begin{array}{c}\text { December 31, } 1999 \\
\text { (Note 2) }\end{array}$ \\
\hline & $\begin{array}{l}\text { Asbestos Abatement, } \\
\text { Various Areas }\end{array}$ & $\begin{array}{c}\text { PAA 98-0261,0279, } \\
\text { PAA 99-0003, 0036, } \\
0154,0155,0232,0342 \\
0728,0874\end{array}$ & $\begin{array}{l}\text { Allegheny County } \\
\text { Health Department }\end{array}$ & (Note 3) \\
\hline \multirow{2}{*}{$\begin{array}{c}\text { Water } \\
\text { Discharges }\end{array}$} & $\begin{array}{l}\text { Bull Run } \\
\text { Monitoring Station, } \\
\text { Northeast Area } \\
\text { Monitoring Station, } \\
\text { Stormwater } \\
\text { Outfalls }\end{array}$ & $\begin{array}{l}\text { National Pollutant } \\
\text { Discharge Elimination } \\
\text { System Permit } \\
\text { PA0000914 }\end{array}$ & $\begin{array}{l}\text { Pennsylvania } \\
\text { Department of } \\
\text { Environmental } \\
\text { Protection }\end{array}$ & August 16, 2001 \\
\hline & $\begin{array}{l}\text { Springwater Intercept } \\
\text { System }\end{array}$ & $\begin{array}{c}\text { National Pollutant } \\
\text { Discharge Elimination } \\
\text { System Permit } \\
\text { Amendment } \\
\text { PA0000914-A2 }\end{array}$ & $\begin{array}{l}\text { Pennsylvania } \\
\text { Department of } \\
\text { Environmental } \\
\text { Protection }\end{array}$ & $\begin{array}{l}\text { August 16, } 2001 \\
\text { (Note 4) }\end{array}$ \\
\hline $\begin{array}{c}\text { Hazardous } \\
\text { and Mixed } \\
\text { Waste } \\
\text { Storage }\end{array}$ & $\begin{array}{l}\text { Chemical } \\
\text { Hazardous Waste } \\
\text { Storage Building } \\
\text { Mixed Waste Storage } \\
\text { Facility }\end{array}$ & $\begin{array}{c}\text { Hazardous Waste } \\
\text { Storage Permit } \\
\text { PA0890090004 }\end{array}$ & $\begin{array}{l}\text { Pennsylvania } \\
\text { Department of } \\
\text { Environmental } \\
\text { Protection }\end{array}$ & $\begin{array}{l}\text { February 23, } 2005 \\
\text { (Note 5) }\end{array}$ \\
\hline
\end{tabular}

NOTES: (1) A Site "Air Operating Permit" application was submitted to the Allegheny County Health Department in November 1995. The renewal date will be five years after the issuance date.

(2) Permit is renewed annually.

(3) Permits are required for asbestos abatement work. The individual work effort involves the removal or encapsulation of greater than 260 linear feet or 160 square feet of asbestos containing material. Permits are obtained on an as needed basis. Ten permits were active in 1999. Eight of the 10 active asbestos abatement permits were obtained in 1999.

(4) A NPDES permit amendment was issued on February 9, 1999 to allow for increased capacity of the Springwater intercept System.

(5) A revised "Part B" permit application was submitted to the Pennsylvania Department of Environmental Protection for operating the Mixed Waste Storage Facility on January 5, 1996. On December 1, 1999, DEP issued the revised permit.

As noted in previous sections, the inspections conducted by outside regulatory agencies found the Site to be in compliance with the requirements of the environmental permits discussed in Table 18. 
This page intentionally left blank 


\section{REFERENCES}

(1) Final RCRA Facility Investigation Report for the Bettis Laboratory, West Mifflin, Pennsylvania. June 1994.

(2) U.S. Environmental Protection Agency. "Guidelines Establishing Test Procedures for the Analysis of Pollutants." Code of Federal Regulations. Title 40, Part 136.

(3) U.S. Environmental Protection Agency. Test Methods for Evaluating Solid Waste Physical/Chemical Methods. SW-846.

(4) Nuclear Regulatory Commission. "Standards for Protection Against Radiation." Code of Federal Regulations. Title 10, Part 20.

(5) Commonwealth of Pennsylvania. "Chapter 93, Water Quality Standards." "Chapter 16, Water Quality Toxics Management Strategy." Pennsylvania Code. Title 25, Environmental Protection.

(6) U.S. Environmental Protection Agency. "National Primary Drinking Water Regulations". Code of Federal Regulations. Title 40, Part 141.

(7) U.S. Environmental Protection Agency. "National Emission Standards for Hazardous Air Pollutants; Subpart H - National Emission Standard for Radionuclide Emissions from Department of Energy Facilities." Code of Federal Regulations. Title 40, Part 61.

(8) Allegheny County Health Department Rules and Regulations, Article XXI, Air Pollution Control. November 1998.

(9) "Summary of Natural Environmental Gamma Radiation Using a Calibrated Portable Scintillation Counter." Radiological Health Data and Reports. Volume 9, Number 11, pp. 620-695. November 1968.

(10) "An Aerial Radiological Survey of West Mifflin, Pennsylvania, and Surrounding Areas." EG\&G/EM Sunvey Report. DOE/NR-8319. March 1984.

(11) U.S. Department of Transportation. "Hazardous Material Regulations." Code of Federal Regulations. Title 49, Parts 171-178.

(12) Nuclear Regulatory Commission. Regulatory Guide 4.15. February 1979.

(13) U.S. Environmental Protection Agency. Handbook for Analytical Quality Control in Radioanalytical Laboratories. EPA-600/17-77-008. August 1977.

(14) U.S. Environmental Protection Agency. Risk Assessment Guidance for Superfund (RAGS) Volume I (Part A), Human Health Evaluation Manual. 1989.

(15) Final Corrective Measures Study Report for the Bettis Laboratory, West Mifflin, Pennsylvania. January 1995. 


\section{REFERENCES (Continued)}

(16) U.S. Environmental Protection Agency. The Clean Air Act Assessment Package - 1988 (CAP-88) - A Dose and Risk Assessment Methodology for Radionuclide Emissions to Air. CAP88-PC, Version 1.0. March 1992.

(17) National Council on Radiation Protection and Measurements. "Exposure of the Population in the United States and Canada from Natural Background Radiation." NCRP Reports. Report No. 94. December 1987.

(18) International Commission on Radiological Protection. "Report of the Task Group on Reference Man." Annals of the ICRP. Publication 23. Pergamon Press. 1974. 


\section{DISTRIBUTION}

No. Copies

Admiral F. L. Bowman, Deputy Administrator

Naval Reactors

U. S. Department of Energy

Washington, D. C. 20585

Mr. H. A. Cardinali, Manager

Pittsburgh Naval Reactors Office, U.S. Department of Energy

Post Office Box 109

West Mifflin, Pennsylvania 15122

Office of Environmental Guidance and Compliance, EH-23

U. S. Department of Energy

Washington, D.C. 20585

U.S. Department of Energy

Headquarters Energy Library

1000 Independence Ave. SW

Room GA 138 - MA - 224

Washington, D.C. 20585

U.S. Department of Energy

Office of Scientific and Technical Information

Post Office Box 62

Oak Ridge, Tennessee 37831

Science and Technology Department

Carnegie Library of Pittsburgh

4400 Forbes Avenue

Pittsburgh, Pennsylvania 15213

Mr. Bradley M. Campbell, Regional Administrator

U. S. Environmental Protection Agency

Region III

1650 Arch Street

Philadelphia, Pennsylvania 19103-2029

Ms. Maria Parisi-Vickers, Deputy Director

Waste and Chemicals Management Division

U. S. Environmental Protection Agency

Region III

1650 Arch Street - 3WC00

Philadelphia, Pennsylvania 19103-2029 


\section{DISTRIBUTION (Continued)}

Mr. Paul Gotthold, Chief of Pennsylvania Operations

No. Copies

U. S. Environmental Protection Agency

Region III

1650 Arch Street - 3WC22

Philadelphia, Pennsylvania 19103-2029

Ms. Carol Amend, Environmental Services Division

U. S. Environmental Protection Agency

Region III

1650 Arch Street - 3ES30

Philadelphia, Pennsylvania 19103-2029

Robert Kramer, Branch Chief,

Energy, Radiation and Indoor Environment Branch

U. S. Environmental Protection Agency

Region III

1650 Arch Street - 3AP23

Philadelphia, Pennsylvania 19103-2029

The Honorable Arlen Specter

711 Hart Senate Office Bldg.

Washington, D.C. 20510

The Honorable Rick Santorum

120 Russell Bldg.

Washington, D. C. 20510

The Honorable Mike Doyle

U. S. House of Representatives

133 Cannon H.O.B.

Washington, D. C. 20515

Secretary James M. Seif

Department of Environmental Protection

Commonwealth of Pennsylvania

Rachel Carson State Office Building

Post Office Box 2063

Harrisburg, Pennsylvania 17105 - 2063

D. Richard Shipman, Division Chief

Division of Hazardous Waste Management

Bureau of Land Recycling and Waste Management

Department of Environmental Protection

Rachel Carson State Office Building

Commonwealth of Pennsylvania

Post Office Box 8471

Harrisburg, Pennsylvania 17105 


\section{DISTRIBUTION (Continued)}

Mr. Joseph W. Chnupa, Assistant Regional Director

No. Copies

Southwest Regional Office

Department of Environmental Protection

Commonwealth of Pennsylvania

400 Waterfront Drive

Pittsburgh, Pennsylvania 15222-4745

Mr. Terry A. Pallas, Chief, Monitoring and Compliance

Operations Section

Water Management Program

Department of Environmental Protection

Commonwealth of Pennsylvania

400 Waterfront Drive

Pittsburgh, Pennsylvania 15222-4745

Mr. James Yusko, Regional Manager

Radiation Protection Program

Department of Environmental Protection

Commonwealth of Pennsylvania

400 Waterfront Drive

Pittsburgh, Pennsylvania 15222-4745

David J. Allard, Director

Bureau of Radiation Protection

Department of Environmental Protection

Commonwealth of Pennsylvania

Rachael Carson State Office Building

P. O. Box 8469

Harrisburg, Pennsylvania 17105-8469

The Honorable Albert V. Belan

Pennsylvania Senate

Capitol Building

Harrisburg, Pennsylvania 17120

The Honorable Kenneth Ruffing

State Representative $-38^{\text {th }}$ District

751 Pittsburgh/McKeesport Blvd.

Dravosburg, Pennsylvania 15034

Bruce W. Dixon, M. D., Director

Allegheny County Health Department 3333 Forbes Avenue

Pittsburgh, Pennsylvania 15213 


\section{DISTRIBUTION (Continued)}

Mr. Roger Westman, Manager

No. Copies

Air Quality Program

Allegheny County Health Department

301 Thirty-ninth Street, Building \#7

Pittsburgh, Pennsylvania 15201-1891

Mr. Howard Bednar, Borough Manager

West Mifflin Borough

3000 Lebanon Church Road

West Mifflin, Pennsylvania 15122

The Honorable John Powell, Mayor

Borough of Dravosburg

226 Maple Avenue

Dravosburg, Pennsylvania 15034 
APPENDIX A

\begin{tabular}{|c|c|c|c|c|c|}
\hline \multicolumn{6}{|c|}{ USDOEIEML RADIOANALYTICAL QUALITY ASSURANCE RESULTS } \\
\hline Date & Media & Parameter & $\begin{array}{l}\text { Known } \\
\text { Value }^{(1)}\end{array}$ & $\begin{array}{l}\text { Reported } \\
\text { Value }^{(1)(2)}\end{array}$ & Evaluation $^{(3)}$ \\
\hline Mar99 & Water & $\begin{array}{c}\text { Cobalt-60 } \\
\text { Strontium-90 } \\
\text { Cesium-137 } \\
\text { Plutonium-238 } \\
\text { Plutonium-239 } \\
\text { Uranium-234 } \\
\text { Uranium-238 }\end{array}$ & $\begin{array}{c}1379.7 \\
110.808 \\
1063.125 \\
20.833 \\
27.25 \\
7.25 \\
7.07\end{array}$ & $\begin{array}{c}1458 \\
93.96 \\
1120.5 \\
14.607 \\
17.442 \\
7.155 \\
7.695\end{array}$ & $\begin{array}{c}\text { Acceptable } \\
\text { Acceptable with Warning } \\
\text { Acceptable } \\
\text { Not Acceptable(4) } \\
\text { Not Acceptable(4) } \\
\text { Acceptable } \\
\text { Acceptable }\end{array}$ \\
\hline Mar99 & Soil & Cesium-137 & 17806.5 & 18144 & Acceptable \\
\hline Mar99 & Vegetation & $\begin{array}{c}\text { Cesium-137 } \\
\text { Cobalt-60 }\end{array}$ & $\begin{array}{l}12609 \\
579.15\end{array}$ & $\begin{array}{c}13473 \\
648\end{array}$ & $\begin{array}{l}\text { Acceptable } \\
\text { Acceptable }\end{array}$ \\
\hline Mar99 & Air Filter & $\begin{array}{c}\text { Cobalt-57 } \\
\text { Cobalt-60 } \\
\text { Strontium-90 } \\
\text { Antimony-125 } \\
\text { Cesium-137 } \\
\text { Plutonium-238 } \\
\text { Plutonium-239 } \\
\text { Uranium-234 } \\
\text { Uranium-238 } \\
\end{array}$ & $\begin{array}{c}81.27 \\
133.92 \\
17.388 \\
96.93 \\
163.35 \\
7.3494 \\
3.3561 \\
1.619 \\
1.653 \\
\end{array}$ & $\begin{array}{c}79.11 \\
136.89 \\
14.04 \\
116.64 \\
162.54 \\
6.912 \\
2.7 \\
1.62 \\
2.052\end{array}$ & $\begin{array}{c}\text { Acceptable } \\
\text { Acceptable } \\
\text { Acceptable with Warning } \\
\text { Acceptable with Waming } \\
\text { Acceptable } \\
\text { Acceptable } \\
\text { Acceptable with Warning } \\
\text { Acceptable } \\
\text { Acceptable }\end{array}$ \\
\hline Sep99 & Water & $\begin{array}{c}\text { Cobalt-60 } \\
\text { Cesium-137 } \\
\text { Plutonium-238 } \\
\text { Plutonium-239 } \\
\text { Uranium-234 } \\
\text { Uranium-238 }\end{array}$ & $\begin{array}{l}1414.8 \\
2052 \\
21.33 \\
23.49 \\
9.99 \\
9.72 \\
\end{array}$ & $\begin{array}{c}1539 \\
2324.7 \\
18.09 \\
22.518 \\
10.584 \\
11.934 \\
\end{array}$ & $\begin{array}{c}\text { Acceptable } \\
\text { Acceptable } \\
\text { Acceptable with Warning } \\
\text { Acceptable } \\
\text { Acceptable } \\
\text { Acceptable with Warning }\end{array}$ \\
\hline Sep99 & Soil & Cesium-137 & 5508 & 5886 & Acceptable \\
\hline Sep99 & Vegetation & $\begin{array}{c}\text { Cobalt-60 } \\
\text { Cesium-137 }\end{array}$ & $\begin{array}{l}475.2 \\
11880\end{array}$ & $\begin{array}{l}477.9 \\
12636\end{array}$ & $\begin{array}{l}\text { Acceptable } \\
\text { Acceptable }\end{array}$ \\
\hline Sep99 & Air Filter & $\begin{array}{l}\text { Manganese-54 } \\
\text { Cobalt-57 } \\
\text { Cobalt-60 } \\
\text { Ruthenium-106 } \\
\text { Cesium-137 }\end{array}$ & $\begin{array}{c}213.57 \\
208.71 \\
171.45 \\
148.5 \\
173.61\end{array}$ & \begin{tabular}{|c|}
232.47 \\
207.63 \\
171.45 \\
144.45 \\
180.9
\end{tabular} & $\begin{array}{l}\text { Acceptable } \\
\text { Acceptable } \\
\text { Acceptable } \\
\text { Acceptable } \\
\text { Acceptable }\end{array}$ \\
\hline
\end{tabular}

NOTES: (1) Units are pCi/liter for water samples, $\mathrm{pCi} / \mathrm{kg}$ for soil and vegetation samples, and $\mathrm{pCi} /$ filter for air filter samples.

(2) The reported value is the result of a single determination.

(3) Acceptable performance indicates that the measurement fell between the 15th and 85th percentile. The acceptable with warning designation indicates that the measurement fell between the 5 th and 15 th percentiles or the 85th and 95th percentiles. The not acceptable designation is established at less than the 5th percentile and greater than the 95th percentile.

(4) Based on the plutonium analysis of other sample media, the March 1999 plutonium-in-water results were considered a statistical anomaly; the plutonium analysis system generates acceptable results. 